\title{
Environmental Site Description for a Uranium Atomic Vapor Laser Isotope Separation (U-AVLIS) Production Plant at the Oak Ridge Gaseous Diffusion Plant Site
}

Environmental Assessment and Information Sciences Division Argonne National Laboratory

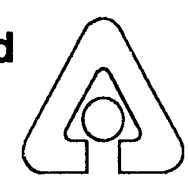

Operated by The University of Chicago, under Contract W-31-109-Eng-38, for the United States Department of Energy 


\section{Argonne National Laboratory}

Argonne National Laboratory, with facilities in the states of Illinois and Idaho, is owned by the United States government, and operated by the University of Chicago under the provisions of a contract with the Department of Energy.

This technical memo is a product of Argonne's Environmental Assessment and Information Sciences (EAIS) Division. For information on the division's scientific and engineering activities, contact:

Director, Environmental Assessment and

Information Sciences Division

Argonne National Laboratory

Argonne, Illinois 60439-4815

Telephone (708) 972-3759

Presented in this technical memo are preliminary results of ongoing work or work that is more limited in scope and depth than that described in formal reports issued by the EAIS Division.

\section{Disclaimer}

This report was prepared as an account of work sponsored by an agency of the United States Government. Neither the United States Government nor any agency thereof, nor any of their employees, makes any warranty, express or implied, or assumes any legal liability or responsibility for the accuracy, completeness, or usefulness of any information, apparatus, product, or process disclosed, or represents that its use would not infringe privately owned rights. Reference herein to any specific commercial product, process, or service by trade name, trademark, manufacturer, or otherwise, does not necessarily constitute or imply its endorsement, recommendation, or favoring by the United States Government or any agency thereof. The views and opinions of authors expressed herein do not necessarily state or reflect those of the United States Government or any agency thereof.

Reproduced from the best available copy. Available from the National Technical Information Service (NTIS), U.S. Department of Commerce, 5285 Port Royal Road, Springfield, Virginia 22161.

NTIS price codes:

Printed copy A05

Microfiche 


\section{Environmental Site Description for a Uranium Atomic Vapor Laser Isotope Separation (U-AVLIS) Production Plant at the Oak Ridge Gaseous Diffusion Plant Site}

Environmental Assessment and Information Sr:-nces Division, Argonne National Laboratory, 9700 South Cass Avenue, Argonne, Illinois 60439

Work sponsored by United States Department of Energy, Office of Nuclear Energy 


\section{Contents}

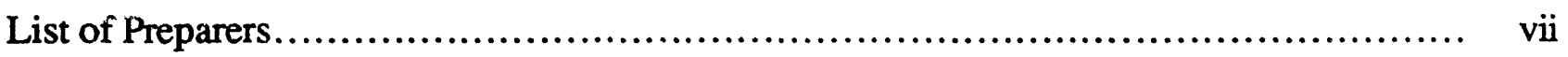

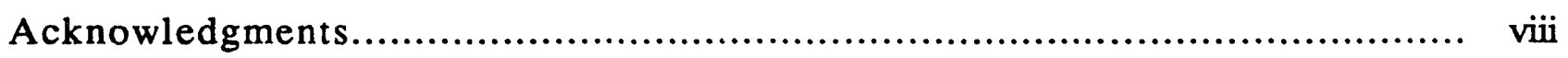

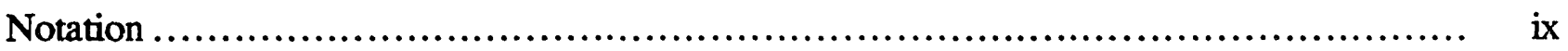

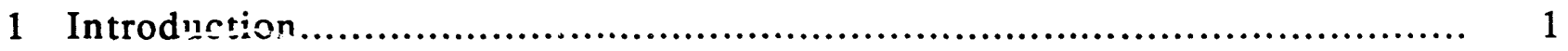

1.1 Context of this Document ................................................... 1

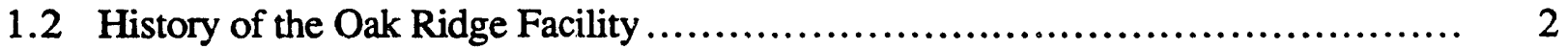

2 Affected Environment ............................................................. 4

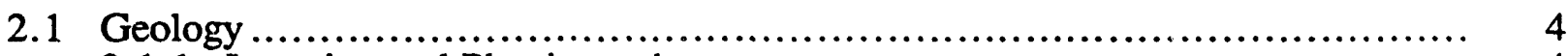

2.1.1 Location and Physiography ..............................................

2.1.2 Regional Geology ..................................................... 4

2.1.3 Local Geology .................................................... 11

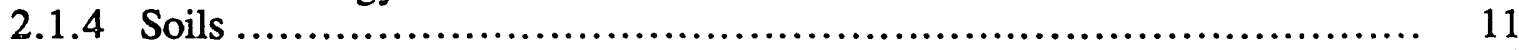

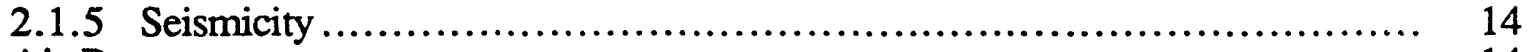

2.2 Air Resources.............................................................. 14

2.2.1 Climate and Local Meteorology ........................................ 14

2.2.2 Air Quality........................................................ 15

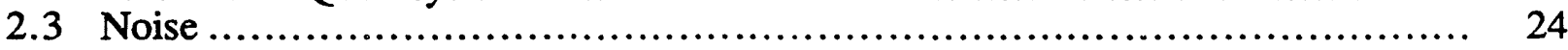

2.4 Water Resources.............................................................. 24

2.4.1 Regional Surface Water................................................ 24

2.4.2 Local Surface Water.................................................. 28

2.4.3 Regional Groundwater............................................ 30

2.4.4 Local Ground water.................................................... $\quad 30$

2.4.5 Water Regulations ................................................ 34

2.5 Land Use, Recreation, and Visual Resources................................. 34

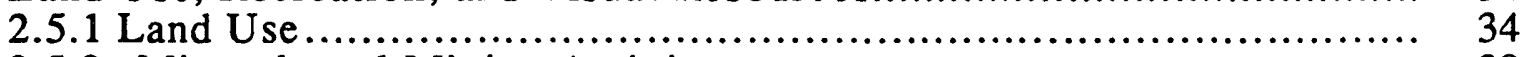

2.5.2 Minerals and Mining Activity ............................................. 38

2.5.3 Recreational Resources ........................................................ 38

2.5.4 Transportation Network ............................................. 39

2.5.5 Visual Resources ................................................. 41

2.6 Biotic Resources.......................................................... 42

2.6.1 Terrestrial Resources...................................................... 42

2.6.2 Wetlands ............................................................ 43

2.6.3 Aquatic Resources.................................................. 44

2.6.4 Threatened and Endangered Species...................................... 45

2.7 Cultural Resources......................................................... 45

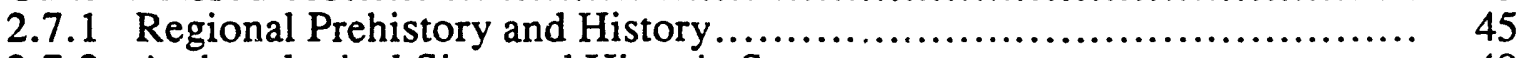

2.7.2 Archaeological Sites and Historic Structures ............................... 48

2.7.3 Native American Concerns ........................................... 49

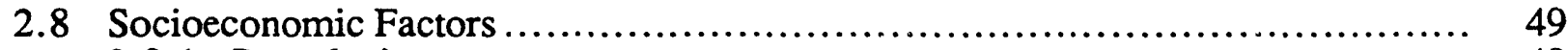

2.8.1 Population.......................................................................... 49

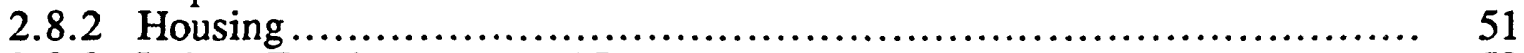

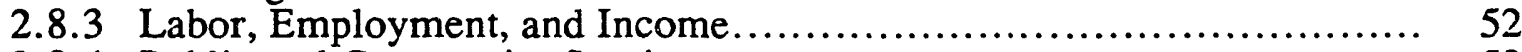

2.8.4 Public and Community Services ................................. 53 


\section{Contents (Cont'd)}

2.9 Waste Management........................................................ 57

2.9.1 Low-Level Radioactive Waste ..................................... 57

2.9.2 Hazardous Waste...................................................... 59

2.9 .3 Mixed Waste ............................................................ 60

2.9.4 Classified Waste............................................................ 60

2.9 .5 Toxic Waste ....................................................... 61

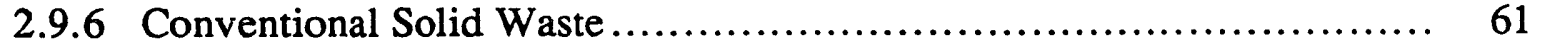

3 Additional Information Needs .............................................. 62

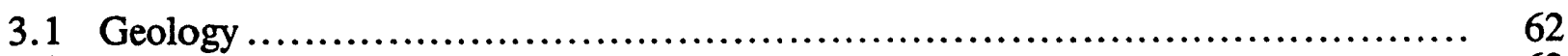

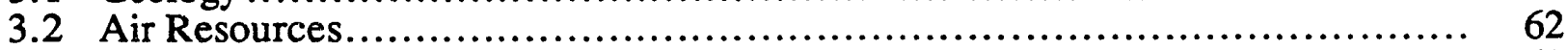

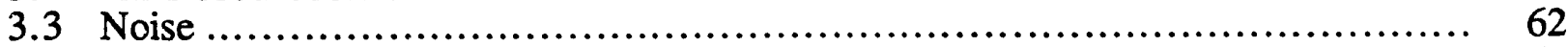

3.4 Water Resources............................................................ 62

3.5 Land Use, Recreation, and Visual Resources.............................. 63

3.6 Biotic Resources........................................................... 63

3.7 Cultural Resources ...................................................... 63

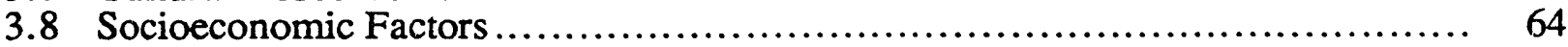

3.9 Waste Management..................................................... 64

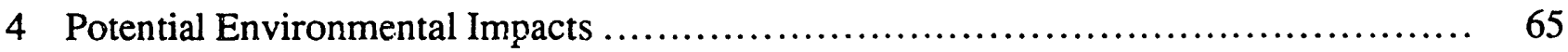

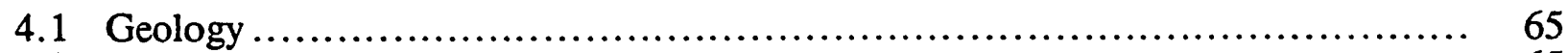

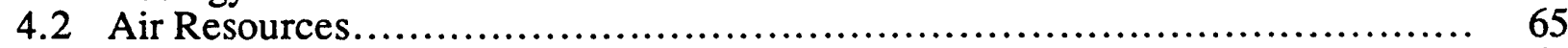

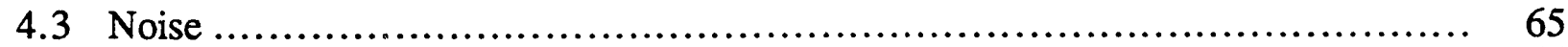

4.4 Water Resources.............................................................. 66

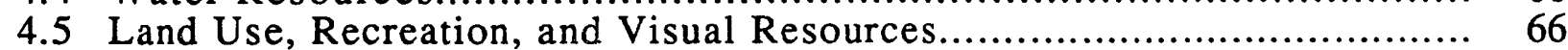

4.6 Biotic Resources.............................................................. 66

4.7 Cultural Resources ............................................................ 67

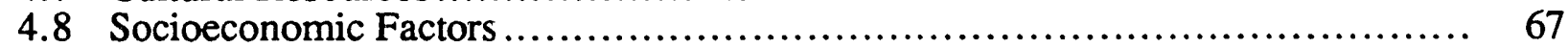

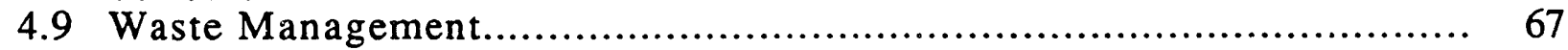

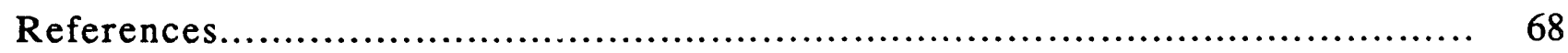

Appendix A: Species Occurring on the K-25 Site ............................... 71

Appendix B: National Register of Historic Places: Sites in Study Area............... 77

\section{Figures}

1 Locations of Three Alternative Sites for a U-AVLIS Production Plant............. 2

2 Location of the Oak Ridge Reservation in Eastern Tennessee ..................... 5

3 Location of the K-25 Site on the Oak Ridge Reservation ....................... 6

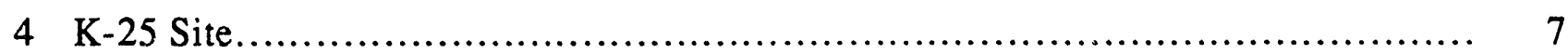




\section{Figures (Cont'd)}

5 Physiographic Location of the K-25 Site............................................... 8

6 Regional Geologic Map.............................................................. 9

7 Geologic Cross Section in the Region of the K-25 Site.......................... 10

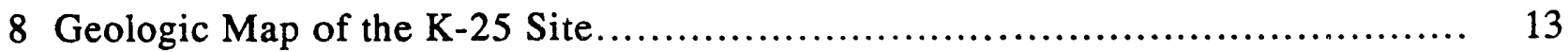

9 Wind Roses for 10-m and 60-m Levels of the Meteorological "K" Tower

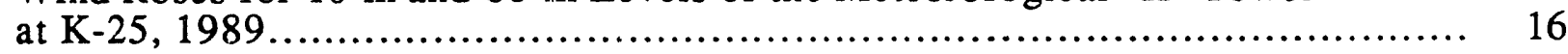

10 Locations of the Largest Air Pollution Sources at K-25 ............................... 19

11 Locations of 10 Ambient Air Monitoring Stations Operated by the ORR

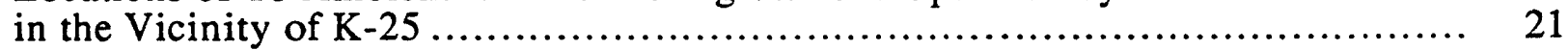

12 Locations of the External Monitoring Stations Operated by the State

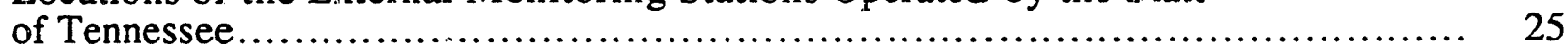

13 Major Surface Drainage in the Vicinity of K-25 ............................. 28

14 K-25 NPDES Discharge and Other Water-Monitoring Locations .................... 29

15 Contours of the Water Table and Inferred Groundwater Flow Paths in the

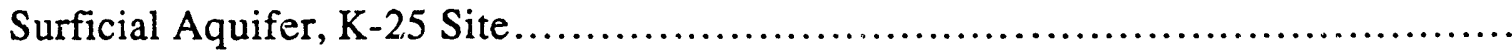

16 Contours of the Potentiometric Surface and Inferred Groundwater Flow Paths in the Bedrock Aquifer..................................................... 32

17 Location of the Groups of Solid Waste Management Units ....................... 33

$18 \mathrm{~K}-25$ Site and Proximity to Population Centers .................................. 35

19 Land Use in the Study Area...................................................... 37

20 Regional Transportation Network ......................................... 40

\section{Tables}

1 Generalized Geologic Section................................................. 12

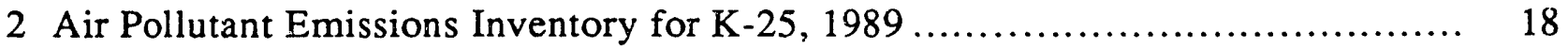

3 Ambient Moritoring Data for 1989 from the K1-K5 Air Monitors .................. 22

4 Ambient Monitoring Data for 1989 from the TSCA1 and TSCA2 Air Monitors 


\section{Tables (Cont'd)}

5 Comparison of 1990 Ambient Air Monitoring Data from Selected Stations of the Tennessee Monitoring Network with Tennessee

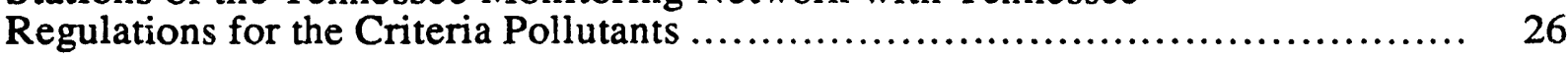

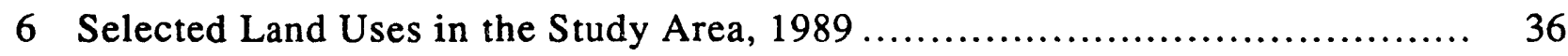

7 State Parks and Recreation Areas within the Study Area and Adjacent Counties.................................................................. 39

8 Mileage Total, by Road Type, for Each Study-Area County.................... 41

9 Threatened, Endangered, or Special-Interest Species that Occur or

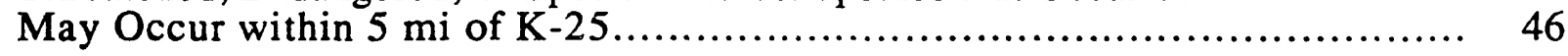

10 Current and Historical Population Data for the Study Area........................ 50

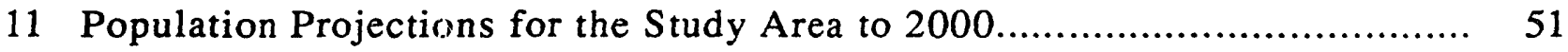

12 Housing Units in the Five-County Area and Apartment Vacancy Status, 1990 .

13 Employment and Income in the Study Area..................................... 53

14 County Public School Statistics for the Study Area, Scholastic Year 1989....... 54

15 Medical Resources in the Study Area, 1988-1990 ........................... 56

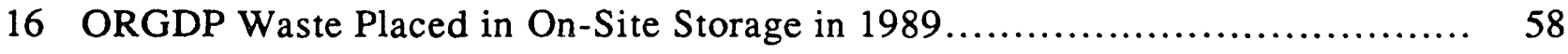

17 Waste Placed in Storage at K-25 from Other DOE Facilities during 1989......... 59

18 K-25 Off-Site Waste Disposal Activities during 1989......................... 60

A.1 Names of K-25 Species, Other than Threatened and Endangered Species 


\section{List of Preparers}

Name

Gary J. Marmer

Christopher P. Dunn

Thomas H. Filley

Lynn M. Malinowski

Konstance L. Moeller

John M. Pfingston

Anthony J. Policastro

John H. Cleland

\section{Equcation/Expertise}

Ph.D. Physics

18 years experience in environmental assessment

Ph.D. Ecology

13 years experience in ecological research and environmenial assessment

Ph.D. Hydrogeology

6 years experience in groundwater research and environmental assessment

M.A. Anthropology

4 years experience in environmental assessment

M.A. Anthropology

3 years experience in cultural resources assessinent

M.P.A. Environmental Administration 3 years experience in energy and natural resource administration and analysis

\section{Ph.D. Civil Engineering}

20 years experience modeling environmental transport processes in the air and water

M.A. English 15 years experience editing engineering and scientific materials
Project Manager, Waste Management

Biotic Resources

Geology,

Water Resources

Cultural Resources

Cultural Resources

Land Use, Socioeconomics

Air Resources, Noise

Editing, coordinating production 


\section{Acknowledgments}

The preparers of this environmental site description thank many people for their contributions in helping gather the needed information, in reviewing the document during its draft stages and guiding its development, and in providing production assistance of various kinds.

We thank Margaret Greaney of Argonne National Laboratory and her staff -- Lia Avolio, Karen Brandeis, Brenda Koebnick, and Julius Mitchell -- for preparing and revising most of the figures.

Text processing was coordinated by Barbara Salbego and performed by her, Judith Robson, and Lorenza Ceballos of Argonne. Annette Edler and Laura Schmidt of the Argonne staff assembled review drafts of the document.

W. Sedgfield White, David Dashevsky, and Arnold Litman of the U.S. Department of Energy provided valuable reviews and guidance throughout the preparation of the document.

We acknowledge the assistance of John Cleaves of Martin Marietta Energy Systems, Inc. He and his staff at the Oak Ridge Gaseous Diffusion Plant assisted the Argorine preparers in gathering the data needed for this document. Finally, William Vinikour of Argonne assisted in the initial stages of gathering the ecological data. 


\section{Notation}

\section{Acronyms, Initialisms, and Chemical Names}

$\begin{array}{ll}\text { AEC } & \text { Atomic Energy Commission } \\ \text { ANL } & \text { Argonne National Laboratory } \\ \text { CBER } & \text { Center for Business and Economic Research } \\ \text { CDR } & \text { Conceptual Design Report } \\ \text { DOE } & \text { U.S. Department of Energy } \\ \text { EIS } & \text { environmental impact statement } \\ \text { EPA } & \text { U.S. Environmental Protection Agency } \\ \text { ERDA } & \text { Energy Research and Development Administration } \\ \text { ESD } & \text { environmental site description } \\ \text { ETDD } & \text { East Tennessee Development District } \\ \text { ETNGC } & \text { East Tennessee Natural Gas Co. } \\ \text { HF } & \text { hydrogen fluoride } \\ \text { KCPRD } & \text { Knox County Parks and Recreation Department } \\ \text { KKCMPC } & \text { Knoxville-Knox County Metropolitan Planning Commission } \\ \text { LCUB } & \text { Loudon County Utility Board } \\ \text { MCL } & \text { maximum contaminant level } \\ \text { MED } & \text { Manhattan Engineer District } \\ \text { MSL } & \text { mean sea level } \\ \text { NESHAP } & \text { National Emissions Standards for Hazardous Air Pollutants } \\ \text { NPDES } & \text { National Pollutant Discharge Elimination System } \\ \text { NRHP } & \text { National Register of Historic Places } \\ \text { ORGDP } & \text { Oak Ridge Gaseous Diffusion Plant } \\ \text { ORNL } & \text { Oak Ridge National Laboratory } \\ \text { ORR } & \text { Oak Ridge Reservation } \\ \text { OVEC } & \text { Ohio Valley Electric Corp. } \\ \text { OVRDC } & \text { Ohio Valley Regional Development Commission } \\ \text { PAM } & \text { perimeter air monitoring (station) } \\ \text { PCB } & \text { polychlorinated biphenyl } \\ \text { PGA } & \text { peak ground acceleration } \\ \text { PGDP } & \text { Paducah Gaseous Diffusion Plant } \\ \text { PM } 10 & \text { particulate matter less than 10 microns in diameter } \\ \text { PMC } & \text { Project Management Corp. } \\ \text { PORTS } & \text { Portsmouth Gaseous Diffusion Plant } \\ \text { PSD } & \text { Prevention of Significant Deterioration } \\ \text { RCRA } & \text { Resource Conservation and Recovery Act } \\ \text { SARA } & \text { Superfund Amendments and Reauthorization Act } \\ \text { SWMU } & \text { solid waste management unit } \\ \text { TDC } & \text { Tennessee Department of Conservation } \\ \text { TDG } & \text { Tennessee Division of Geology } \\ \text { TDHE } & \text { Tennessee Department of Health and Environment } \\ \text { TDS } & \text { total dissolved solids } \\ & \end{array}$


TSCA Toxic Substances Control Act

TSP total suspended particulates

TVA Tennessee Valley Authority

TWRA Tennessee Wildlife Resources Agency

U-AVLIS Uranium Atomic Vapor Laser Isotope Separation

$\mathrm{UF}_{6} \quad$ uranium hexafluoride

USBC U.S. Bureau of the Census

USDOE U.S. Department of Energy

\section{Units of Measure}

$\begin{array}{ll}{ }^{\circ} \mathrm{C} & \text { degrees Centigrade } \\ \mathrm{cfs} & \text { cubic feet per second } \\ \mathrm{dBA} & \text { A-weighted decibul(s) } \\ \mathrm{O}_{\mathrm{F}} & \text { degrees Fahrenheit } \\ \mathrm{ft} & \text { foot (feet) } \\ \mathrm{ft} / \mathrm{min} & \text { feet per minute } \\ \mathrm{g} & \text { acceleration of gravity } \\ \mathrm{g} & \text { gram(s) } \\ \mathrm{h} & \text { hour(s) } \\ \mathrm{Hz} & \text { hertz } \\ \mathrm{I} \mathrm{MM} & \text { modified Mercalli (seismic) intensity } \\ \mathrm{kg} & \text { kilogram(s) } \\ \mathrm{kHz} & \text { kilohertz } \\ \mathrm{km} & \text { kilometer(s) } \\ \mathrm{L} & \text { liter(s) } \\ \mathrm{lb} & \text { pound(s) } \\ \mathrm{m} & \text { meter(s) } \\ \mathrm{mb} & \text { (seismic) magnitude } \\ \mu \mathrm{Ci} & \text { microcurie(s) } \\ \mu \mathrm{Ci} / \mathrm{yr} & \text { microcuries per year } \\ \mu \mathrm{g} / \mathrm{m}^{3} & \text { micrograms per cubic meter } \\ \mathrm{mg} / \mathrm{L} & \text { milligrams per liter } \\ \mathrm{mgd} & \text { mi!lion gallons per day } \\ \mathrm{mi} & \text { mile(s) } \\ \mathrm{mi} 2 & \text { square mile(s) } \\ \mathrm{MW} & \text { megawatt(s) } \\ \mathrm{ng} / \mathrm{m}^{3} & \text { nanograms per cubic meter } \\ \mathrm{pCi} / \mathrm{m}^{3} & \text { picocuries per cubic meter } \\ \mathrm{pg} / \mathrm{m}^{3} & \text { picograms per cubic meter } \\ \mathrm{yr} & \text { year(s) } \\ & \end{array}$




\section{Environmental Site Description for a Uranium Atomic Vapor Laser Isotope Separation (U-AVLIS) Production Plant at the Oak Ridge Gaseous Diffusion Plant (K-25) Site}

\section{Introduction}

\subsection{Context of this Document}

Uranium enrichment in the United States has utilized a diffusion process to preferentially enrich the U-235 isotope in the uranium product. In the 1970s, the U.S. Department of Energy (DOE) began investigating more efficient and cost-effective enrichment technologies. In January 1990, the Secretary of Energy approved a plan for the demonstration and deployment of the Uranium Atomic Vapor Laser Isotope Separation (U-AVLIS) technology, with the near-term goal to provide the necessary information to make a deployment decision by November 1992. Initial facility operation is anticipated for 1999.

The U-AVLIS process is based on electrostatic extraction of photoionized U-235 atoms from an atomic vapor stream created by electron-beam vaporization of uranium metal alloy. The U-235 atoms are ionized when precisely tuned laser light -- of appropriate power, spectral, and temporal characteristics -- illuminates the uranium vapor and selectively photoionizes the U-235 isotope. The electron energy states of each uranium isotope are unique, and isotopic enrichment exploits the small spectral shift in the absorptivity of the different uranium isotopes. The enriched uranium product is collected on negatively charged product collector plates, and depleted uranium is collected on a neutral surface. During U-AVLIS enrichment, a feedstock of approximately $0.7 \%$ $\mathrm{U}-235$ isotopic assay is converted to a product of $3-5 \% \mathrm{U}-235$ isotopic assay.

A programmatic document for use in screening DOE sites to locate the U-AVLIS production plant was developed and implemented in two parts (Wolsko et al. 1991). The first part consisted of a series of screening analyses, based on exclusionary and other criteria, that identified a reasonable number of candidate sites. These sites were then subjected to a more rigorous and detailed comparative analysis for the purpose of developing a short list of reasonable alternative sites for later environmental examination. The final evaluation, which included sensitivity studies, identified the Oak Ridge Gaseous Diffusion Plant (ORGDP) site, also known as the K-25 site; the Paducah Gaseous Diffusion Plant (PGDP) site; and the Portsmouth Gaseous Diffusion Plant (PORTS) site as having significant advantages over the other sites considered.

On April 10, 1991, the DOE announced the results of the final programmatic study. The locations of the three sites just identified are shown in Fig. 1.

This environmental site description (ESD) provides a detailed description of the ORGDP site and vicinity suitable for use in an environmental impact statement (EIS). The report is based on existing literature, data collected at the site, and information collected by Argonne National Laboratory (ANL) staff during a site visit. 


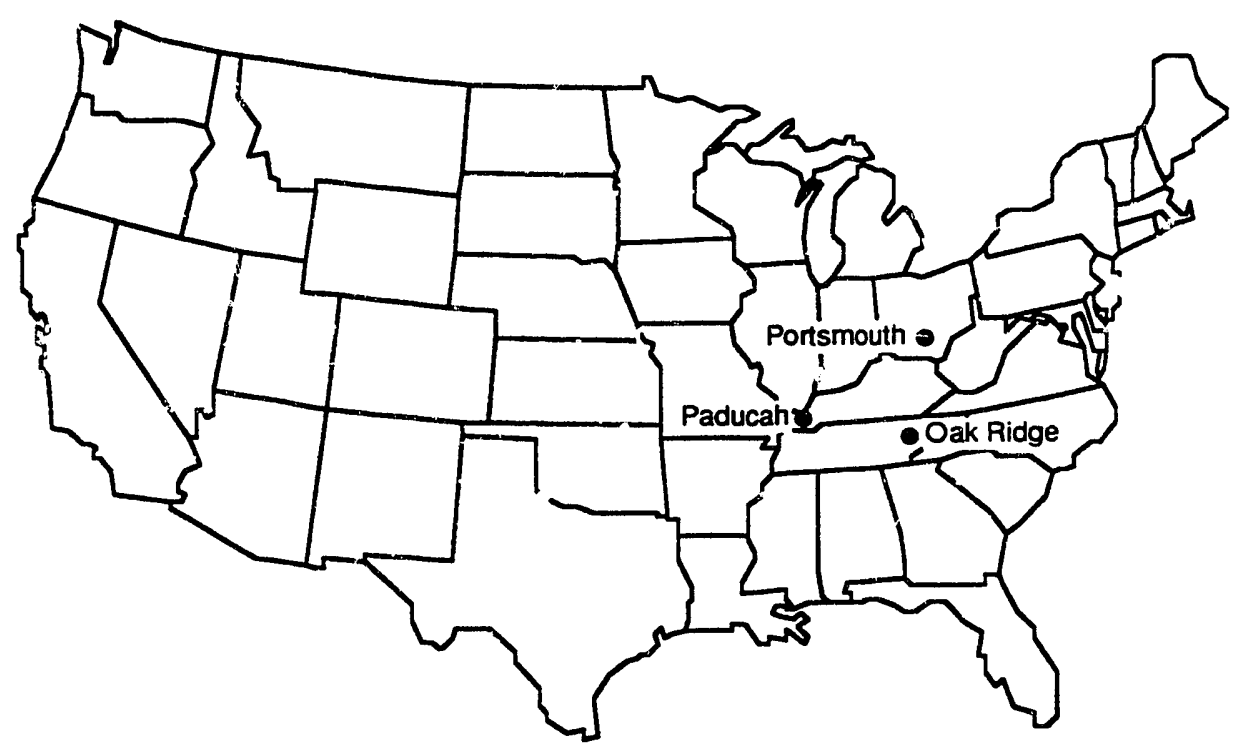

FIGURE 1 Locations of Three Alternative Sites for a U-AVLIS Production Plant

The organization of the ESD is as follows. Topics addressed in Sec. 2 include a general site description and the disciplines of geology, water resources, biotic resources, air resources, noise, cultural resources, land use, socioeconomics, and waste management. Identification of any additional data that would be required for an EIS is presented in Sec. 3.

Following the site description and additional data requirements, Sec. 4 provides a short, qualitative assessment of potential environmental issues. These issues are based on best available knowledge of the conceptual design as presented in the site data package (Martin Marietta 1990). The brief assessments relate to constructing and operating a U-AVLIS production plant.

This document was prepared even though details of the conceptual design of the U-AVLIS facility are not yet available. The absence of these details, which will be provided at a future date in the Conceptual Design Report (CDR), is not expected to greatly affect the descriptions presented here. Such information will be necessitated, however, for the comprehensive environmental analysis required in an EIS.

\subsection{History of the Oak Ridge Facility}

Before World War II, the area that presently contains the Oak Ridge Reservation (ORR) and the city of Oak Ridge consisted of forest land, scattered farms, and small communities. The U.S. entry into the war in late 1941 precipitated a massive national effort to develop a nuclear weapon. To construct the weapon, the U.S. Army's Manhattan Engineer District (MED) was assembled from the ranks of prominent scientists and engineers. In September 1942, a 90-square mile $\left(\mathrm{mi}^{2}\right)$ tract of land straddling Roane and Anderson counties in the gently rolling hills of eastern Tennessee was chosen by the MED for large-scale uranium enrichment facilities and a nuclear reactor prototype critical to the weapon's development (AEC 1972). The site was located in an area of sparse population (reduced risk and tighter security) close to the Clinch River, and the new 
industrial operations drew on the labor base and transportation network of nearby Knoxville. Electrical power for the project was provided by the Tennessee Valley Authority (TVA). Construction of housing and community facilities for the expected population influx, as well as a headquarters facility for the MED, was begun immediately.

In February 1943, after the MED had relocated 1,000 families and completely secured the perimeter of the ORR (originally called the Clinton Engineer Works), construction of the Y-12 electromagnetic separation process facility began. The $\mathrm{Y}-12$ facility was located in the eastern sector of ORR, a few miles south of the city of Oak Ridge. At the same time, a few miles west of the Y-12 site, construction began on in X-10 prntotype reactor, which would serve as a pilot plant for the iarge-scale plutonium production plant under construction at the same time in Hanford, Washington (Jackson and Johnson 1981). Oak Ridge National Laboratory (ORNL) developed around the X-10 site. Construction at the K-25 site, which would contain a plant utilizing a gaseous diffusion enrichment process, began in September 1943. The Union Carbide Corp. (then called the Carbide and Chemicals Co.) was awarded the contract to operate the ORGDP in January 1943.

By 1945, the population of Oak Ridge, which was entirely surrounded by security fences, had reached 75,000. When the war ended in September 1945, the ORR employed 82,000 people. In 1947, the Atomic Energy Commission (AEC) took control of the ORR, but community sectors remained off-limits to the general public until 1949. In 1955, Congress passed legislation allowing the AEC to sell almost 12,000 parcels of land for residential and commercial uses. The city of Oak Ridge was officially incorporated in 1959 and included most of the ORR within its boundaries. The population of Oak Ridge rapidly declined after the war, to a low of 27,169 in 1960.

Administration of the ORGDP was turned over to Martin Marietta Energy Systems, Inc., in 1984. In June 1985, operations at the ORGDP were suspended. 


\section{Affected Environment}

This section describes the environment of the K-25, or ORGDP, site that could be affected by the siting, construction, and operation of a U-AVLIS production plant. The ORR is a 35,252-acre DOE facility in eastern Tennessee (Fig. 2). The K-25 site is located on the ORR and within the corporate limits of the city of Oak Ridge immediately east of the Clinch River in Roane County (Fig. 3).

The K-25 site consists of 1,700 acres of land, of which more than 70G acres are fenced, and was originally operated as a uranium enrichment facility (Fig. 4). The ORGDP was shut down in 1985, and the site is now primarily involved with waste management activities, advanced enrichment technologies, analytical laboratory services, and engineering and computer support.

The proposed U-AVLIS site is located in an undeveloped, wooded area on the east end of the K-25 site near the intersection of the Oak Ridge Turnpike and Blair Road.

\subsection{Geology}

\subsubsection{Location and Physiography}

Regionally, Roane County exists within the Valley and Ridge physiographic province of the Appalachian Highlands region (Fig. 5). The Valley and Ridge province is characterized by elongated ridges and valleys that trend northeast to southwest from New York to Alabama. In the vicinity of $\mathrm{K}-25$, the Valley and Ridge province is bounded on the west by the Cumberland Plateau and on the east by the Unicoi and Great Smoky Mountains. Ridge tops near the K-25 site have a fairly uniform elevation of 1.000 to 1,100 feet ( $\mathrm{ft}$ ) above mean sea level (MSL); valleys are approximately $800 \mathrm{ft}$ MSL. The maximum relief in the immediate vicinity of K-25 is $420 \mathrm{ft}$, from the Clinch River to the top of McKinney Ridge. The present-day landforms in the K-25 area have resulted from differential erosion; ridges consist of resistant sandstones, shales, and dolostones, and valleys typically contain carbonate-rich rocks.

\subsubsection{Regional Geology}

Figure 6 is a geologic map of the vicinity of the ORR. As shown in this figure, the major structural elements of the region include several thrust faults that trend northeast-southwest along the axis of the valleys. The K-25 site itself is located on the White Oak Mountain fault. Figure 7 is a geologic cross section taken through the ORR. As shown in this figure, the geology is strongly influenced by complex structural elements. These structural features include regional and local thrust faults, tear faults, local folding, and widespread fracture development (Kornegay et al. 1990). The thick sequence of shale, sandstone, and limestone illustrated in Fig. 7 was deposited during the Paleozoic Era (Saylor et al. 1990). These rocks were subsequently faulted and folded 


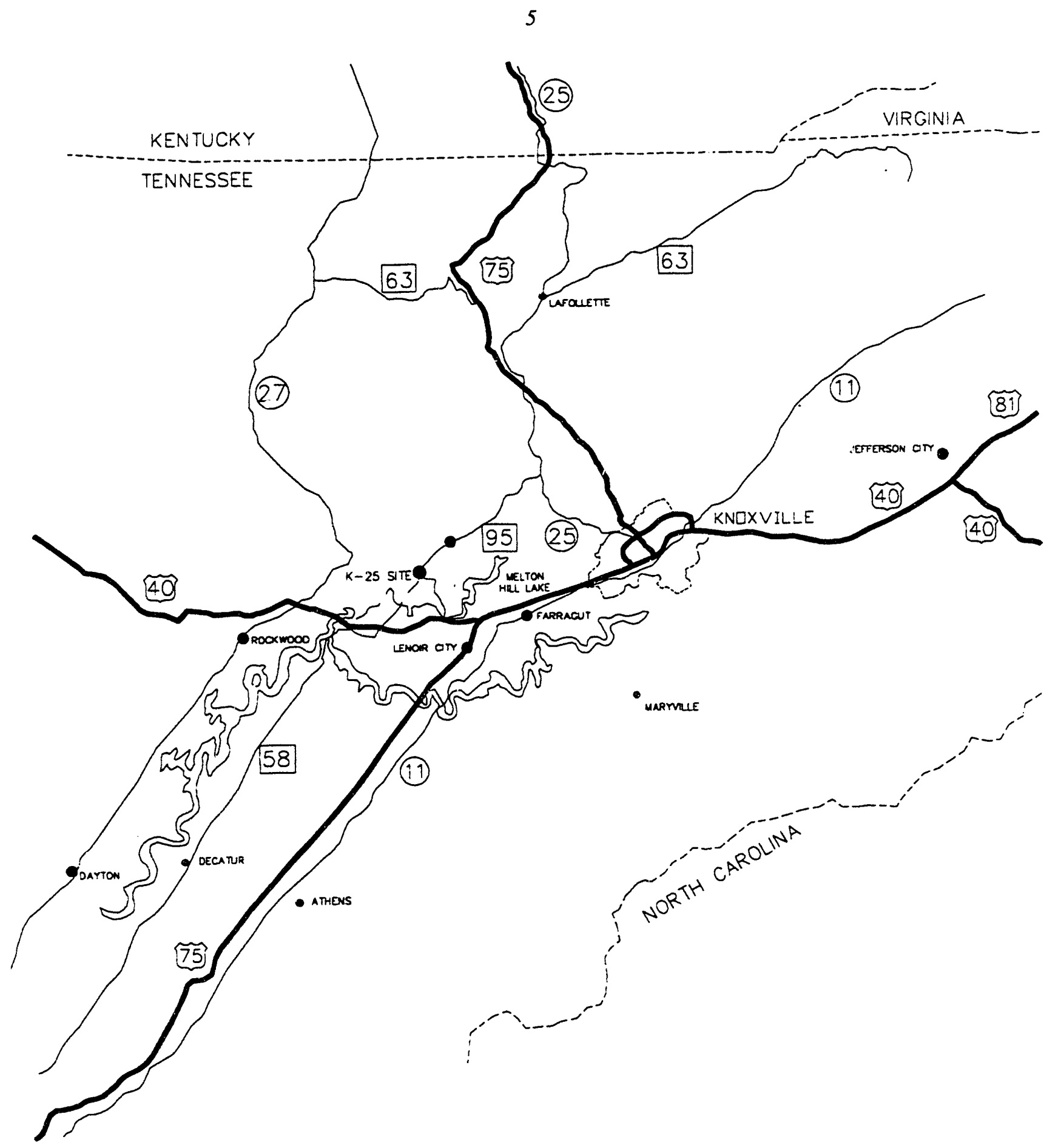

FIGURE 2 Location of the Oak Ridge Reservation in Eastem Tennessee 


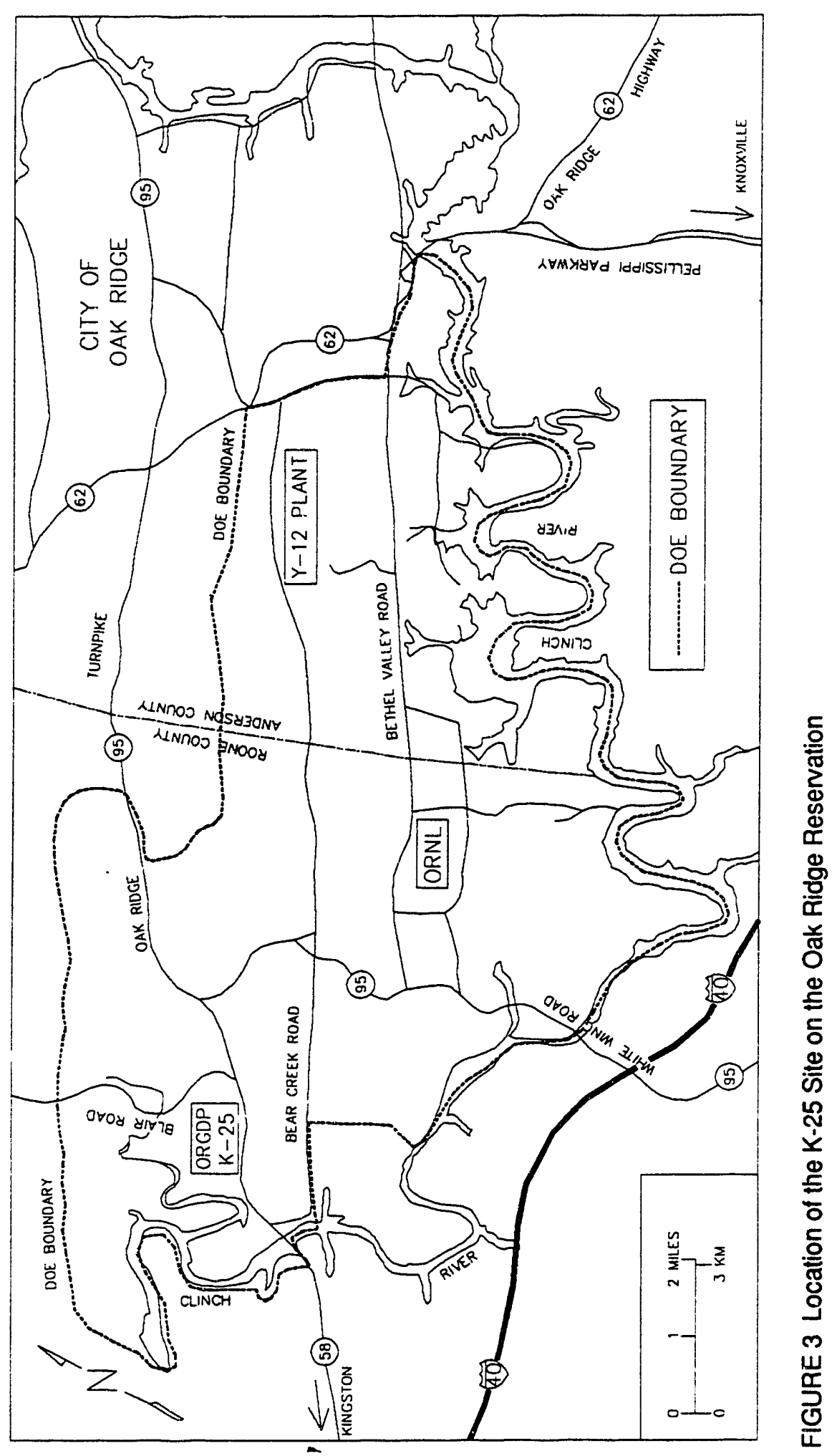




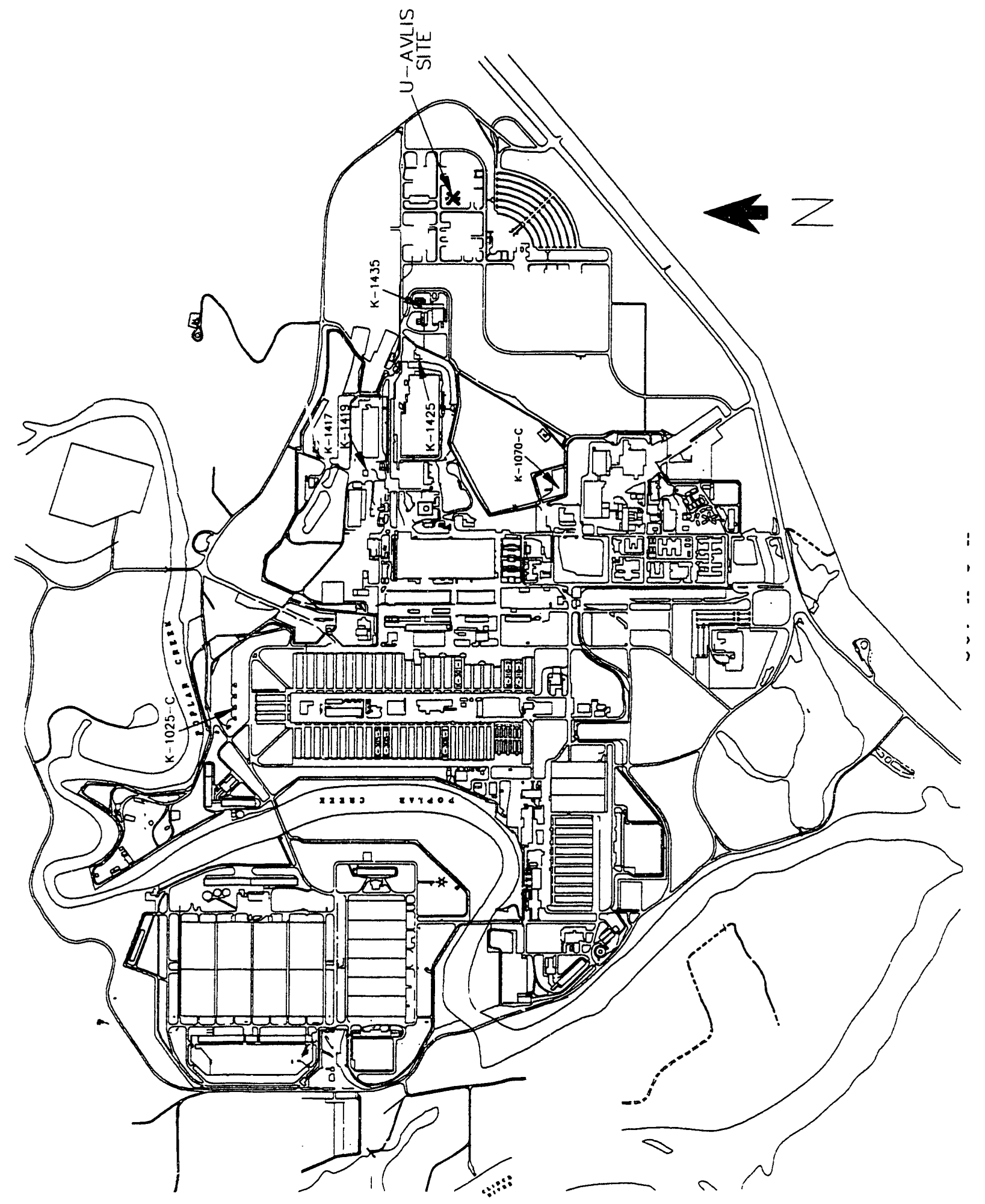

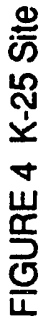




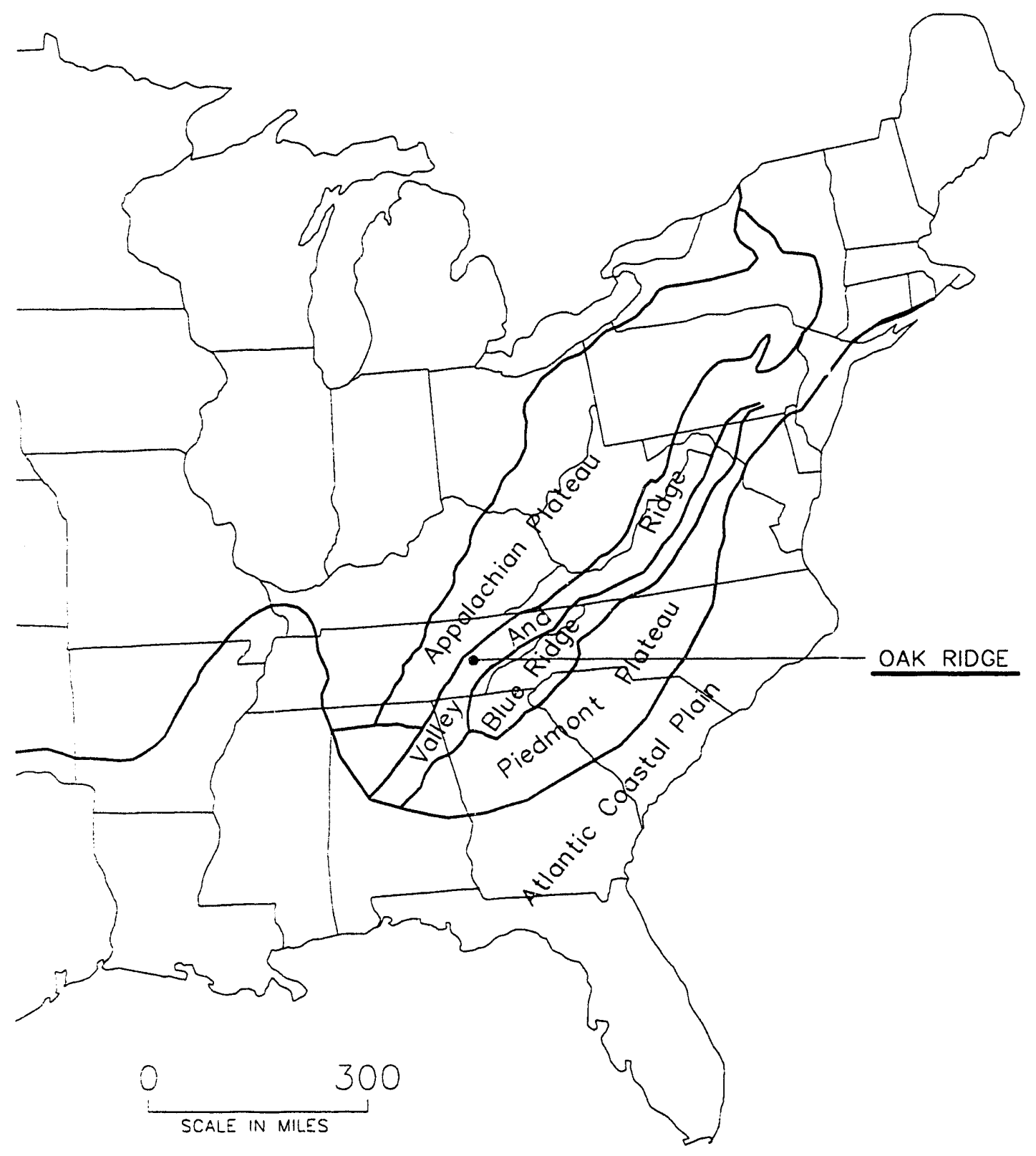

FIGURE 5 Physiographic Location of the K-25 Site 


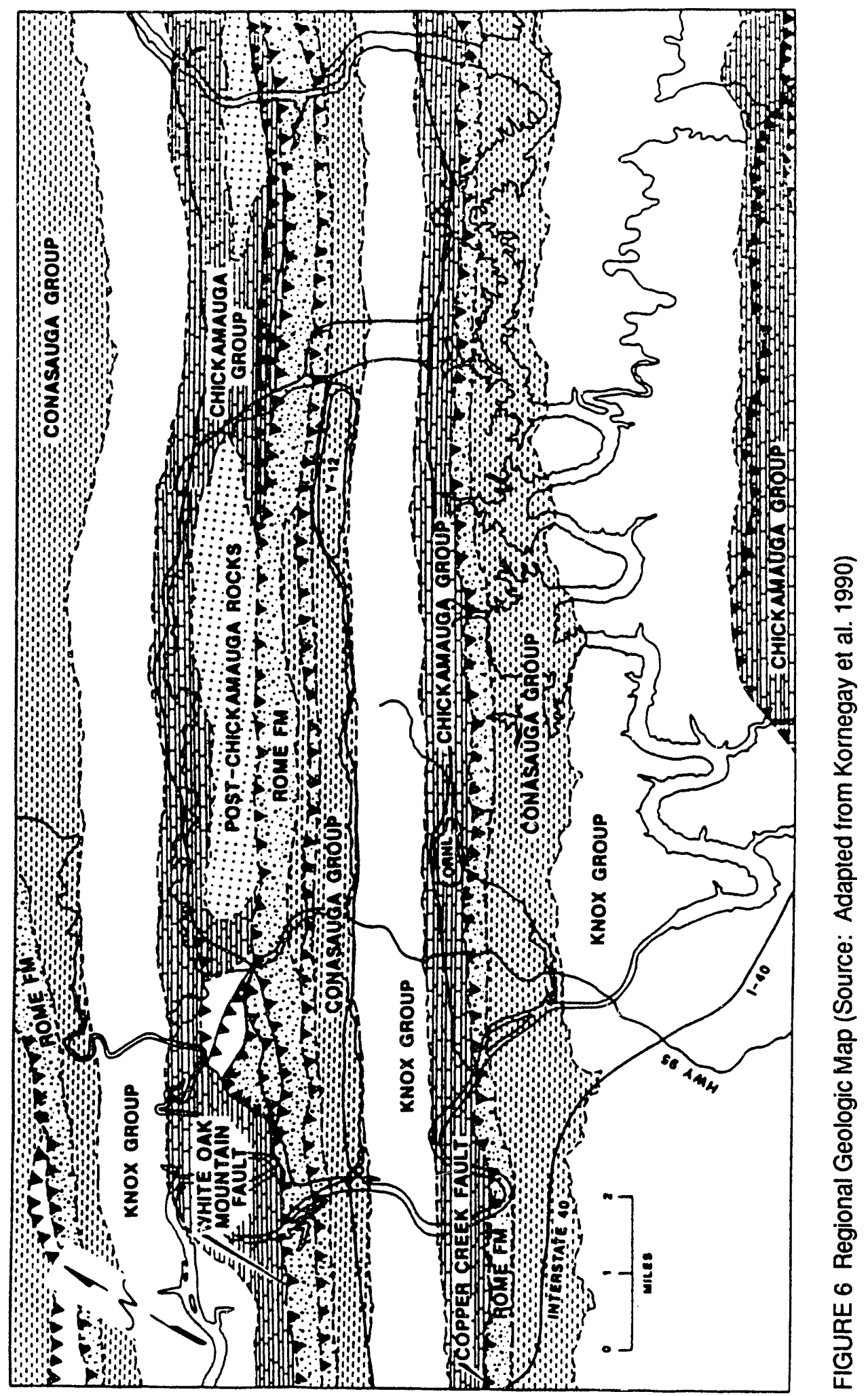




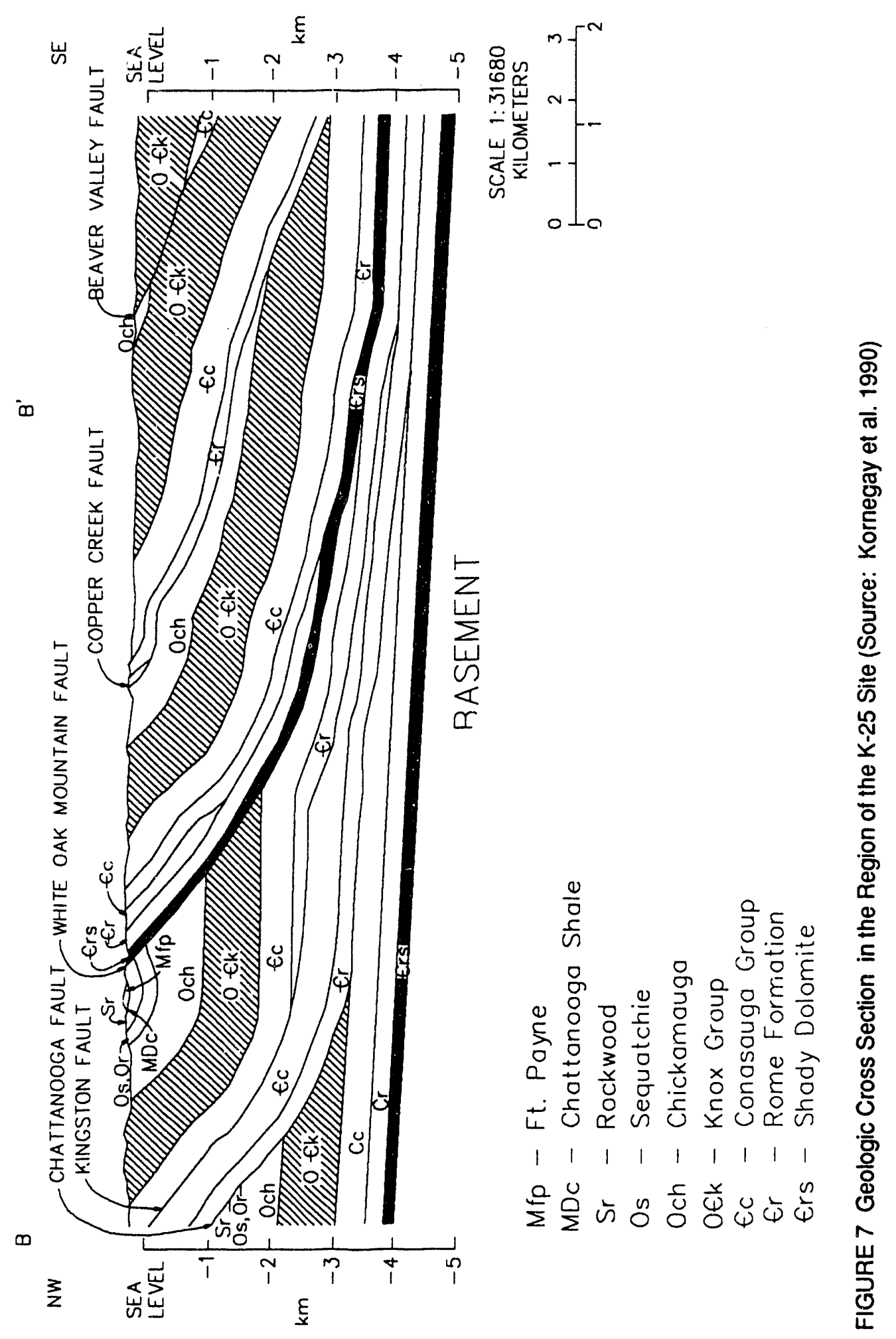


by the Alleghenian orogeny, which occurred during the late Paleozoic. A generalized stratigraphic column is presented in Table 1 . In it can be seen the Paleozoic sequence and typical thicknesses for the various formations. A more detailed description of the stratigraphy for the region miay be found in Saylor et al. (1990).

\subsubsection{Local Geology}

Figuie 8 shows the prominent geologic features in the vicinity of the K-25 site. The geology of the K-25 area is structurally very complex (Saylor et al. 1990). The dominant structural feature at K-25 is the Whiteoak Mountain Thrust fault, which trends northeasterly across the southern area of the site. The sedimentary units of interest at K-25 are, in ascending order, Shady Dolomite, Rome Formation, Conasauga Group, Knox Group, and Chickamauga Group.

The Shady Dolomite at K-25 is described as a white, gray to light yellowish gray dolostone and magnesian limestone. Its complete thickness at K-25 is obscured because of heavy faulting. The Rome Formation at K-25 is approximately $300 \mathrm{ft}$ to $400 \mathrm{ft}$ thick. The Rome Formation is predominantly a maroon to gray-green siltstone and shale, with fine-grained sandstones and zones of impure dark-colored dolostone and magnesian limestone (Saylor et al. 1990). The Conasauga Group is approximately $1,700 \mathrm{ft}$ thick and is formed by gray, olive, and brown limestone and siltstone. It consists, in ascending order, of Pumpkin Valley Shale, Rutledge Limestone, Rogersville Shale, Marysville Shale, Nolichucky Shale, and Maynardville Limestone. The Knox Group is described as a light to dark gray dolostone and dolomitic limestone, which can range from 2,000 $\mathrm{ft}$ to $3,000 \mathrm{ft}$ in thickness. It comprises five formations. These formations are, in ascending order, Copper Ridge Dolomite, Chepultepec Dolomite, Longview Dolomite, Kingsport Formation, and Mascot Dolomite. The Chickamauga Formation consists mostly of gray, partly maroon limestone, shaly limestone, calcareous siltstone, and shale, with chert zones in the lower units. The Chickamauga Group is divided into 10 formations, which are, in ascending order, Blackford, Five Oaks, Holston, Lincolnshire, Rockdell, Benbolt, Wardell, Bowen, Witten, and Moccasin.

\subsubsection{Soils}

The majority of the soils found at K-25 are residual (formed in place on a rock substrate) or, to a lesser extent, derived from alluvium (water-transported sediment). The alluvial soils occur in the floodplains of the K-25 site and are described as being a conglomerate of organic and mineral particles (Petrich et al. 1984). In addition to alluvial soil, other soils may form in the valleys of K-25. These valley soils are generally shallow (ranging from 15 to $30 \mathrm{ft}$ to refusal) and formed from a mixture of clay, silt, and weathered shale. Residual soils found on the ridges consist primarily of deep (up to $90 \mathrm{ft}$ ) well drained, fine-grained reddish clays. Soils at K-25 are not expansive, subject to liquefaction, or unstable. Martin Marietta (1990) describes some engineering properties of soils found at K-25. 
TABLE 1 Generalized Geologic Section

\begin{tabular}{|c|c|c|c|c|}
\hline Period & Group & Formation & $\begin{array}{l}\text { Thickness } \\
\text { (ft) }\end{array}$ & Characteristics of Rocks \\
\hline Mississippian & & Ft. Payne & 80 & $\begin{array}{l}\text { Impure limestone and } \\
\text { calcareous silistone, with } \\
\text { abundant chert }\end{array}$ \\
\hline Devonian & & $\begin{array}{l}\text { Chattanooga } \\
\text { Shale }\end{array}$ & 25 & Shalo, black, fissile \\
\hline Silurian & & Rockwood & 700 & $\begin{array}{l}\text { Siltstone, sandstone, and } \\
\text { shale; yellow to tan and brown }\end{array}$ \\
\hline \multirow[t]{3}{*}{ Ordovician } & & Sequatchie & 300 & $\begin{array}{l}\text { Shale, shaly limestone, sandy } \\
\text { shale, calcareous; maroon to } \\
\text { gray olive }\end{array}$ \\
\hline & Chickamauga & & 2,000 & $\begin{array}{l}\text { Limestone, shaly limestone, } \\
\text { calcareous siltstone, and shale; } \\
\text { mostly gray, partly maroon; with } \\
\text { cherty zones in lower units }\end{array}$ \\
\hline & Knox & $\begin{array}{l}\text { Mascot } \\
\text { Kingsport } \\
\text { Longview } \\
\text { Chepultepec } \\
\text { Copper Ridge }\end{array}$ & 3,000 & $\begin{array}{l}\text { Dolostone and dolomitic } \\
\text { limestone; light to dark gray; } \\
\text { with prominent chert zones }\end{array}$ \\
\hline \multirow[t]{3}{*}{ Cambrian } & Conasauga & \begin{tabular}{l|} 
Maynardville \\
Nolichucky \\
Maryville \\
Rogersville \\
Rutledge \\
Pumpkin Valley
\end{tabular} & 1,800 & $\begin{array}{l}\text { Limestone, siltstone, and shale; } \\
\text { gray, olive brown }\end{array}$ \\
\hline & & $\begin{array}{l}\text { Rome } \\
\text { Formation }\end{array}$ & $800+$ & $\begin{array}{l}\text { Sandstone and shale with } \\
\text { dolomitic limestone lenses; } \\
\text { variegated with yellow, brown, } \\
\text { red, maroon, and olive-green }\end{array}$ \\
\hline & & Shady Dolomite & $?$ & $\begin{array}{l}\text { Dolostone; cherty; numerous } \\
\text { vugs and fractures }\end{array}$ \\
\hline
\end{tabular}

Source: Kornegay et al. 1990. 


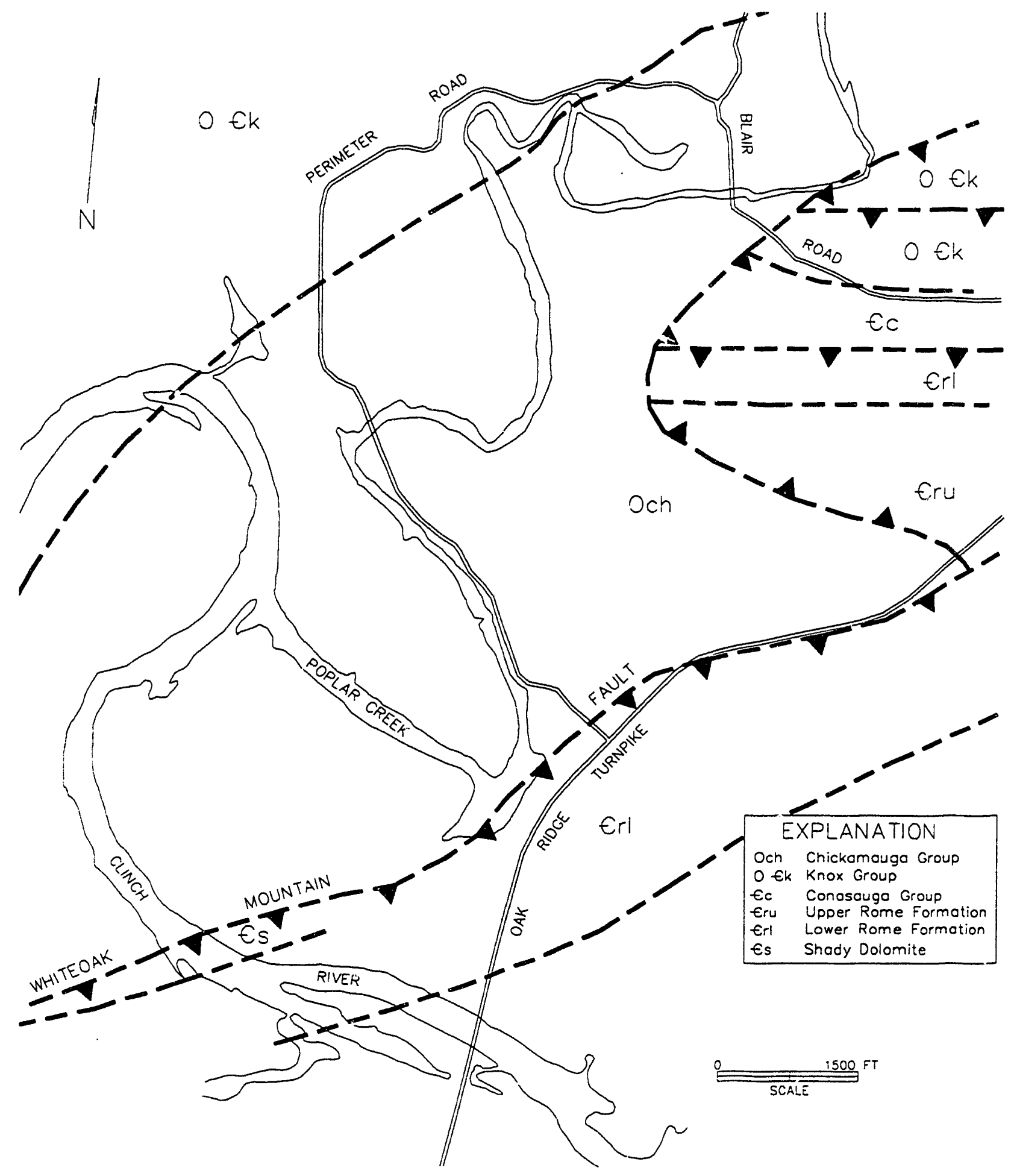

FIGURE 8 Geologic Map of the K-25 Site 


\subsubsection{Seismicity}

The K-25 site is located within a region characterized by heavy faulting (Saylor et al. 1990). Although these faults have not bee: examined in detail for recent movement, no correlation between them and historical seismicity can be made. The K-25 facility falls in the Southern Appalachian seismic source zone. The largest recorded earthquake in this seismic source zone occurred in Giles County, Virginia, on May 31, 1897, and registered a magnitude and modified Mercalli intensity of $m_{b}=5.8$ and $I_{M M}=$ VIII, respectively. The event was 217 miles (mi) from Oak Ridge, and the intensity, at such a distance, was far below the level at which damage might be expected to occur (Saylor et al. 1990). Mean 1,000-year (yr) peak ground acceleration (PGA) estimates for the K-25 site range from 0.12 of acceleration of gravity (g) (Dames and Moore 1973) to $0.19 \mathrm{~g}$ (TERA Corp. 1981). The discrepancy between these estimates results from uncertainties in the boundary of seismic source regions, earthquake recurrence relationships, and the magnitude of the maximum earthquake in each seismic source region, as well as from differing calculation methodologies (Saylor et al. 1990). The Department of Energy endor ces the result of the TERA Corp. seismic hazard analyses for setting seismic design guidelines (Kennedy et al. 1990) -- a 1,C J0-yr return period mean value for PGA of $19 \mathrm{~g}$. A detailed discussion of seismicity at the K-25 facility has been published (Saylor et al. 1990).

\subsection{Air Resources}

\subsubsection{Climate and Local Meteorology}

Oak Ridge is located in a broad valley between the Cumberland Mountains, which lie to the northwest of the area, and the Great Smoky Mountains, which lie to the southeast. These mountain ranges are oriented northeast-southwest; the valley between is corrugated by broken ridges 91 to 152 meters $(\mathrm{m})$ ( 300 to $500 \mathrm{ft}$ ) high and is oriented parallel to the main valley. The Great Smoky Mountains frequently divert the hot, southeasterly winds that often develop along the southern Atlantic coast. The area has a temperate climate, with warm, humid summers and cool winters. No extreme conditions prevail in temperature, precipitation, or winds. Spring and fall are usually long, and the weather in these seasons is normally sunny with mild temperatures. Temperatures of $38^{\circ} \mathrm{C}\left(100^{\circ} \mathrm{F}\right)$ or more have occurred during fewer than one-half of the years of the recorded period, and temperatures of $-18^{\circ} \mathrm{C}\left(0^{\circ} \mathrm{F}\right)$ or below are rare. Winter storms are generally of low intensity and long duration. Severe storms such as tornadoes or high-velocity winds are rare. Most of the data presented in this section were obtained from Kornegay et al. (1990).

The 39-year annual average precipitation (water equivalent) is $1.36 \mathrm{~m}$ (53.5 in.), including approximately $0.25 \mathrm{~m}$ (9.8 in.) of snowfall, with monthly precipitation peaking in January and February. Another peak in rainfall occurs in July, when short, heavy rains associated with thunderstorms are common. Typically in October, slow-moving high-pressure cells suppress rain and, while remaining nearly stationary for many days, provide mild, clear, dry weather. Poor air dilution (causing frequent air-pollution episodes) occurs with the greatest frequency and severity during October. 
The Oak Ridge area has average wind speeds. Local terrain exerts a dominating influence on daily wind patterns, contributing to the low wind speeds. Prevailing winds travel in two directions: up-valley (from the southwest) and down-valley (from the northeast). The atmosphere can be considered to be in an inversion status about $36 \%$ of the time. The daily up- and downvalley winds, however, provide some diurnal exchange. A wind rose analysis of the 10-m and 60$\mathrm{m}$ level wind-speed and wind-direction data collected during 1989 is presented in Fig. 9 for the K25 site's " $K$ " tower. As the 60-m measurement level of the figure shows, the predominant winds are from the southwest and northeast directions.

Data collected at the $10-\mathrm{m}$ and $60-\mathrm{m}$ levels at the $\mathrm{K}$ tower are used to determine the vertical structure of the atmosphere and possible vertical variations on releases from facilities. At each level, wind speed and wind direction are recorded, while atmospheric stability (a measure of the dispersive capability of the atmosphere) is determined from the wind direction fluctuation data obtained at the 60-m level. Winds measured at the $\mathrm{K}$ tower (as with all other towers on the ORR) are dominated by low-wind-speed conditions. The atmosphere over the Reservation is dominated by stable conditions on most nights and in the early morning hours. These conditions, coupled with the low wind speeds and channeling effects of the valleys, result in reduced dilution of material emitted from the facilities.

\subsubsection{Air Quality}

\subsubsection{Air Emissions}

Most of the air-pollution sources at K-25 are inactive as a consequence of the shutdown of the gas centrifuge development grogram and the ORGDP. Currently, only three large emission sources are operating. These are:

1. The $K-1501$ steam plant. To reduce opacity excursions, natural gas has been used as much as possible since 1985 . Because sufficient natural gas is not available under very cold winter conditions, No. 2 diesel fuel is burned during peak periods. The steam plant is in continuous operation, and this system has a continuous opacity monitor.

2. The K-1435 Toxic Substances Control Act (TSCA) incinerator. Emissions include small amounts of polychlorinated biphenyls (PCBs), dioxins, furans, uranium, and hexachlorobenzene. The incinerator was built to thermally destroy PCBs and other organic hazardous wastes.

3. The $K-1420$ decontamination facility. Uranium is emitted. Tests on compressors in building K-1401 can lead to additional uranium emissions. 

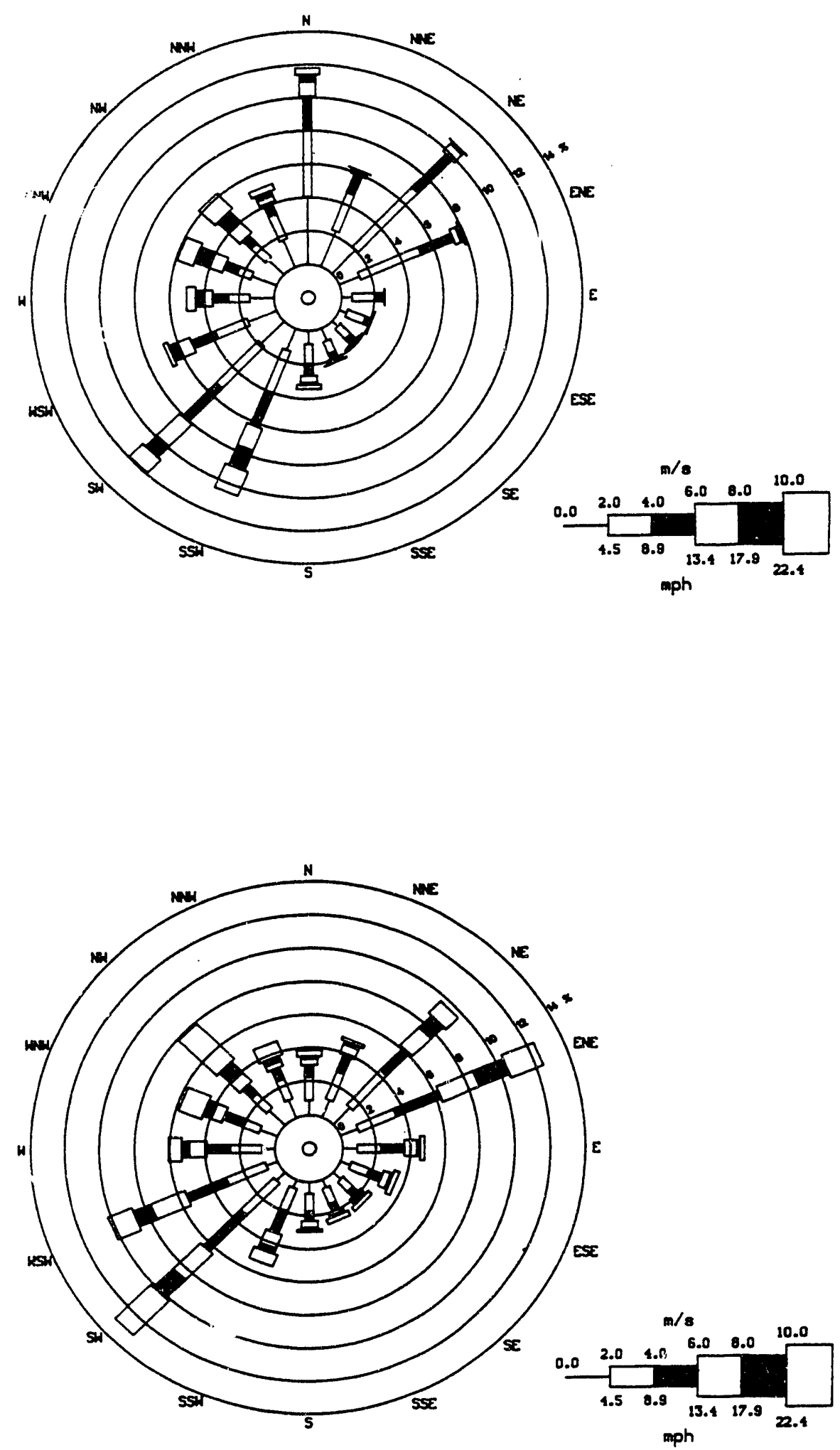

FIGURE 9 Wind Roses for 10-m (top) and 60-m (bottom) Levels of the Meteorological "K" Tower ar K-25 -- 1989 
Table 2, an emissions inventory for the year 1989, presents toxic chemical emissions, steam plant emissions, and radionuclide emissions. The locations of major emission sources are shown in Fig. 10. The K-1435 TSCA incinerator began operation in 1991, so its only emissions are from preliminary tests in 1989; 1990 and 1991 emission estimates for the source are not available at this time. Estimates of the pollutants emitted from the TSCA incinerator are based on continuous sampling and knowledge of actual operating times. As of 1990, the Tennessee Department of Health and Environment (TDHE) air compliance tests for lead, beryllium, and nitrogen oxide emissions still had to be completed before operation of the incinerator could begin. The only radioactive isotopes incinerated in the K-1435 TSCA incinerator during 1989 were uranium and technetium; therefore, no emissions of ${ }^{125} \mathrm{I}$ or ${ }^{131} \mathrm{I}$ are included, although emissions of such isotopes may be possible in the future. The emissions of uranium and technetium are well within the acceptable permit guidelines of 15,000 microcuries per year $(\mu \mathrm{Ci} / \mathrm{yr})$ for uranium and $394,000 \mu \mathrm{Ci} / \mathrm{yr}$ for technetium. In addition, carbon monoxide, carbon dioxide, and oxygen are continuously monitored to ensure that destructive efficiency for the incinerator is sufficient to destroy $99.9999 \%$ of all organic materials.

Uranium emissions from the K-25 site for 1989 resulted almost entirely from the testing operations at the K-1435 TSCA incinerator. Small amounts of ${ }^{99} \mathrm{Tc}$ in emissions from K-1420 and K-1435 were detected in samples collected in 1989.

There are currently no permitting requirements to sample or monitor all chemical emissions from K-25. Hotvever, estimates of the major gaseous chemicals emitted to the atmosphere in 1989, including those that require reporting under Title III of SARA, Section 313 (community "right-to-know" law), are presented in Table 2. Emissions for a chemical that was either not manufactured or processed in excess of 12.5 tons, or not otherwise used in excess of 5 tons (during 1989), did not need to be reported and therefore do not appear in the table. Work is underway at the ORNL to provide a more refined emissions inventory that includes such emissions. Fluoride emissions are zero and therefore are not included in the table since there were no emission sources in 1988 and 1989. Also, background monitoring for fluorides was suspended during 1989 for lack of emission sources.

\subsubsection{Ambient Air Quality}

The regulatory background of the ambient monitoring program is as follows. The K-25 area is subject to regulations issued by the TDHE Air Pollution Control Board, the U.S. Environmental Protection Agency (EPA), and DOE Orders. The TDHE and the EPA regulate nonradioactive emissions sources. Radioactive emission sources are regulated by the EPA under the National Emissions Standards for Hazardous Air Pollutants (NESHAP).

The TDHE and EPA air pollution control rules regulate pollution sources to protect the public health and welfare and the environment. These rules include regulations for maximum allowable ambient air concentrations of certain pollutants, open burning, pollution sources, fugitive emission sources, performance standards for new sources, and hazardous air pollutants. Stateissued permits are required for air pollution sources. 
TABLE 2 Air Pollutant Emissions Inventory for K-25, 1989 (pounds [lb] and kilograms [kg] unless otherwise indicated)

\begin{tabular}{|c|c|c|c|c|}
\hline $\begin{array}{l}\text { Chemical } \\
\text { Name }\end{array}$ & $\begin{array}{l}\text { Type of } \\
\text { Release }\end{array}$ & $\begin{array}{l}\text { Quantity } \\
\text { Released }\end{array}$ & $\begin{array}{c}\text { Major } \\
\text { Release Sources }\end{array}$ & $\begin{array}{l}\text { Basis of } \\
\text { Estime'e }\end{array}$ \\
\hline \multicolumn{5}{|c|}{ SARA 313 INVENTORY CHEMICALS ${ }^{a}$} \\
\hline Chlorine & Fugitive emissions & $34,000(15,000)$ & Neutralization & Material balance \\
\hline Sulfuric acid & Fugitive emissions & $<1(<1)$ & $\begin{array}{l}\text { Neutralization/ } \\
\text { storage }\end{array}$ & Otherb \\
\hline Methanol & Stack & $<1(<1)$ & $\begin{array}{l}\mathrm{K}-1435 \text { TSCA } \\
\text { incinerator tests }\end{array}$ & Monitoring \\
\hline $\begin{array}{l}\text { 1,1,1- } \\
\text { Trichloroethane }\end{array}$ & Stack & $14,000(6,200)$ & Degreasing & Material balance \\
\hline $\begin{array}{l}\text { Carbon } \\
\text { tetrachloride }\end{array}$ & Stack & $<1(<1)$ & $\begin{array}{l}\mathrm{K}-1435 \mathrm{TSCA} \\
\text { incinerator tests }\end{array}$ & Monitoring \\
\hline \multirow[t]{2}{*}{ Hydrochloric acid } & Stack emissions & $250(110)$ & $\begin{array}{l}\text { Cleaning/pickling/ } \\
\text { neutralization }\end{array}$ & Other ${ }^{b}$ \\
\hline & Fugitive emissions & $<1(<1)$ & Neutralization & Otherb \\
\hline \multicolumn{5}{|c|}{ OTHER LARGE INVENTORY CHEMICALS } \\
\hline Freon 11 & Fugitive emissions & $12,000(5,400)$ & $\begin{array}{l}\text { Refrigeration/ } \\
\text { cooling systems }\end{array}$ & Otherb \\
\hline Freon 22 & Fugitive emissions & $2,200(1,000)$ & $\begin{array}{l}\text { Refrigeration/ } \\
\text { cooling systems }\end{array}$ & Other \\
\hline \multicolumn{5}{|c|}{ STEAM PLANT EMISSIONS } \\
\hline Particulates & Stack emissions & $13,000(5,800)$ & $\begin{array}{l}\text { Fossil fuels } \\
\text { combustion }\end{array}$ & $\begin{array}{l}\text { Emission } \\
\text { factors }\end{array}$ \\
\hline Sulfur dioxide & Stack emissions & $28,000(13,000)$ & $\begin{array}{l}\text { Fossil fuels } \\
\text { combustion }\end{array}$ & $\begin{array}{l}\text { Emission } \\
\text { factors }\end{array}$ \\
\hline Nitrogen oxides & Stack emissions & $7 ?, 000(32,000)$ & $\begin{array}{l}\text { Fossil fuels } \\
\text { combustion }\end{array}$ & $\begin{array}{l}\text { Emission } \\
\text { factors }\end{array}$ \\
\hline Carbon monoxide & Air stack emissions & $12,000(5,600)$ & $\begin{array}{l}\text { Fossil fuels } \\
\text { combustion }\end{array}$ & $\begin{array}{l}\text { Emission } \\
\text { factors }\end{array}$ \\
\hline \multicolumn{5}{|c|}{ RADIONUCLIDE EMISSIONS (grams [g] and kg or $\mu \mathrm{Ci}$ ) } \\
\hline Technetium ( $\left.{ }^{99} \mathrm{Tc}\right)$ & Stack emissions & $\begin{array}{c}0.32 \mathrm{~g} \\
(0.0054 \mu \mathrm{Ci})\end{array}$ & See Fig. 10 & Not available \\
\hline Uranium & Stack emissions & $\begin{array}{c}1.11 \mathrm{~kg} \\
(0.0004 \mu \mathrm{Ci})\end{array}$ & See Fig. 10 & Not available \\
\hline
\end{tabular}

\footnotetext{
These chemicals are summarized from information compiled as required by the Superfund Amendments and Reauthorization Act (SARA) Title III, Sec. 313. This report contains chemicals on the Environmental Protection Agency (EPA) toxic substance list.

bBased on best engineering judgment.

CEPA Document AP-42, "Compilation of Air Pollutant Emission Factors."
} 


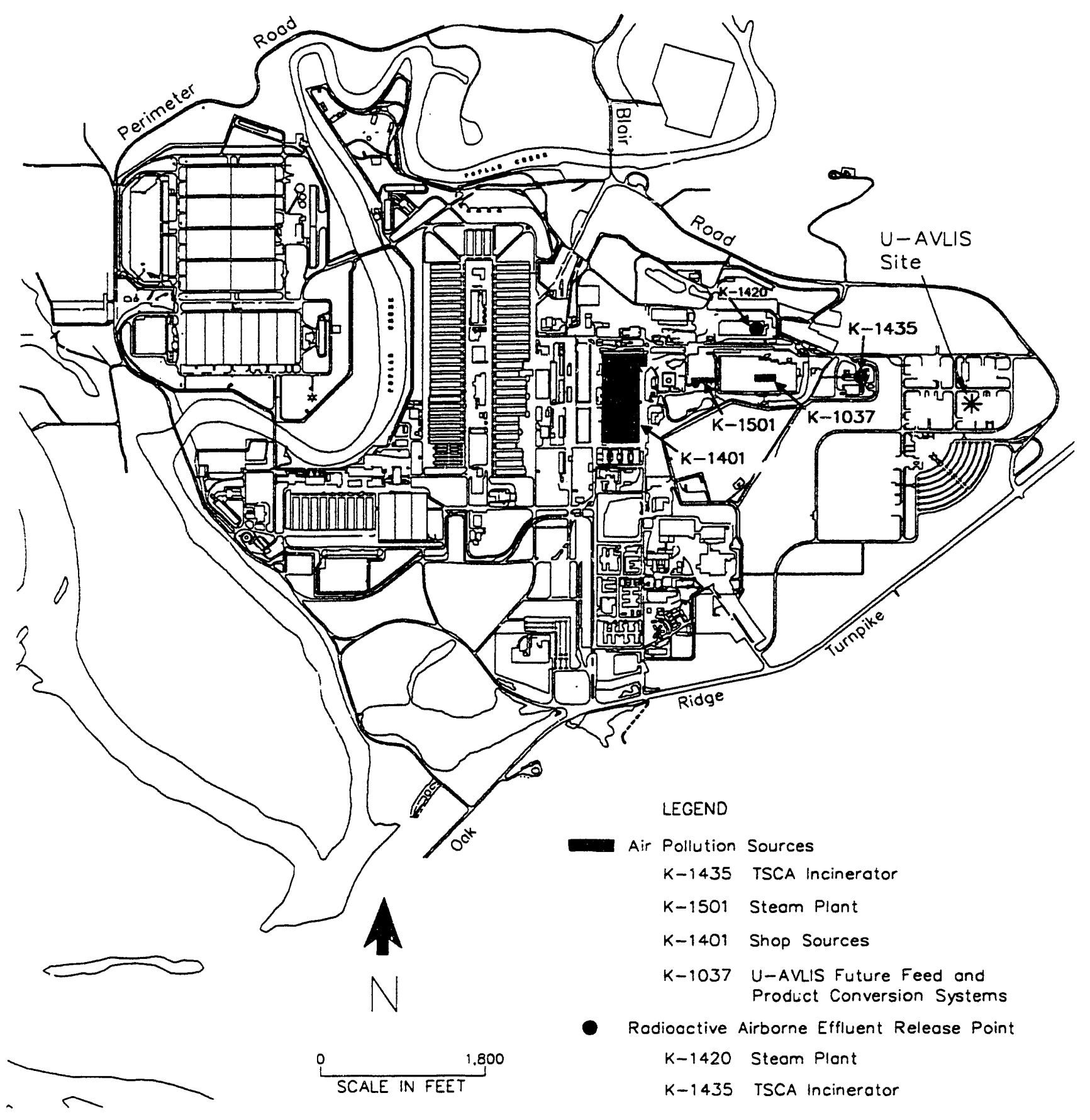

FIGURE 10 Locations of the Largest Air Pollution Sources at K-25 
The EPA rules for radioactive emission sources limit the amount of exposure to radioactivity to the nearest or the most affected member of the public. The EPA sets the limit on exposure to radioactivity by first determining a safe exposure level and then adding a margin of safety. The most affected member of the public is determined by EPA-approved radioactive emissions dose modeling. The NESHAP rules were reissued in December 1989, and efforts are underway at K-25 to implement these new requirements.

The locations of 10 ambient monitoring stations in the near vicinity of the K-25 site are shown in Fig. 11. These stations are arranged in three functional groups, as follows.

1. Five stations that measure concentrations of total suspended particulates (TSP), including particulates measuring less than 10 microns in diameter $\left(\mathrm{PM}_{10}\right)$; and of lead, chromium, nickel, and uranium. These stations are positioned for the predominant wind directions. These monitors sample ambient air for 24 hours (h) every sixth day to be consistent with the TDHE-established TSP sampling schedule. (A separate $\mathrm{PM}_{10}$ particulate monitor at the $\mathrm{K}-5$ station is also operating.) Table 3 presents the 1989 results for the K1-K5 stations (including those of the $\mathrm{PM}_{10}$ monitor).

2. Two TSCA monitoring stations (1 and 2), which measure PCBs, dioxins, furans, and hexachlorobenzene. Table 4 presents the background levels of pollutants measured by TSCA1 and TSCA2. These sampling stations were installed in 1988 and were designed to detect specific chemicals that may be emitted from possible upsets of the K-1435 TSCA incinerator. The results shown in Table 4 were derived from several background tests conducted with the TSCA ambient air monitors while the TSCA incinerator was not operational. There are no standards for ambient levels of PCBs, dioxins, furans, and hexachlorobenzene. Work is underway at ORNL to compare the K-25 background data with national ambient levels and to develop internal guidelines for standards that should exist for these pollutants. A preliminary review indicates that the ambient levels of these pollutants detected near the ORGDP are similar to those found in other rural and industrial areas of the United States. The TSCA 1 and 2 ambient air monitors are operational 24 hours per day, 7 days per week, as long as the TSCA incinerator is operational (when waste is being burned).

3. Three perimeter air monitoring (PAM) stations -- see locations 33,42 , and 43 in Fig. 11 -- that measure gross alpha and gross beta radioactivity continuously, with a biweekly collection/ralysis frequency. All data are within ambient standards, including the gross alpha and gross beta radioactivity data froin PAM stations 33,42 , and 43 (data not shown). 


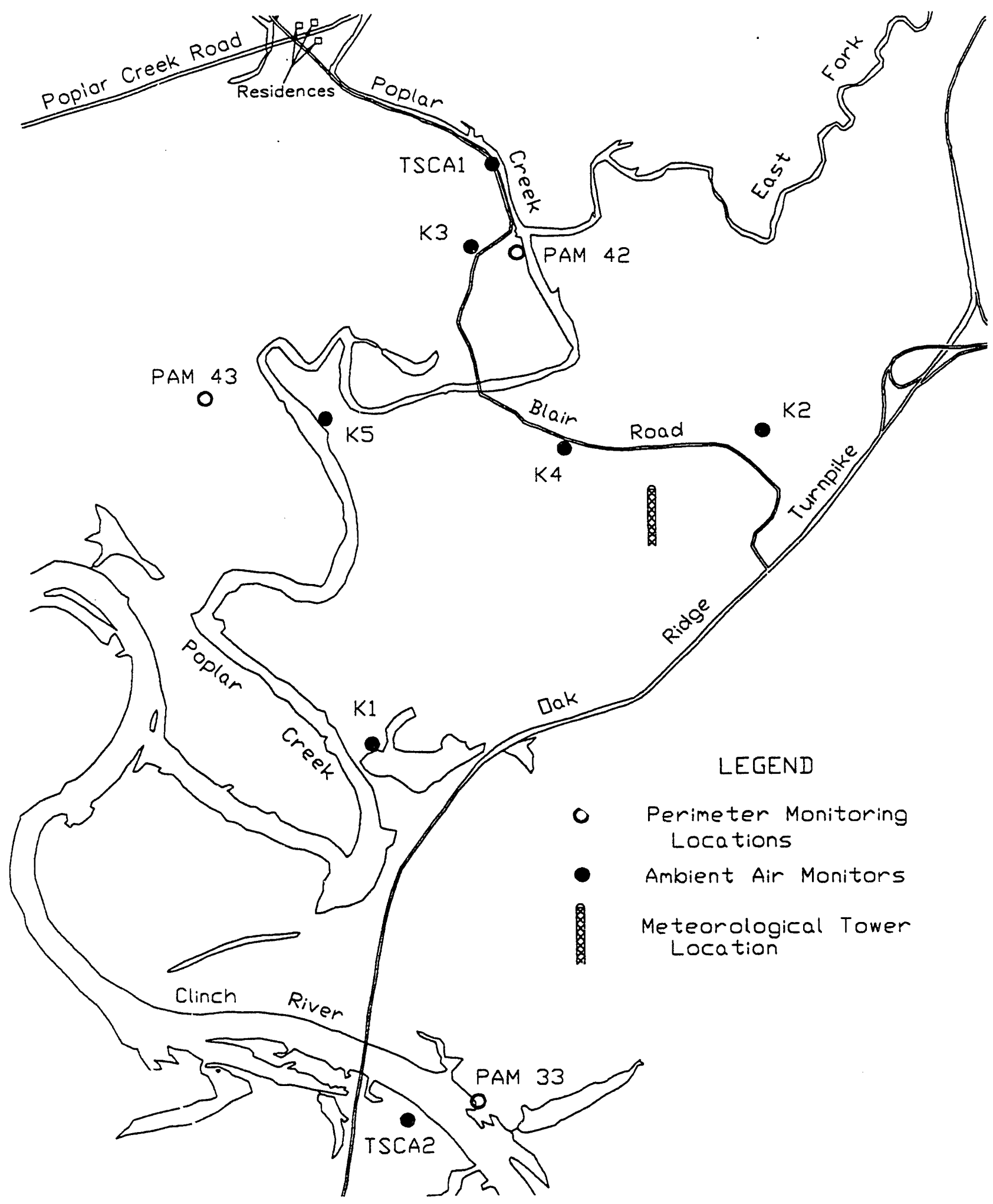

FIGURE 11 Locations c 10 Ambient Air Monitoring Stations Operated by the ORR in the Vicinity of K-25 
TABLE 3 Ambient Monitoring Data for 1989 from the K1-K5 Air Monitors

\begin{tabular}{|c|c|c|c|c|c|c|}
\hline \multirow{3}{*}{$\begin{array}{l}\text { Pollutants } \\
\text { Sampled, } \\
\text { by Sampling } \\
\text { Pointa }^{\mathrm{a}}\end{array}$} & \multirow{3}{*}{$\begin{array}{c}\text { No. of } \\
\text { Samples }\end{array}$} & \multirow{2}{*}{\multicolumn{3}{|c|}{ 24-h Concentration $\left(\mu \mathrm{g} / \mathrm{m}^{3}\right)^{\mathrm{b}}$}} & \multicolumn{2}{|c|}{ Percentage of Standard } \\
\hline & & & & & \multirow{2}{*}{$\begin{array}{l}\text { Primary } \\
\text { Standard }\end{array}$} & \multirow{2}{*}{$\begin{array}{l}\text { Secondary } \\
\text { Standard }\end{array}$} \\
\hline & & Max & Min & Avg & & \\
\hline \multicolumn{7}{|l|}{ TSPC } \\
\hline K1 & 59 & 47.0 & 0.0 & 3.17 & 18 & 31 \\
\hline $\mathrm{K} 2$ & 59 & 42.5 & 0.0 & 3.99 & 5 & 6 \\
\hline K3 & 60 & 47.0 & 0.0 & 4.93 & 6 & 8 \\
\hline K4 & 60 & 46.4 & 0.0 & 8.99 & 11 & 14 \\
\hline K5 & 59 & 42.4 & 0.0 & 7.37 & 9 & 12 \\
\hline$P M_{10}^{d}$ & 60 & 46.5 & 0.0 & 7.34 & 31 & 31 \\
\hline \multicolumn{7}{|l|}{ Leade } \\
\hline $\mathrm{K} 1$ & 61 & 0.026 & $<0.0048$ & $<0.0093$ & 2 & $N / A^{f}$ \\
\hline $\mathrm{K} 2$ & 60 & 0.018 & 0.0047 & 0.0087 & 1 & $N / A^{\dagger}$ \\
\hline K3 & 61 & 0.018 & 0.0047 & 0.0090 & 1 & $N / A^{f}$ \\
\hline $\mathrm{K} 4$ & 61 & 0.019 & 0.0040 & 0.0093 & 1 & $N / A^{\dagger}$ \\
\hline $\mathrm{K} 5$ & 60 & 0.057 & $<0.0043$ & $<0.0089$ & 4 & $N / A^{f}$ \\
\hline \multicolumn{7}{|l|}{ Chromiumg } \\
\hline $\mathrm{K} 1$ & 61 & $<0.003$ & $<0.0023$ & $<0.0025$ & $N / A^{\dagger}$ & $N / A^{\dagger}$ \\
\hline $\mathrm{K} 2$ & 60 & $<0.003$ & $<0.0023$ & $<0.0025$ & $N / A^{f}$ & $N / A^{f}$ \\
\hline $\mathrm{K} 3$ & 61 & 0.004 & $<0.0023$ & $<0.0025$ & $N / A^{f}$ & $N / A^{f}$ \\
\hline K4 & 61 & $<0.003$ & $<0.0018$ & $<0.0024$ & $N / A^{f}$ & $N / A^{\dagger}$ \\
\hline K5 & 60 & $<0.003$ & $<0.0021$ & $<0.0023$ & $N / A^{f}$ & $N / A^{f}$ \\
\hline \multicolumn{7}{|l|}{ Nickelg } \\
\hline $\mathrm{K} 1$ & 61 & 0.013 & $<0.0023$ & $<0.0034$ & $N / A^{f}$ & $N / A^{f}$ \\
\hline $\mathrm{K} 2$ & 60 & 0.014 & $<0.0023$ & $<0.0032$ & $N / A^{f}$ & $N / A^{f}$ \\
\hline K3 & 61 & 0.010 & $<0.0023$ & $<0.0031$ & $N / A^{f}$ & $N / A^{f}$ \\
\hline K4 & 61 & 0.013 & $<0.0120$ & $<0.0033$ & $N / A^{f}$ & $N / A^{f}$ \\
\hline K5 & 60 & 0.009 & $<0.0021$ & $<0.0029$ & $N / A^{f}$ & $N / A^{f}$ \\
\hline \multicolumn{7}{|l|}{ Uranium $^{h}$} \\
\hline $\mathrm{K} 1$ & 61 & 0.001 & $<0.0001$ & $<0.0001$ & 1 & $N / A^{f}$ \\
\hline $\mathrm{K} 2$ & 60 & 0.001 & $<0.0001$ & $<0.0001$ & 1 & $N / A^{f}$ \\
\hline K3 & 61 & 0.001 & $<0.0001$ & $<0.0001$ & 1 & $N / A^{f}$ \\
\hline $\mathrm{K} 4$ & 61 & 0.001 & $<0.0001$ & $<0.0001$ & 1 & $N / A^{f}$ \\
\hline K5 & 60 & 0.002 & $<0.0001$ & $<0.0001$ & 1 & $N / A^{f}$ \\
\hline
\end{tabular}


TABLE 3 Footnotes (Cont'd)

aLocations shown in Fig. 11.

bMicrograms per cubic meter.

CPrimary standard for TSP for the state of Tennessee is $260 \mu \mathrm{g} / \mathrm{m}^{3}$ per $24 \mathrm{~h}$. Secondary standard for TSP for the state of Tennessee is $150 \mu \mathrm{g} / \mathrm{m}^{3}$ per $24 \mathrm{~h}$. $\mathrm{PM}_{10}$ is $150 \mu \mathrm{g} / \mathrm{m}^{3}$ per $24 \mathrm{~h}$ for primary and secondary standards.

${ }^{d} P_{10}$ is monitored as part of the $K 5$ sampling point for TSP.

eThe primary standard for lead is $1.5 \mu \mathrm{g} / \mathrm{m}^{3}$.

fNot applicable.

gNo ambient air standards.

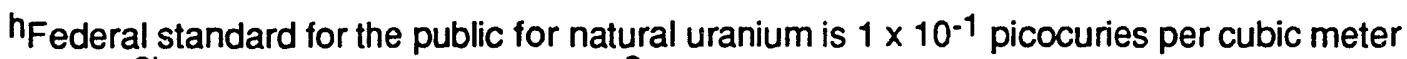
(pCi/m $\mathrm{m}^{3}$, which converts to $0.15 \mu \mathrm{g} / \mathrm{m}^{3}$. There are no TDHE ambient standards for uranium.

TABLE 4 Ambient Monitoring Data (24-h average) for 1989 from the TSCA1 and TSCA2 Air Monitors

\begin{tabular}{|c|c|c|c|c|}
\hline \multirow{2}{*}{$\begin{array}{l}\text { Chemicals } \\
\text { Sampled } \\
\text { (in nanograms or } \\
\text { picograms per } \\
\text { cubic meter), by } \\
\text { Sampling Point }\end{array}$} & \multirow{2}{*}{$\begin{array}{l}\text { No. of } \\
\text { Samples }\end{array}$} & \multicolumn{3}{|c|}{ Concentration } \\
\hline & & Maximum & Minimum & Average \\
\hline $\begin{array}{l}\text { PCBs }\left(n g / m^{3}\right)^{b} \\
\text { TSCA1 } \\
\text { TSCA2 }\end{array}$ & $\begin{array}{l}5 \\
5\end{array}$ & $\begin{array}{l}0.47 \\
1.02\end{array}$ & $\begin{array}{l}0.10 \\
0.18\end{array}$ & $\begin{array}{l}0.23 \\
0.48\end{array}$ \\
\hline $\begin{array}{l}\text { Dioxins }\left(\mathrm{pg} / \mathrm{m}^{3}\right)^{b} \\
\text { TSCA1 } \\
\text { TSCA2 }\end{array}$ & $\begin{array}{l}6 \\
6\end{array}$ & $\begin{array}{l}1.534 \\
1.004\end{array}$ & $\begin{array}{l}0.121 \\
0.096\end{array}$ & $\begin{array}{l}0.789 \\
0.573\end{array}$ \\
\hline $\begin{array}{l}\text { Furans }\left(\mathrm{pg} / \mathrm{m}^{3}\right)^{\mathrm{b}} \\
\text { TSCA1 } \\
\text { SCA2 }\end{array}$ & $\begin{array}{l}6 \\
6\end{array}$ & $\begin{array}{l}0.707 \\
1.424\end{array}$ & $\begin{array}{l}0.281 \\
0.266\end{array}$ & $\begin{array}{l}0.429 \\
0.656\end{array}$ \\
\hline $\begin{array}{l}\text { Hexachlorobenzen } \\
\text { TSCA1 } \\
\text { TSCA2 }\end{array}$ & $\begin{array}{l}\left(\mathrm{ng} / \mathrm{m}^{3}\right)^{\mathrm{k}} \\
6 \\
5\end{array}$ & $\begin{array}{l}0.035 \\
0.031\end{array}$ & $\begin{array}{l}0.006 \\
0.007\end{array}$ & $\begin{array}{l}0.020 \\
0.016\end{array}$ \\
\hline
\end{tabular}

aLocations shown in Fig. 11.

bNo ambient standards have been set for these pollutants. 
In addition to the 10 monitoring stations operated for environmental compliance for $\mathrm{K}-25$, there are external monitoring stations operated by the state of Tennessee. The locations of these stations are shown in Fig. 12. The stations provide data on the sriteria pollutants that allow estimates of background values for the K-25 site. Table 5 provides estimates from the most relevant stations to the K-25 site and a comparison with ambient air standards. The most relevant stations were chosen in terms of distance from the site and types of sources in the area. It may be concluded that all monitoring data were found to be within applicable standards for the K-25 site, whether measured by ORNL or the state of Tennessee.

\subsection{Noise}

The nearest residences to the proposed K-25 location of the U-AVLIS plant are along Poplar Creek Road (off Blair Road) to the northeast of the site (see Fig. 11). During a field measurement survey taken by ANL staff in the preparation of this document on June 18, 1991, at 8:30 a.m., it was not possible to distinguish the noise from K-25 activities at the location of the three residences on Blair Road nearest the site. Measured ambient noise levels at this location were as follows:

$\begin{array}{llllllllllc}31 & 63 & 125 & 250 & 500 & 1 & 2 & 4 & 8 & 16 & \begin{array}{c}\text { A-weighted } \\ \underline{\mathrm{Hz}}\end{array} \\ \underline{\mathrm{Hz}} & \underline{\mathrm{Hz}} & \underline{\mathrm{Hz}} & \underline{\mathrm{Hz}} & \underline{\mathrm{kHz}} & \underline{\mathrm{kHz}} & \underline{\mathrm{kHz}} & \underline{\mathrm{kHz}} & \underline{\mathrm{kHz}} & \underline{\text { decibels (dBA) }} \\ 65 & 47 & 46 & 41 & 27 & 26 & 27 & 32 & 29 & 29 & 38.7\end{array}$

These measurements represent 10 -second averages when cars could not be heard. Automobile traffic is the main source of noise at these residences during the day, but the measurements made were aimed at eliminating those transient passbys and obtaining residual background levels. Background noise levels presented above did include the noise of birds and background mass transportation noise far off in the distance. These noise levels are very low and representative of a rural environment.

\subsection{Water Resources}

\subsubsection{Regional Surface Water}

Figure 13 illustrates the major surface drainage in the vicinity of the K-25 site. All surface water in the region ultimately drains to the Tennessee River (Saylor et al. 1990). The southwestflowing Clinch River has its headwaters in southwest Virginia approximately 175 air mi northeast of the ORR. The Clinch River drainage basin constitutes an area of $4,413 \mathrm{mi}^{2}$ and represents about $11 \%$ of the Tennessee River watershed. Three dams operated by the TVA affect flow in the Clinch River (Rothschild et al. 1984). Two of these, the Melton Hill and Norris dams, are located upstream of K-25 on the Clinch River. Watts Bar Dam, on the Tennessee River downstream of K-25, principally affects the lower reaches of the Clinch River. Discharge in the Clinch River in 


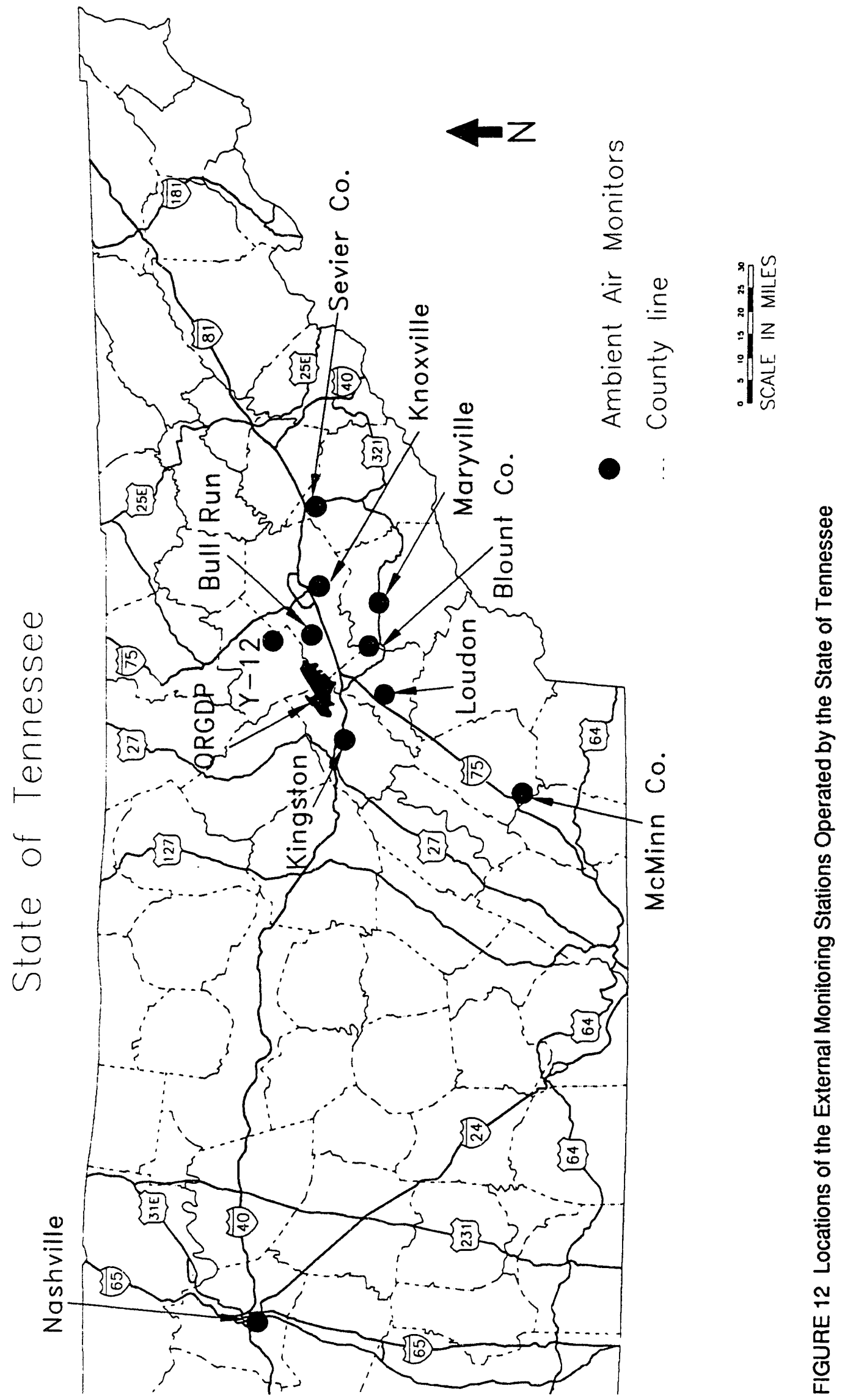


TABLE 5 Comparison of 1990 Ambient Air Monitoring Data from Selected Stations of the Tennessee Monitoring Network with Tennessee Regulations for the Criteria Pollutants $\left(\mu \mathrm{g} / \mathrm{m}^{3}\right)$

\begin{tabular}{|c|c|c|c|c|c|c|c|}
\hline \multirow[b]{2}{*}{ Pollutant } & \multirow{2}{*}{$\begin{array}{l}\text { Monitoring } \\
\text { Locationa }\end{array}$} & \multirow{2}{*}{$\begin{array}{l}\text { Averaging } \\
\text { Period }\end{array}$} & \multicolumn{2}{|c|}{$\begin{array}{c}\text { Prevention of } \\
\text { Significant Deterioration } \\
\text { Increment } \\
\end{array}$} & \multicolumn{2}{|c|}{$\begin{array}{c}\text { National Ambient } \\
\text { Air Quality } \\
\text { Standard } \\
\end{array}$} & \multirow{2}{*}{$\begin{array}{c}\text { Estimated } \\
1990 \\
\text { Ambient } \\
\text { Level at } \\
\text { K-25 Site }\end{array}$} \\
\hline & & & Primary & Secondary & Class I & Class II & \\
\hline $\begin{array}{l}\text { Sulfur } \\
\text { dioxide }\end{array}$ & $\begin{array}{l}\text { Kingston } \\
\text { Y-12 East } \\
\text { Bull Run }\end{array}$ & $\begin{array}{l}\text { Annual } \\
\text { 24-hourb } \\
\text { 3-hourb } \\
\text { Annual } \\
\text { 24-hourb } \\
\text { 3-hourb } \\
\text { Annual } \\
\text { 24-hourb } \\
\text { 3-hourb }\end{array}$ & $\begin{array}{r}80 \\
365 \\
\\
80 \\
305\end{array}$ & $\begin{array}{r}- \\
1300 \\
1300\end{array}$ & $\begin{array}{c}2 \\
5 \\
2 j\end{array}$ & $\begin{array}{r}20 \\
91 \\
512\end{array}$ & $\begin{array}{r}75 \\
267 \\
6 \\
61 \\
192 \\
6 \\
61 \\
292\end{array}$ \\
\hline $\begin{array}{l}\text { Nitrogen } \\
\text { dioxide }\end{array}$ & McMinn Co. & Annual & 100 & 100 & 2.5 & 25 & - \\
\hline $\begin{array}{l}\text { Carbon } \\
\text { monoxide }\end{array}$ & Knoxville & $\begin{array}{l}\text { 8-hourb } \\
1 \text {-hourb }\end{array}$ & $\begin{array}{l}10,000 \\
40,000\end{array}$ & - & - & - & $\begin{array}{r}5,900 \\
10,500\end{array}$ \\
\hline Ozone & $\begin{array}{l}\text { Blount Co. } \\
\text { Knoxville } \\
\text { Sevier Co. }\end{array}$ & $\begin{array}{l}1 \text {-hourc } \\
1 \text {-hourc } \\
1 \text {-hourc }\end{array}$ & 235 & 235 & - & - & $\begin{array}{l}210 \\
241^{d} \\
198\end{array}$ \\
\hline $\begin{array}{l}\text { Inhalable } \\
\text { particulates }\end{array}$ & $\begin{array}{l}\text { Maryville } \\
\text { Loudon } \\
\text { Knoxville }\end{array}$ & $\begin{array}{l}\text { Annual } \\
\text { 24-hourb } \\
\text { Annual } \\
\text { 24-hourb } \\
\text { Annual } \\
\text { 24-hourb }\end{array}$ & $\begin{array}{r}50 \\
150\end{array}$ & $\begin{array}{r}50 \\
150\end{array}$ & $\begin{array}{l}4^{f} \\
8^{f}\end{array}$ & $\begin{array}{l}17^{f} \\
30^{f}\end{array}$ & $\begin{array}{r}64 \\
52 \\
- \\
73\end{array}$ \\
\hline $\begin{array}{l}\text { Particulate } \\
\text { lead in TSP }\end{array}$ & Nashville & 3-month9 & 1.5 & 1.5 & - & - & 0.12 \\
\hline Fluorides ${ }^{h}$ & & $\begin{array}{l}\text { 30-dayb } \\
\text { 7-dayb } \\
\text { 24-hourb } \\
\text { 12-hourb }\end{array}$ & $\begin{array}{l}1.2^{i} \\
1.6^{i} \\
2.0^{i} \\
3.7^{i}\end{array}$ & & & & $\begin{array}{l}n / a^{j} \\
n / a^{j} \\
n / a j \\
n / a j\end{array}$ \\
\hline
\end{tabular}

aApproximate distances from the proposed U-AVLIS site: Kingston, $10 \mathrm{mi} \mathrm{W}$; Y-12, $7 \mathrm{mi} E$; Bull Run, $5 \mathrm{mi}$ E; McMinn Co., $40 \mathrm{mi} \mathrm{S}$; Knoxville, $25 \mathrm{mi} \mathrm{E;} \mathrm{Maryville} \mathrm{and} \mathrm{Blount} \mathrm{Co.,} 30 \mathrm{mi}$ SE;

Sevier Co., $42 \mathrm{mi}$ E; Loudon, $18 \mathrm{mi}$ S; Nashville, $130 \mathrm{mi} \mathrm{W}$.

b Not to be exceeded more than once per year. 
TABLE 5 Footnotes (Cont'd)

CNot to be exceeded on more than one day per year.

${ }^{d}$ Currently, the nearby counties of Knox, Anderson, Blount, and Jefferson are deemed "marginally nonattainment" for ozone by the EPA and the state of Tennessee. However, Roane Co., bcation of the K-25 site, is considered "attainment" for ozone by both entities. Anderson Co. borders Roane Co., and Knox Co. touches Roane $\mathrm{Co}$. at one point. Jefferson and Blount counties do not border or touch Roane Co.

oparticulate matter less than 10 microns in diameter.

'Proposed standard.

gCalendar quarter.

hGaseous fluorides expressed as hydrogen fluoride (HF). Measured beyond site boundary.

istate of Tennessee standards.

iNot applicable. No requirements were released, and therefore no measurements were made.

the vicinity of K-25 is directly affected by the Melton Hill Dam. Zero discharge within the Clinch River has occurred on many days since the dam gates were closed in 1963 (Saylor et al. 1990). An average discharge for the Clinch River in the K-25 vicinity during 1988 was 4,519 cubic feet per second (cfs). During peak hydroelectric demands, however, intermittent releases from the Melton Hill Dam may produce flows in the Clinch River as great as 18,000 cfs. Poplar Creek in the vicinity of K-25 drains approximately $136 \mathrm{mi}^{2}$ and has an average discharge of $162 \mathrm{cfs}$. East Fork Poplar Creek drains an area of $30 \mathrm{mi}^{2}$ and discharges approximately $49 \mathrm{cfs}$ to Poplar Creek. Average discharge data for Bear Creek are not available; however, maximum and minimum recorded discharges are $593 \mathrm{cfs}$ and $0.35 \mathrm{cfs}$, respectively (Rothschild et al. 1984). The elevation of the proposed U-AVLIS site is approximately $830 \mathrm{ft}$ MSL, well above the design basis flood level of 755 to $760 \mathrm{ft}$ (Martin Marietta 1990).

Clinch River and Poplar Creek contain moderately hard water and a total dissolved solids (TDS) content of less than 250 milligrams per liter $(\mathrm{mg} / \mathrm{L})$. Only nitrogen concentrations exceed the EPA's 1986 national drinking water standards in Clinch River and Poplar Creek (Saylor et al. 1990). Surface water quality in the vicinity of K-25 is affected by discharges from both ORR facilities and the city of Oak Ridge (Rothschild et al. 1984). In particular, East Fork Poplar Creek receives effluent from the industrial processes at the Y-12 site on ORR, as well as municipa! sewage discharges from the city of Oak Ridge. Chemical and thermal water quality of the Clinch River can also be affected by flow regulation at TVA dams. Approximately 3,109 cfs were withdrawn from the Clinch-Tennessee river system during 1982 (Rothschild et al. 1984). Users included private industry, the ORR, the TVA, and the city of Oak Ridge. The TVA was the largest user, withdrawing 3,049 cfs for use at the Bull Run and Kingston steam plants. During full-scale operation, the K-25 site withdrew $15 \mathrm{cfs}$ from the Clinch River for makeup cooling water (Saylor et al. 1990) and $4.6 \mathrm{cfs}$ for process and potable water (Rothschild et al. 1984). Current K-25 demand from surface water resources is $7 \mathrm{cfs}$. 


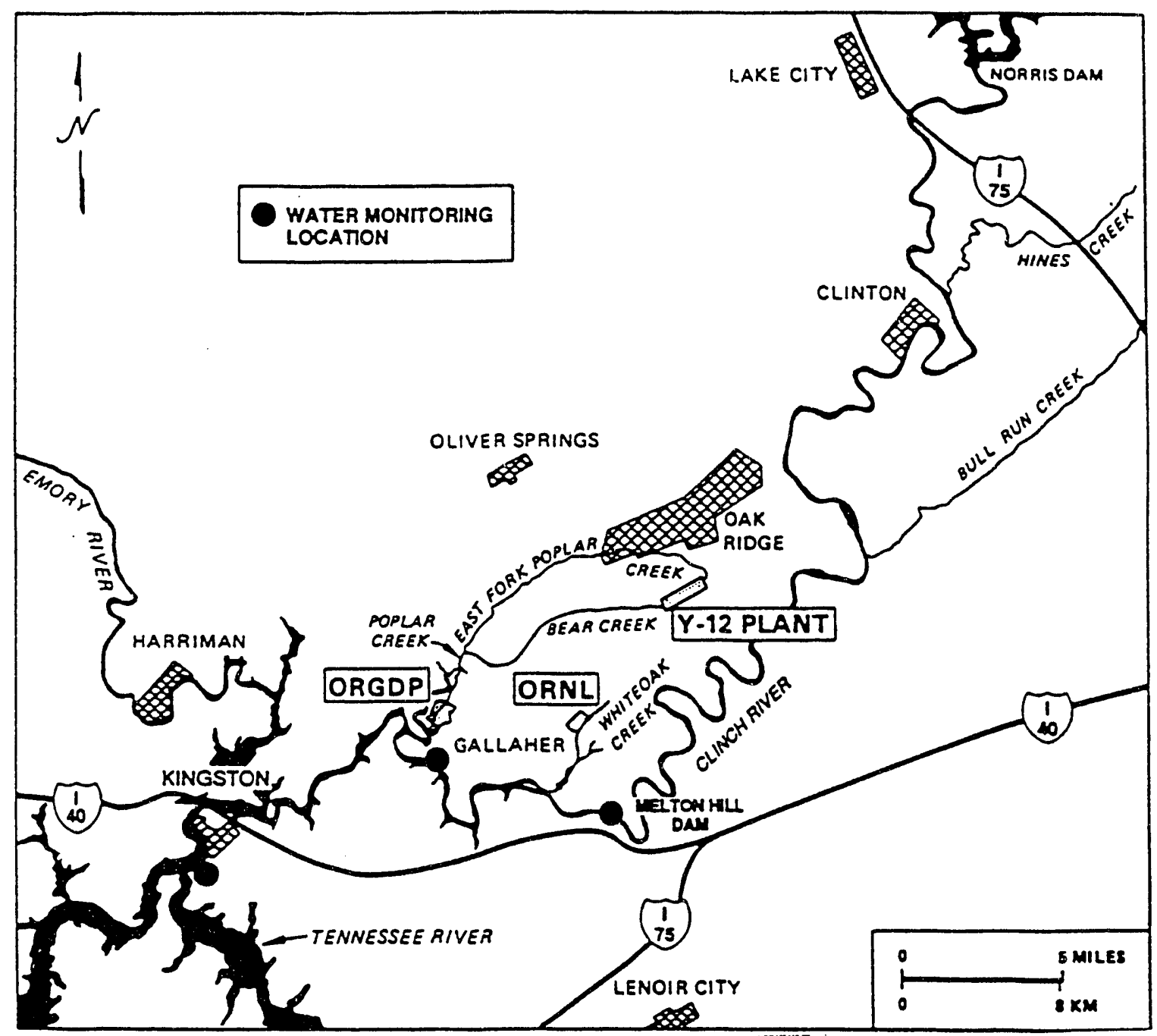

FIGURE 13 Major Surface Drainage in the Vicinity of K-25 (Source: Kornegay et al. 1990)

\subsubsection{Local Surface Water}

Figure 14 illustrates surface water features of the K-25 site. Poplar Creek runs southwest through the site to its confluence with the Clinch River. Mitchell Branch, an ephemeral stream, drains a small watershed in the northeastern part of $\mathrm{K}-25$. These streams receive $\mathrm{K}-25$ effluent that includes surface runoff, metal-cleaning and uranium-recovery wastewater, coal pile runoff, and other liquid wastes from site facilities. The liquid wastes are processed to isolate and remove the entrained contaminants prior to release at National Pollutant Discharge Elimination System (NPDES) outfalls. Holding ponds and lagoons also exist on K-25. Associated with the holding ponds and lagoons and other discharge points are eight NPDES monitoring locations. Monitoring for both radiological and nonradiological contaminants occurs at the NPDES outfalls. Radiological effluent is within required limits, and compliance is $97 \%$ for sampled nonradiological contaminants (Kornegay et al. 1990). The water quality of Mitchell Branch is influenced by K-25 site effluent, which can account for up to $31 \%$ of the stream's flow (Saylor et al. 1990). The contaminants 


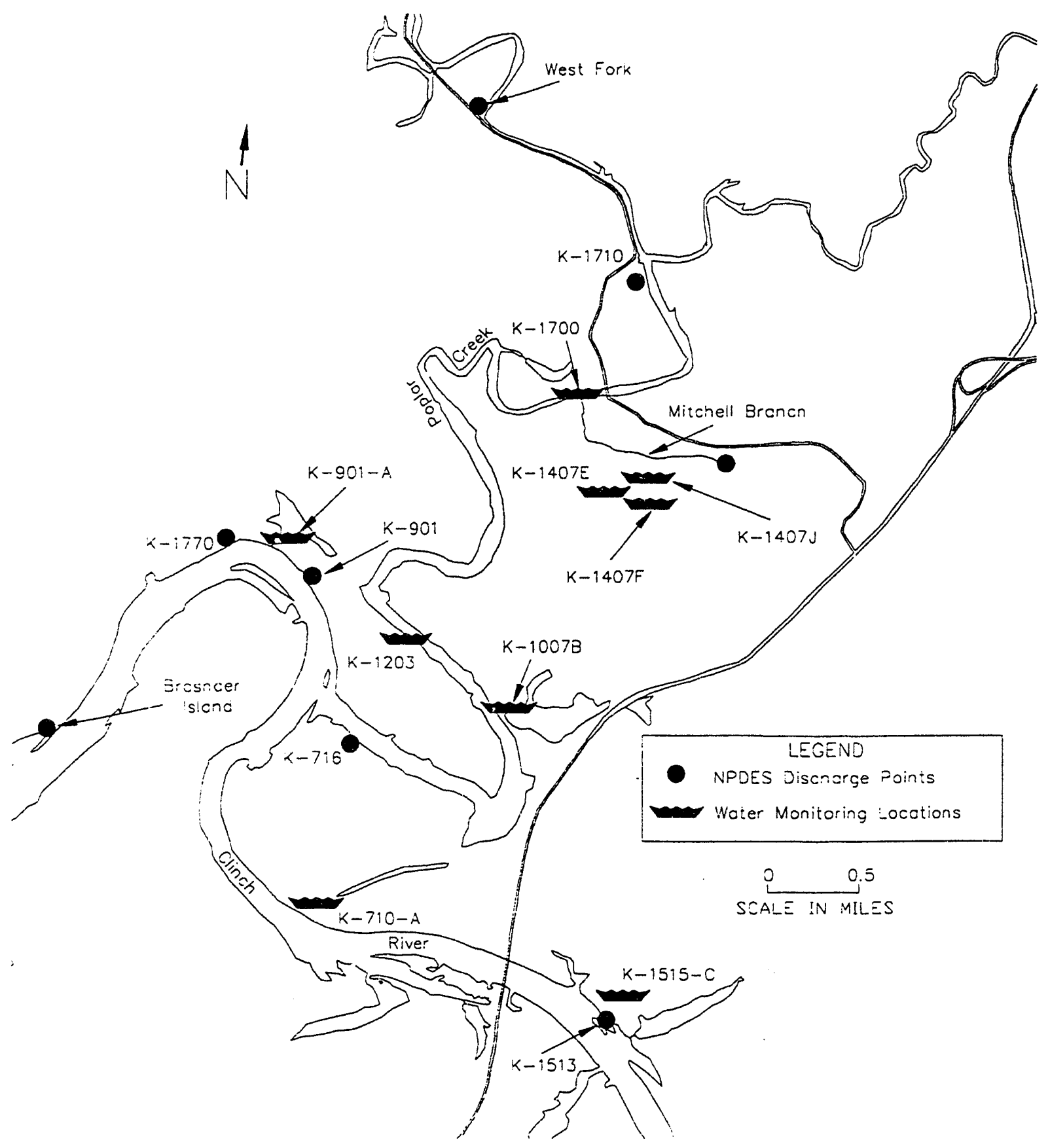

FIGURE 14 K-25 NPDES Discharge and Other Water-Monitoring Locations (Source: Kornegay et al. 1990) 
found in Mitchell Branch include chlorine, metals, and organics Clinch River sediments have bee 'sampled in the vicinity of the K-25 site. The results show sise presence of elevated sediment concentrations of chromium, copper, lead, mercury, nickel, and zinc. Detailed discussions of the surface water quality at the K-25 site have been published (Saylor et al. 1990; Kornegay et al. 1990).

\subsubsection{Regional Groundwater}

Little is known about the hydraulic relationships between lithologic units or about groundwater on a regional scale (Rothschild et al. 1984). Regionally, flow is strongly influenced by topography, and oroundwater discharge areas are the major river systems and their headwaters. Because the stream: do not fully penetrate surface aquifers, however, interbasinal flow probably occurs, but to an unknown extent.

\subsubsection{Local Grounowater}

Several aquifer zones have been identified at the K-25 site. Among these zones are a surficial aquifer and several bedrock aquifers. No groundwater users have been identified for the $\mathrm{K}-25$ site vicinity.

\subsubsection{Surficial Aquifer}

The surficial aquifer is made up of unconsolidated material that overlies the bedrock (Saylor et al. 1990). In general, the surficial deposits are up to $30 \mathrm{ft}$ thick and consist of weathered bedrock, alluvium, and fine-grained floodplain sediments except where disturbed by man-made fill. The weathered bedrock found ar K-25 has a high clay content and may also contain silt, sand, and rock fragments. Alluvium is found at K-25 along the Clinch River and in places along the banks of Poplar Creek. The allivium can contain sand, silt, and clay. Several permeability tests have been performed on the unconsolidated sediments found at K-25 (Geraghty and Miller 1989). The resuis $s$ of these tests indicate that permeabilities for the unconsolidated sediments range from $10^{-6}$ to $10^{-3}$ feet per minute $(\mathrm{ft} / \mathrm{min})$. An interpretation of the potential groundwater configuration of the surficial aquifer (Geraghty and Miller 1991) is shown in Fig. 15. The arrows in the figure suggest possible directions of groundwater flow. This figure also illustrates the influence on the surficial aquifer of topography and streams, which produce groundwater mounds and discharge zones, respectively, in the groundwater surface. Other studies in the vicinity of the K-25 site have suggested that strong geologic controls can influence the direction of groundwater flow (Saylor et al. 1990). Vertical components of flow may hydraulically link the surficial aquifer with the bedrock below (Geraghty and Miller 1989). 


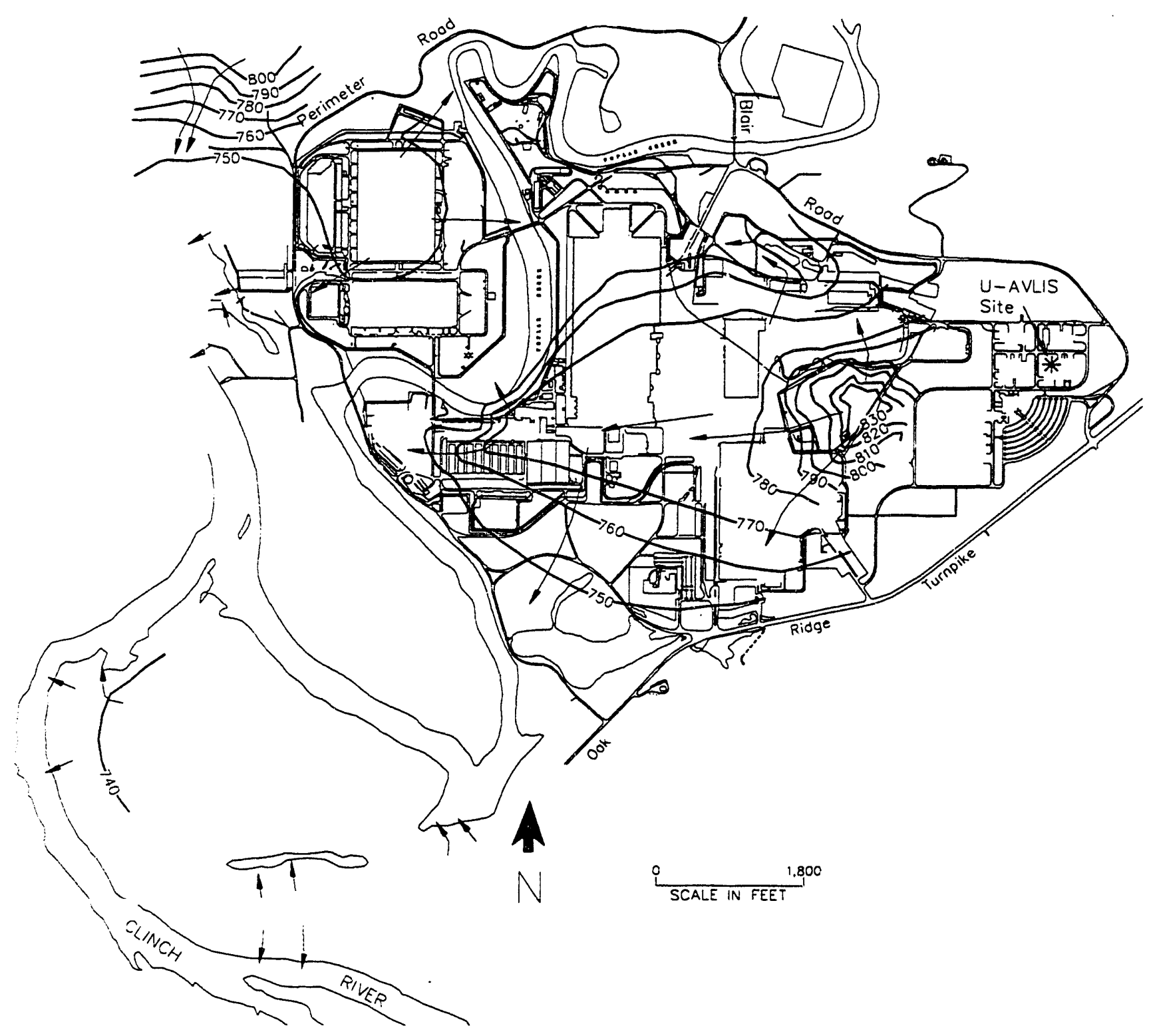

FIGURE 15 Contours of the Water Table and Inferred Groundwater Flow Paths in the Surficial Aquifer, K-25 Site (Source: Geraghty and Miller 1991)

\subsubsection{Bedrock Aquifer}

In areas where the unconsolidated sediments are thin, the water table generally resides within the bedrock (Saylor et al. 1990). The bedrock units existing at the K-25 site are, in ascending order, Shady Dolomite, the Rome Formation, and the Conasauga, Knox, and Chickamauga groups. These lithologic units are discussed in Sec. 2.1. Several permeability tests have been performed on the bedrock found at K-25 (Geraghty and Miller 1989). The results of these tests indicate that permeabilities for the bedrock units range from $10^{-5}$ to $10^{-3} \mathrm{ft} / \mathrm{min}$. Figure 16 illustrates an interpretation of the potential surface within the bedrock aquifer at the K-25 site. Because strong geologic influences are thought to exist within the bedrock aquifer, the 


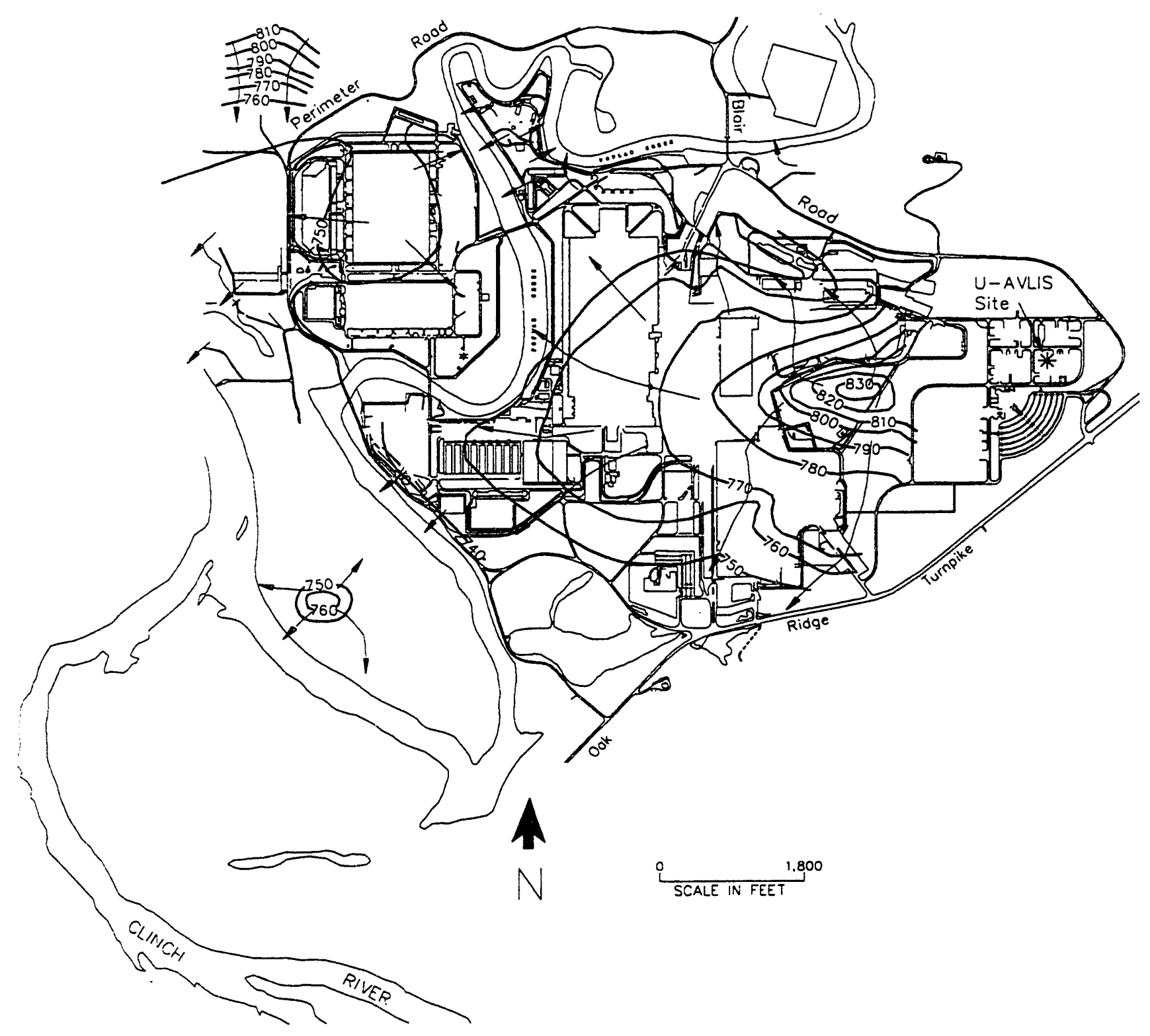

FIGURE 16 Contours of the Potentiometric Surface and Inferred Groundwater Flow Paths in the Bedrock Aquifer (Source: Geraghty and Miller 1991)

arrows in Fig. 16 can only indicate possible directions of groundwater flow. Vertical components of flow may exist in the bedrock aquifer, hydraulically linking it with the sediments above (Geraghty and Miller 1989).

\subsubsection{Groundwater Quality}

Kornegay et al. (1990) describe the 41 solid waste management units (SWMUs) identified at K-25. These 41 SWMUs have been grouped into 14 distinct sites. Figure 17 presents the locations of the sites. A groundwater monitoring program has been initiated at K-25 to characterize 


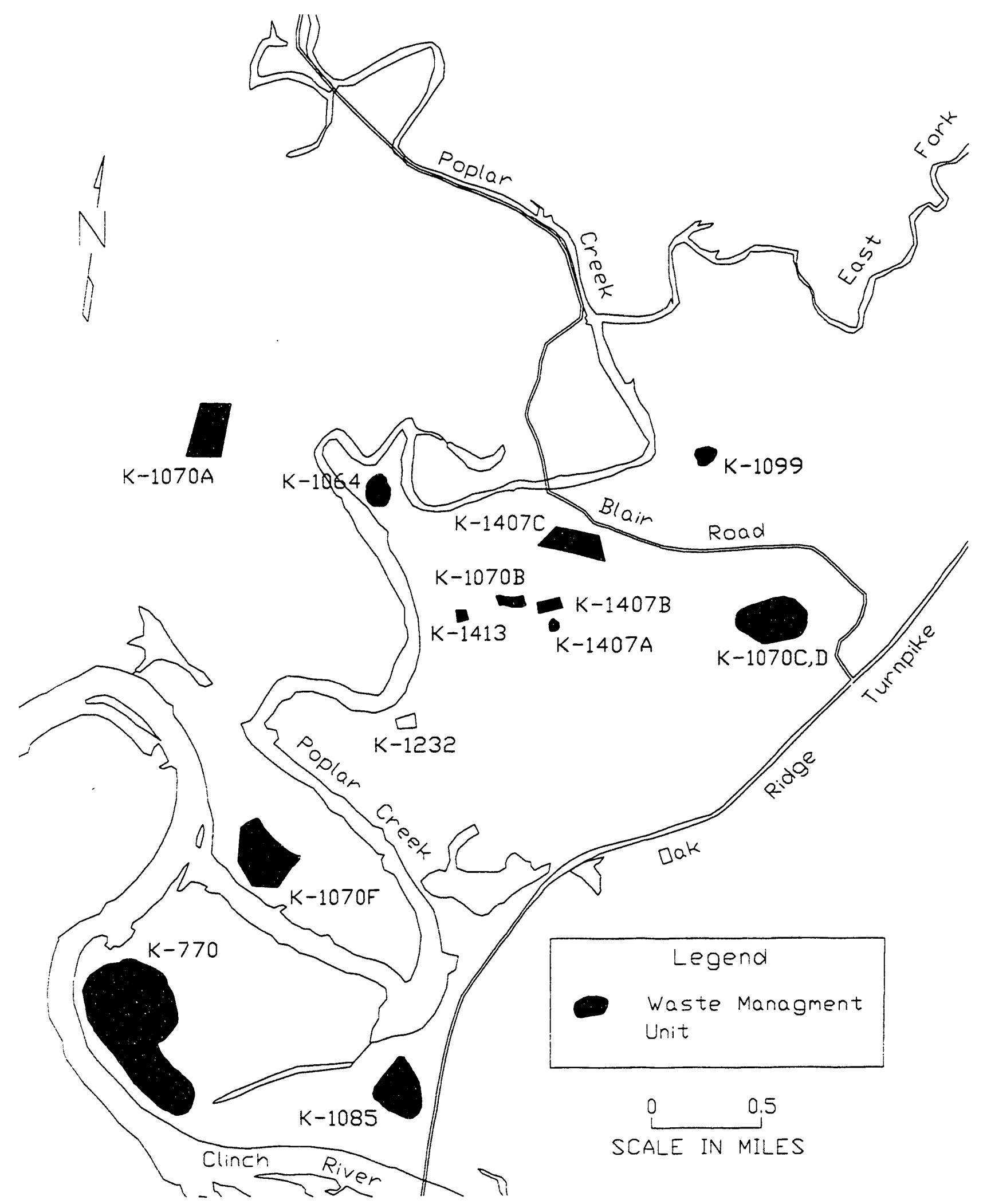

FIGURE 17 Location of the Groups of Solid Waste Management Units (Source: Kornegay et al. 1990) 
the impact of the 41 sites on groundwater resources (Fig. 17). Groundwater samples obtained from the monitoring wells were analyzed for radiological and nonradiological contaminants. At various sites, several contaminants were detected and determined to have concentrations larger than acceptable limits. Among the contaminants are trichloroethylene, carbon tetrachloride, lead, manganese, cadmium, chromium, and alpha activity. A detailed description of the type and extent of contamination found at K-25 is contained in Kornegay et al. (1990).

\subsubsection{Water Regulations}

A 1988 DOE directive on environmental safety and health (DOE Order 5400.1) mandaies that DOE facilities comply with all appropriate federal and state regulations. Under extenuating circumstances, DOE facilities may apply for exemption from DOE Order 5400.1. The national interim primary drinking water standards (40 CFR 141) set forth a maximum contaminant level (MCL) for each of several chemicals. These MCLs are enforceable federal standards that are also applicable to remedial action alternatives at hazardous and toxic waste sites. A detailed description of the federal regulations applicable to K-25 has been published (Kornegay et al. 1990).

\subsection{Land Use, Recreation, and Visual Resources}

\subsubsection{Land Use}

The ORR occupies a valley between the Cumberland Mountains and southern ranges of the Appalachian Mountains. The Great Smoky Mountains are located approximately 60 mi southeast of the reservation. The reservation lies within the corporate boundaries of the city of Oak Ridge, west and south of the city's population concentrations (see Fig. 18). Most of the city is located in Anderson County. The Clinch River forms the southern ORR boundary.

Since 1984, through an agreement with DOE, the Tennessee Wildlife Resources Agency (TWRA) has been responsible for wildlife management on the reservation (Saylor et al. 1990). The TWRA furnishes one full-time officer whose salary is remitted to the state by the DOE. Until 1986, selective logging took place at the ORR.

In addition to Roane and Anderson, the study area includes Knox, Loudon, an 1 Morgan counties. The most common land uses occurring in the area are commercial forest land and agriculture. Approximately $65 \%$ of the land within a 5-mi radius of the proposed site is woodland (Saylor et al. 1990). The remaining 35\% is made up of small farms, cattle pastures, and scattered residences. The nearest concentration of residences occurs almost 2 mi west of the proposed K-25 site. The closest residential areas of Oak Ridge lie 6 mi northeast of K-25.

In 1989, Anderson County had 124,000 acres, or $57.1 \%$ of its total land area, dedicated to forest lands. Agricultural land uses accounted for $18.6 \%$ (40,472 acres) of the county (see Table 6). Almost $3 \%(6,250$ acres) of the county is in residential use, and almost all of the development occurring in the privately owned sectors of the major urban areas is dedicated to residential land uses. 


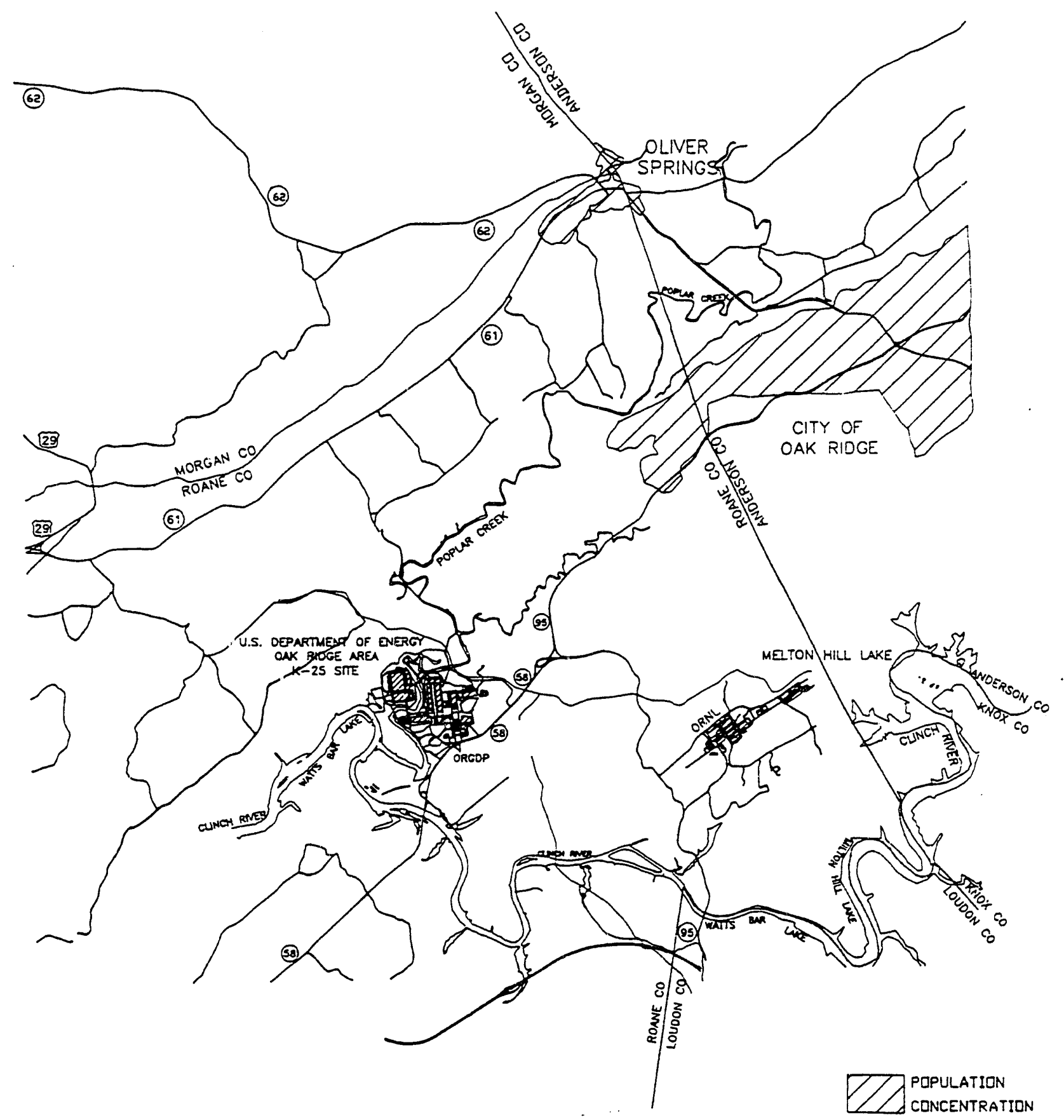

FIGURE 18 K-25 Site and Proximity to Population Centers 
TABLE 6 Selected Land Uses in the Study Area, 1989

\begin{tabular}{|c|c|c|c|c|}
\hline County & $\begin{array}{c}\text { Total Land } \\
\text { Areaa } \\
\text { (acres) }\end{array}$ & $\begin{array}{l}\text { Land in } \\
\text { Farms }^{b} \\
\text { (acres) }\end{array}$ & $\begin{array}{c}\text { Number } \\
\text { of } \\
\text { Farms }^{b}\end{array}$ & $\begin{array}{l}\text { Forest } \\
\text { Land } \\
\text { (acres) }\end{array}$ \\
\hline Anderson & 216,800 & 40,472 & 463 & 124,000 \\
\hline Knox & 323,800 & 94,701 & 1,253 & 127,500 \\
\hline Loudon & 150,500 & 77,665 & 760 & 62,300 \\
\hline Morgan & 334,500 & 43,960 & 304 & 287,800 \\
\hline Roane & 228,300 & 58,739 & 542 & 153,100 \\
\hline
\end{tabular}

aSource: CBER 1991.

bSource: USBC 1987.

Knox County led the study area in the proportion of land dedicated to residential uses in $1989(21.6 \%)$. The dominant land use in the county was forest, which accounted for $39 \%$ (127,500 acres) of the land. Agricultural land totaled 94,701 acres (29\%). Almost 40,000 acres $(12 \%)$ of Knox County were considered vacant land. Waterways make up 3.3\% (10,795 acres) of the county, while industrial uses accounted for almost $1 \%$ (3,342 acres).

More than $50 \%$ (77,665 acres) of Loudon County was used for agriculture in 1989. Forest lands made up $41 \%(62,300$ acres) of the county. Less than $1 \%$ (approximately 1,200 acres) of the county was used for residential purposes.

Morgan County, with the largest land area but smallest population in the study area, was the least developed in 1989. It had over 285,000 acres $(86 \%)$ of its land dedicated to forest land. Almost 44,000 acres (13\%) were used in agriculture.

Roane County's major land uses in 1989 were forest land and agriculture. Forests and woodlands comprised 153,100 acres $(67 \%)$ of the county's land, while agricultural uses accounted for 58,739 acres (26\%). Approximately $20 \%$ of the land in Roane County is owned by the federal government.

Land use within $5 \mathrm{mi}$ of the K-25 site is depicted in Fig. 19. The figure includes parts of four counties in the five-county study area; only Knox County is not represented in the plot of land use.

Several TVA electric transmission line corridors and a gas pipeline owned by the East Tennessee Natural Gas Company (ETNGC) run through sections of the study area. Several TVA lines enter the ORR from the west and northwest. The ETNGC pipeline enters the ORR from the north, runs southeast along a stretch of Blair Road under a section of the proposed site, and exits the ORR running east into Oak Ridge along the south side of Bethel Valley Road. 


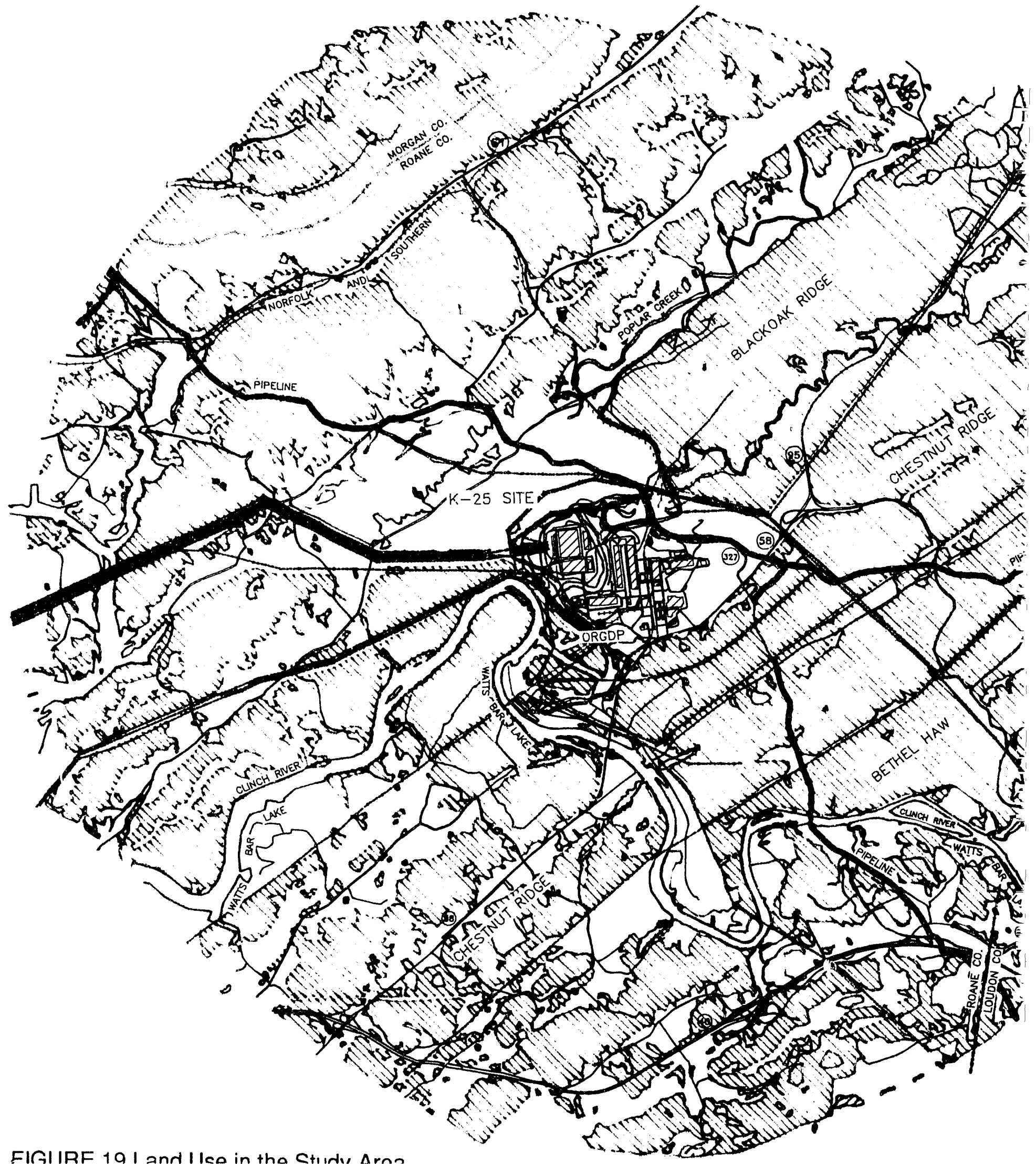

F!GURE 19 Land Use in the Study Area 


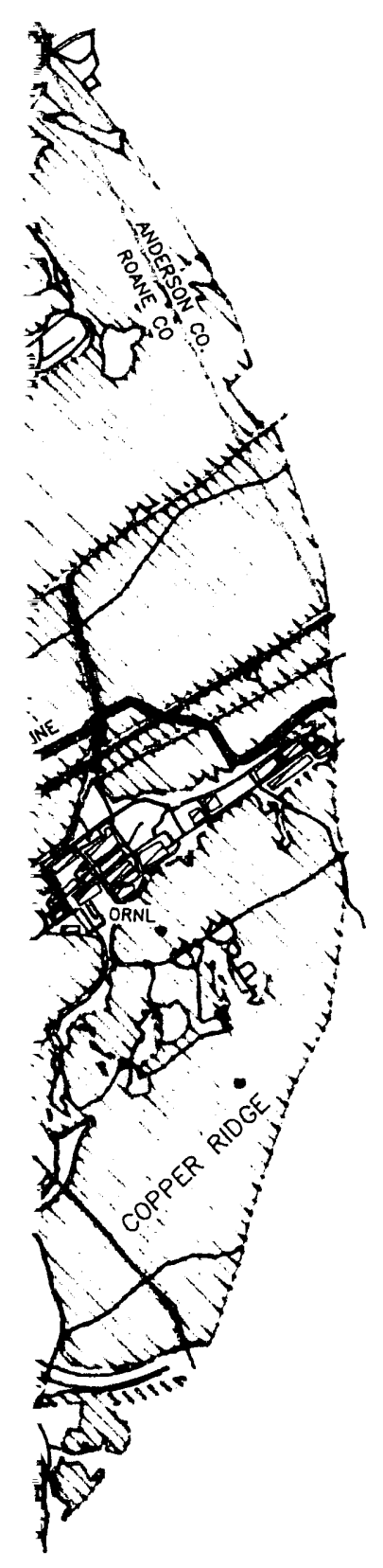

Legend

$\square$ Agriculture

E...... Woodland's

- County Esorders

- Pipeline

Ham Railroad

- Transmission 
There are no military bases in the study area, although two units of the Tennessee National Guard operate out of armories in Knoxville and Harriman. The Guard also maintains a training center in Oak Ridge.

Two counties in the study area have developed comprehensive plans. The Anderson County plan was developed in 1982. The Knoxville-Knox County General Plan was revised in 1986 (KKCMPC 1986). Oak Ridge has a comprehensive plan that was updated in 1988.

\subsubsection{Minerals and Mining Actlvity}

Coal, limestone, dolomite, clay and shale, zinc ore (sphalerite), sandstone, calcium carbonate, marble, gas, and oil are present or extracted in the five-county study area (TDC 1991).

Prominent rock types found in Anderson County include coal, limestone, dolomite, sandstone, and clay. Bituminous coal is mined in the county, as well as limestone and dolomite (as crushed stone) and clay/shale (for brick production). In Knox County, limestone, dolomite, and shale are the most common minerals, although calcium carbonate, zinc ore, and clay are recoverable. While no longer extracted, terrazzo marble was mined in the past. Present mining operations extract crushed stone (limestone and dolomite) and clay (TDG 1987). Morgan County contains coal, oil and gas, sandstone, clay, and shale. Sandstone and clay have extraction potential, but only coal, oil, and gas are presently recovered. Loudon County has reserves of limestone, dolomite, clay, calcium carbonate, terrazzo marble, and barite. Only barite and limestone/dolomite are now mined. Although limestone, dolomite, coal, shale, sandstone, and clay are the prominent rock types in Roane County, only bituminous coal and limestone are mined there now.

\subsubsection{Recreational Resources}

Recreational opportunities within a 2 -h drive of the ORR include boating, fishing, camping, hiking, hang-gliding, canoeing, kayaking, white water rafting, and skiing. Great Smoky Mountains National Park, the Cherokee National Forest, and the Ocoee River Recreation Area form a contiguous chain of recreational variety that begins approximately $80 \mathrm{mi}$ southwest of Oak Ridge and runs northeast along the North Carolina border into Virginia. The resort town of Gatlinburg, nestled in the north-central region of Great Smoky Mountains National Park, is $61 \mathrm{mi}$ from Oak Ridge. The Big South Fork National River and Recreation Area lies approximately 65 mi northwest of Oak Ridge. The Chickamauga and Chattanooga National Military Park is located just south of Chattanooga, approximately $100 \mathrm{mi}$ from Oak Ridge. Lookout Mountain, a former Civil War battle site, offers hang-gliding and is located a few miles south of Chattanooga. The TVA system of dams has created numerous lakes and recreational areas throughout the study area and adjacent counties. Most of these lakes offer fishing and boating opportunities and picnic areas. Melton Hill Lake, just south of Oak Ridge, is just one example. Several state parks and recreational areas are located within a $75-\mathrm{mi}$ radius of the ORR. Table 7 identifies state parks/recreational areas in the study area and adjacent counties. 
TABLE 7 State Parks and Recreation Areas within the Study Area and Adjacent Counties

\begin{tabular}{llr}
\hline $\begin{array}{c}\text { Name of Park } \\
\text { Recreation Area }\end{array}$ & \multicolumn{1}{c}{ County } & Acres \\
\hline Big Ridge & Union & 3,642 \\
Cove Lake & Campbell & 673 \\
Cumberland & Cumberland & 1,562 \\
Mountain & Campbell & 90 \\
Cumberland Trail & Monroe & 407 \\
Fort Loudon & Morgan & 11,651 \\
Frozen Head & Campbell & 213 \\
Indian Mountain & Anderson & 4,038 \\
Norris Dam & & \\
\hline
\end{tabular}

Source: CBER 1991.

Urban areas within the study area offer a variety of recreational opportunities and facilities. Knox County has approximately 40 recreation centers, 50 athletic fields, and 146 tennis courts (Saylor et al. 1990). Knoxville offers 34 parks, 8 public golf courses, and several public swimming pools. The county's parks and recreation department, in conjunction with Knoxville, issued a 5-yr plan in recent years (KCPRD 1988). In Oak Ridge, 7 athletic fields, 6 parks, 2 swimming pools, and 2 public golf courses complement several school playgrounds. Some of Oak Ridge's parks offer lakeside picnic areas and trails. Roane County features several parks, 9 swimming pools, and 5 golf courses. Several highways within $60 \mathrm{mi}$ of the ORR are statedesignated scenic parkways. These include State Highway 58, running southwest out of Oak Ridge into Kingston; State Highway 33, running north out of Knoxville; and U.S. 321, running southeast out of Lenoir City into Maryville.

Managed deer hunts, usually lasting no more than two days and supervised by the TWRA, are occasionally permitted on unrestricted portions of the ORR.

\subsubsection{Transportation Network}

The study area is surrounded by a well-developed transportation network (see Fig. 20) that includes three interstate highways, several U.S. and state highways, two major rail lines, the Clinch River, and a regional airport. 


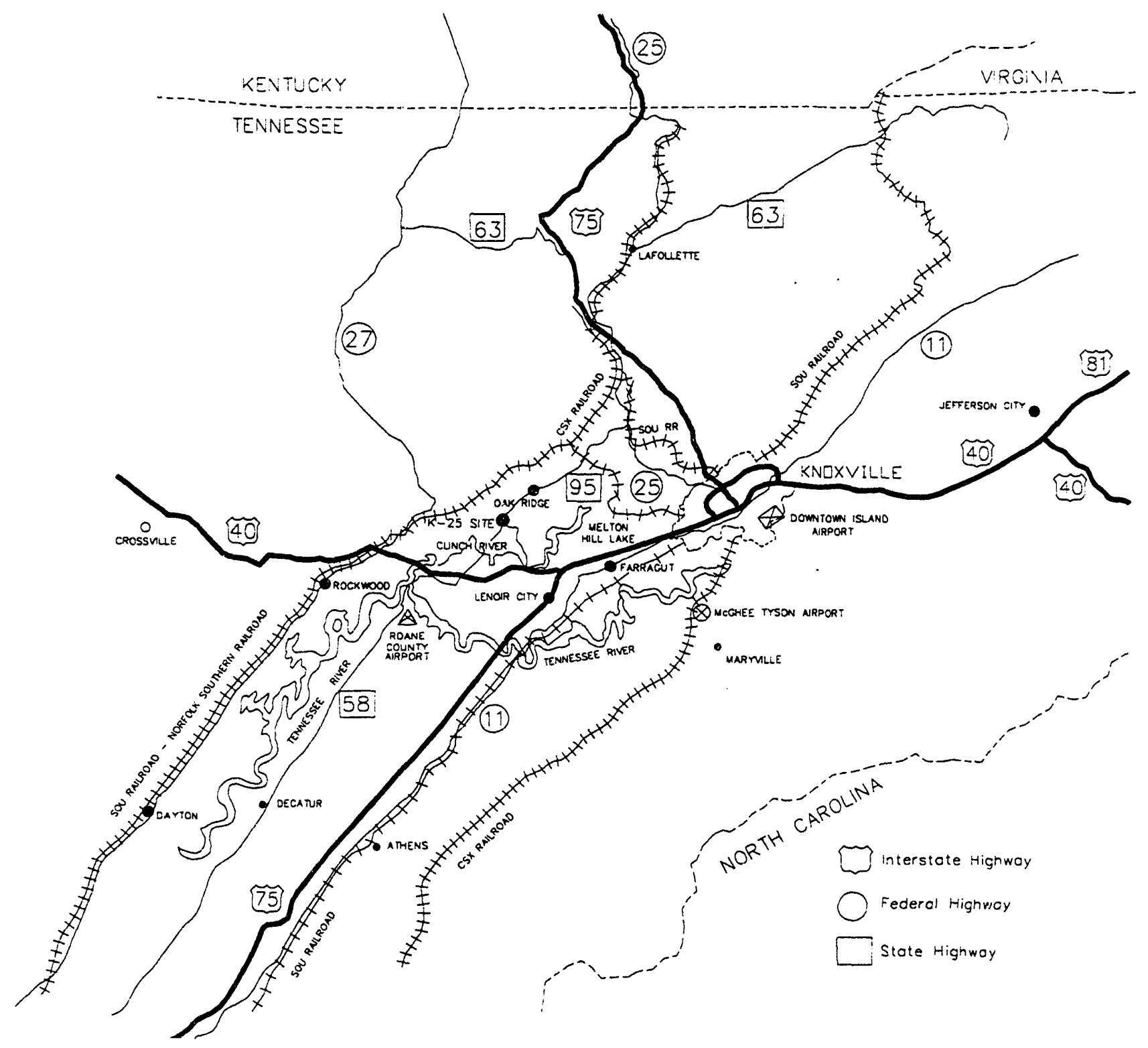

FIGURE 20 Regional Transportation Network

Interstate 40, an east/west artery running through Knoxville, Nashville, and Memphis, passes within $2 \mathrm{mi}$ of the ORR (Martin Marietta 1991). Interstate 40 interchanges with State Highway 95 about $5 \mathrm{mi}$ from the ORR. Interstate 75 runs north from Florida, Atlanta, and Chattanooga, before passing through Knoxville. Interstate 81 begins approximately $30 \mathrm{mi}$ northeast of Knoxville and runs into Virginia.

Several U.S. and state highways support the study area. U.S. 11 runs northeast out of Oak Ridge and southeast toward Chattanooga. U.S. 27, running north-south through Kentucky and Tennessee, passes just west of Oak Ridge. Northeastern Tennessee and southeastern Kentucky can be accessed by U.S. 25, out of Knoxville. State Highway 95 runs east-west through Oak 
Ridge along the northern border of the ORR. State Route 58, which passes through the reservation, runs southwest-northeast from Kingston, in Roane County, into Oak Ridge. State Route 58 is a state-designated scenic parkway. Table 8 presents the road types and their respective mileage totals for each study-area county.

Rail service in the study area is provided by the Norfolk Southern and CSX Transportation. The CSX moves between 20 and 30 trains per day through the study area, while Knoxville is a major hub for the Norfolk Southern.

The Clinch River is not presently used for transport by the ORR but has potential as an alternate route for moving the large machinery and support materials that the new facility would require (Martin Marietta 1991). The study area's regional airport, McGhee Tyson, is located approximately $13 \mathrm{mi}$ south of Knoxville. Delta, United, and US Air provide commercial air service. Knoxville also has a municipal airport, Downtown Island Airport, but it does not offer commercial air service.

\subsubsection{Visual Resources}

A complete inventory of visual resources for the proposed U-AVLIS site at K-25 does not exist. The reservation's proximity to the surrounding mountains places it in the background (over $3 \mathrm{mi}$ ) or distant background (over $5 \mathrm{mi}$ ) of several surrounding viewing areas or vistas.

TABLE 8 Mileage Total, by Road Type, for Each Study-Area County

\begin{tabular}{lrcccc}
\hline County & Total $^{\mathrm{a}}$ & $\begin{array}{c}\text { Inter- } \\
\text { state } \\
\text { System }\end{array}$ & $\begin{array}{c}\text { State } \\
\text { Highways }\end{array}$ & $\begin{array}{c}\text { County } \\
\text { Roads }\end{array}$ & $\begin{array}{c}\text { City } \\
\text { Streets }\end{array}$ \\
\hline Anderson & 810 & 12 & 127 & 421 & 248 \\
Knox & 2,580 & 59 & 226 & 1,397 & 896 \\
Loudon & 650 & 23 & 81 & 452 & 90 \\
Morgan & 573 & 0 & 108 & 448 & 15 \\
Roane & 929 & 23 & 128 & 603 & 175 \\
\hline
\end{tabular}

aslight differences between certain totals and the sum of the mileage constituents are due to rounding.

Source: CBER 1991. 


\subsection{Biotic Resources}

This section describes the biotic resources of the ORR, with emphasis on those components that might be affected by construction and operation of the U-AVLIS facility in the K25 area. The ORR is located within the Eastern Deciduous Forest region at the boundary between the Mixed Mesophytic Forest Section and the Appalachian Oak Forest Section (Galvin 1979). Species characterizing mixed mesophytic forest include beech, yellow poplar, basswood, sugar maple, sweet buckeye, red oak, white oak, and hemlock. (Scientific names of these and other plant and animal species are presented in Appendix A.) Hickories (e.g., shagbark and bitternut), red maple, white ash, and black walnut are among other tree species associated with this forest type. Understory trees include blackgum, sourwood, flowering dogwood, magnolia, redbud, hophornbeam, holly, and serviceberry. Shrub species include spicebush, witch-hazel, pawpaw, and alternate-leaved dogwood. The Appalachian Oak Forest is generally dominated by several rpecies of oaks (e.g., chestnut, red, white, black, and scarlet) (Galvin 1979).

Several additional descriptions of the ecological resources of the ORR have been published (Exxon 1976; PMC/TVA/ERDA 1977; USDOE 1979 and 1982; Loar et al. 1981; Boyle et al. 1982).

\subsubsection{Terrestrial Resources}

Because of its size and topographic complexity, the ORR supports a variety of plant communities. On ridges and dry slopes, oak-hickory forest predominates. This forest type is dominated by several species of oak (chestnut, black, red, and white) and of hickory (shagbark and bitternut). Yellow poplar, sugar maple, beech, white ash, and buckeye predominate in coves (cooler, moister valleys or steep north-facing lower slopes). Cove vegetation is not common on the ORR. Along streams and rivers, the cove vegetation gradually gives way to forest stands dominated by such flood-iolerant species as green ash, boxelder, elm, and sycamore.

During settlement, much of the original forest was cleared and the land converted to agriculture. Since establishment of the ORR in 1942, former agricultural fields developed into mixed pine forests through succession or were planted with pines (Saylor et al. 1990). Many of the pine plantations are managed.

From 1965 to 1986 , much of the ORR was selectively logged. Logged areas and many abandoned fields have been replanted with pines (e.g., loblolly, white, shortleaf, and Virginia pines) (Saylor et al. 1990).

Small cedar barrens also occur on the ORR, especially on shallow limestone soils (Saylor et al. 1990). This type of vegetation is dominated by prairie species and other drought-tolerant plants. Dominant species include grasses (e.g., little bluestem and dropseed), forbs, eastern red cedar, and stunted oaks. Several species of rare plants also occur in the barrens (see Sec. 2.6.3).

Common amphibians residing on the ORR include upland chorus frog, northern spring peeper, American toad, bullfrog, and gray treefrog. Common reptiles include eastern box turtle, 
painted turtle, snapping turtle, northern ringneck snake, worm snake, ground skink, five-lined skink, and eastern fence lizard (Saylor et al. 1990).

More than 170 species of birds potentially occur on the ORR (Sayior et al. 1990). Common raptors include black and turkey vultures, red-tailed and broad-winged hawks, and the screech owl. Upland gamebirds commonly observed include quail, mourning dove, and ruffed grouse. Numerous songbird species are coinmon during niigration periods (Saylor et al. 1990).

Waterfowl (ducks, herons, and shorebirds) are common on the ORR. The most commonly observed species include Canada geese, wood ducks, black ducks, gadwalls, and mallards (Kornegay et al. 1990). One of the areas most extensively used by Canada geese is the K-25 area, where most geese are probably residents (Kornegay et al. 1990). Many waterfowl are observed along the Clinch River, its backwaters, and in ponds. Two great blue heron rookeries are located on Poplar Creek, north of the K-25 site (Cunningham and Pounds 1991).

More than 50 species of manmals may occur on the ORR. Common game species and furbearers include white-tailed deer, eastern cottontail rabbit, eastern gray squirrel, woodchuck, striped skunk, raccoon, red fox, and muskrat. The bobcat, gray fox, long-tailed weasel, mink, and beaver also reside on the ORR. White-footed and golden mice are the most prevalent small mammals. Because of the high incidence of deer/vehicle collisions on the ORR, undeveloped areas have been under a wildlife management agreement with the TWRA. This agreement allows for deer hunting on unrestricted portions of the ORR in order to reduce the reservation's deer population (Sayior et al. 1990). Eastern wild turkeys have also been introduced on the ORR by the TWRA in recent years.

The proposed U-AVLIS site is a 200 -acre wooded tract of DOE-owned land at the eastern end of the K-25 area and is bounded by the Oak Ridge Turnpike (State Highway 58) and Blair Road. No biotic inventory of this tract has been completed. It is former pine plantation (loblolly, with some white pine), with many pines dying and being replaced by hardwood species such as oak, sugar maple, red maple, yellow poplar, and elm. Common understory species include Japanese honeysuckle, dogwood, poison ivy, black cherry, and blackberry.

A number of high quality natural areas occur near the proposed U-AVLIS site. These include a mature beech-maple forest and a beech-mixed oak forest approximately $1.2 \mathrm{mi}$ southeast of the site. Both stands contain several uncommon spring-flowering plant species, including Appalachian bugbane, a federal Category 2 species. Perhaps the best example in the state of a cedar barrens occurs across the Clinch River from the K-25 site. This barrens has been designated a State Natural Area. The Blackoak Ridge bluffs, on the Clinch River about $2.5 \mathrm{mi}$ west of the K-25 site, support two federally listed Category 2 plant species: false foxglove and Appalachian bugbane.

\subsubsection{Wetlands}

At least 90 sites on the ORR support wetland vegetation (Cunningham and Pounds 1991). The majority occur as (1) embayments of Melton Hill Reservoir and Watts Bar Lake (i.e., Clinch River) bordering the ORR; (2) forested wetlands along Poplar Creek, East Fork Poplar Creek, 
Bear Creek, and their tributaries; (3) old farm ponds; and (4) wet areas associated with streams and seeps (Cunningham and Pounds 1991).

According to the U.S. Fish and Wildlife Service National Wetlands Inventory Map, the only wetlands in the vicinity of the proposed U-AVLIS site are open-water areas that are permanently flooded owing to artificial impoundments (Saylor et al. 1990). A small bottomland hardwood forest dominated by large hackberry, silver maple, and elm occurs directly east of Blair Road, within a few hundred meters of the proposed construction site, but this forest is not included in the National Wetlands Inventory Map. Furthermore, an extensive inventory by Cunningham and Pounds (1991) has revealed numerous wetlands in the vicinity of K-25, including three small wetland areas along the stretch of Mitchell Branch that occurs near the U-AVLIS site.

\subsubsection{Aquatic Resources}

There are numerous streams, ponds, and settling basins on the ORR (Kornegay et al. 1990; Saylor et al. 1990). The Clinch River borders the ORR and the K-25 site to the west. Poplar Creek and its tributaries (East Fork Poplar Creek, Bear Creek, and Mitchell Branch) flow through the K-25 area, near the proposed U-AVLIS site. Two holding ponds (K-1007-B and K-901-A) are located on the K-25 site and discharge into the Clinch River.

In a 1981 survey of three Clinch River sites near K-25, 26 fish species were collected (Saylor et al. 1990, from Loar et al. 1981). Of the 326 individuals collected by gill-netting and electroshocking, the most common species were gizzard shad (24\% of total), bluegill (24\%), and largemouth bass $(9.5 \%)$. Less common species included white bass, skipjack herring, sauger, and redbreast sunfish.

A similar survey of Poplar Creek yielded 545 individuals from 28 species. By far the most common species was gizzard shad (43\% of total). The only other species accounting for more than $10 \%$ of the total caught was white bass $(12 \%)$. Other species included bluegill $(6 \%)$ and white crappie (5\%).

The only fish present in Mitchell Branch were the blacknose dace, creek chub, and redbreast sunfish. All three species are pollution tolerant (Saylor et al. 1990). The depressed species richness is likely due to environmental stress caused by K-25 site effluent discharged to this stream, including elevated levels of residual chlorine detected in 1986-1987 (Saylor et al. 1990).

No recent studies of the other biotic communities of the Clinch River, Poplar Creek, and Mitchell Branch have been completed. In the early 1980s, the phytoplankton in the Clinch River in the vicinity of the K-25 site was dominated by diatoms. Occasional blooms of green and bluegreen algae were also noted (Saylor et al. 1990). Because of upstream hypolimnetic discharges from Melton Hill Dam, the cool temperature in the Clinch River may limit phytoplankton production (Saylor et al. 1990). The benthic fauna of the Clinch River is dominated by oligochaetes and dipterans. Rotifers account for more than $85 \%$ of the zooplankton in the river. Densities of zooplankton in Poplar Creek are substantially lower than those in the Clinch River because of the creek's swift current, lack of productive backwater areas, and low primary production. 


\subsubsection{Threatened and Endangered Species}

No plant species on federal or state threatened and endangered lists, including species of special concern, are known to occur at the proposed U-AVLIS site (Winford 1991). False foxglove and Appalachian bugbane, which are federally listed Category 2 species, have recently been found at two sites along Poplar Crcek adjacent to K-25, one of them about 1 mi northwest and the other about $1 \mathrm{mi}$ west of the proposed U-AVLIS site (Cunningham and Pounds 1991). False foxglove has also been reported from the Clinch River shoreline (Watts Bar Lake) just downstream of K-25 (Cunningham and Pounds 1991). Purple fringeless orchis, a state threatened plant, occurs in a wetland just south of the visitors overlook along a power line right-of-way adjacent to the south boundary of K-25, about $1 \mathrm{mi}$ from the proposed U-AVLIS site, and in several areas southeast of K-25 along Bear Creek and its tributaries (Cunningham and Pounds 1991). Other federally listed species may occur in the area (Winford 1991), and several state-listed plants are also known to occur on the ORR (see Table 9).

Sightings of the federally endangered eastern cougar have been reported from the ORR (Saylor et al. 1990). Federally endangered gray bats have been reported flying over Johnson Creek west of the K-25 site, and Indiana bats (federally endangered) have been observed on the ORR (Saylor et al. 1990). No state-listed mammals have been reported. The southeastern shrew, listed by the TWRA as being in need of management, occurs on the ORR.

The bald eagle, on the federal endangered list, has been observed foraging along the Clinch River. The peregrine falcon and red-cockaded woodpecker, also federally endangered, could occur on the ORR based on the species' ranges; however, no suitable habitat has been identified for either species. The red-cockaded woodpecker has been reported within $15 \mathrm{mi}$ of the K-25 site. Bachman's sparrow, a federal Category 2 species, has been known to nest on the ORR; suitable habitat for this species (open pine woods with shrubs and dense ground cover) occurs on the ORR. Several state-listed species have also been observed on or near the K-25 site (Table 9).

No federally listed amphibians or reptiles are known to occur in the vicinity of the proposed U-AVLIS site; however, several state-listed species occur within $5 \mathrm{mi}$ (Table 9). One fish on the federal threatened list, the slender chub, could occur in the vicinity of the proposed U-AVLIS site (Winford 1991). No federally listed aquatic species have been identified in the immediate U-AVLIS area (Saylor et al. 1990). Several mollusks on federal and state endangered lists could occur in the area (Winford 1991), although these have not been collected since at least 1950 (Saylor et al. 1990).

\subsection{Cultural Resources}

\subsubsection{Regional Prehistory and History}

The prehistory and history of a region provide the requisite context for evaluation of its archaeological sites and historic structures. The following is a description of the prehistory and history of eastern Tennessee, the location of the ORR. 
TABLE 9 Threatened, Endangered, or Special-Interest Species that Occur or May Occur within 5 mi of K-25

\begin{tabular}{|c|c|c|}
\hline \multirow[b]{2}{*}{ Species } & \multicolumn{2}{|c|}{ Status ${ }^{a}$} \\
\hline & Federal & State \\
\hline \multicolumn{3}{|l|}{ PLANTS } \\
\hline $\begin{array}{l}\text { False foxglove (Aureolaria patula) } \\
\text { Sedge (Carex oxylepis var. pubescens) }\end{array}$ & $\mathrm{C2}$ & $\begin{array}{l}T \\
S\end{array}$ \\
\hline Appalachian bugbane (Cimifuga rubifolia) ${ }^{b}$ & $\mathrm{C} 2$ & $T$ \\
\hline Tall larkspur (Delphinium exaltatum) $)^{\mathrm{b}}$ & $\mathrm{C} 2$ & $E$ \\
\hline Goldseal (Hydrastis canadensis) ${ }^{b}$ & & $T$ \\
\hline Slender blazing star (Liatris cylindracea) & & $E$ \\
\hline $\begin{array}{l}\text { Canada lity (Lifium canadense) } \\
\text { Gattinaer's lobelia (Lobelia apoendiculata }\end{array}$ & & $\mathrm{T}$ \\
\hline $\begin{array}{l}\text { Gattinger's lobelia (Lobelia appendiculata } \\
\text { var. gattingeri) }\end{array}$ & $\mathrm{C} 2$ & \\
\hline American ginseng (Panax quinquefolia) ${ }^{b}$ & & $T$ \\
\hline $\begin{array}{l}\text { American hart's tongue fern (Phyllitis } \\
\text { scolopendrium var. americana) }\end{array}$ & $\mathrm{T}$ & \\
\hline Southern rein-orchid (Platanthera flava) ${ }^{b}$ & & S \\
\hline $\begin{array}{l}\text { Purple fringeless orchis (Platanthera } \\
\text { peramoena) }^{\mathrm{b}}\end{array}$ & & $\mathrm{T}$ \\
\hline Wharton's blackberry (Rubus whartoniae) & $\mathrm{C} 2$ & \\
\hline & $\mathrm{C} 2$ & $\stackrel{S}{E}$ \\
\hline $\begin{array}{l}\text { Virginia spirea (Spirea virginiana) } \\
\text { Virnes) }\end{array}$ & PT & \\
\hline Earleaf foxglove (Tomanthera auriculata) & & $E$ \\
\hline \multicolumn{3}{|l|}{ MAMMALS } \\
\hline Indiana bat (Myotis sodalis) & $E$ & $E$ \\
\hline $\begin{array}{l}\text { Gray bat (Myotis grisescens) } \\
\text { Southeastern shrew (Sorex longirostris) }\end{array}$ & $E$ & $\underset{M}{M}$ \\
\hline $\begin{array}{l}\text { Southeastern shrew (Sorex longirostris) } \\
\text { Eastern cougar (Felis concolor) }\end{array}$ & $\mathrm{E}$ & \\
\hline Eastem woodrat (Neotoma floridana magister) & $\mathrm{C2}$ & \\
\hline \multicolumn{3}{|l|}{ BIRDS } \\
\hline Cooper's hawk (Accipiter cooperi) & & $T$ \\
\hline Sharp-shinned hawk (Accipiter striatus) & & $\mathrm{T}$ \\
\hline Bachman's sparrow (Aimophila aestivalis) ${ }^{b}$ & $\mathrm{C} 2$ & $E$ \\
\hline $\begin{array}{l}\text { Grasshopper sparrow (Ammodramus } \\
\text { savannarum) }\end{array}$ & & $\mathrm{T}$ \\
\hline Marsh hawk (Circus cyaneus) & & $\mathrm{T}$ \\
\hline Bald eagle (Haliaeetus leucocephalus) & $E$ & $\mathrm{E}$ \\
\hline $\begin{array}{l}\text { Black-crowned night heron (Nycticorax } \\
\text { nycticorax) }\end{array}$ & & M \\
\hline Osprey (Pandion haliaetus) & $E$ & $E$ \\
\hline $\begin{array}{l}\text { Red-cockaded woodpecker (Picoides } \\
\text { borealis) }\end{array}$ & $\mathrm{E}$ & $\mathrm{E}$ \\
\hline \multicolumn{3}{|l|}{ AMPHIBIANS AND REPTILES } \\
\hline $\begin{array}{l}\text { Six-lined racerunner (Cnemidophorus } \\
\text { sexlineatus) }\end{array}$ & & M \\
\hline Cumberland slider (Trachemys scripta troostii) & & M \\
\hline
\end{tabular}




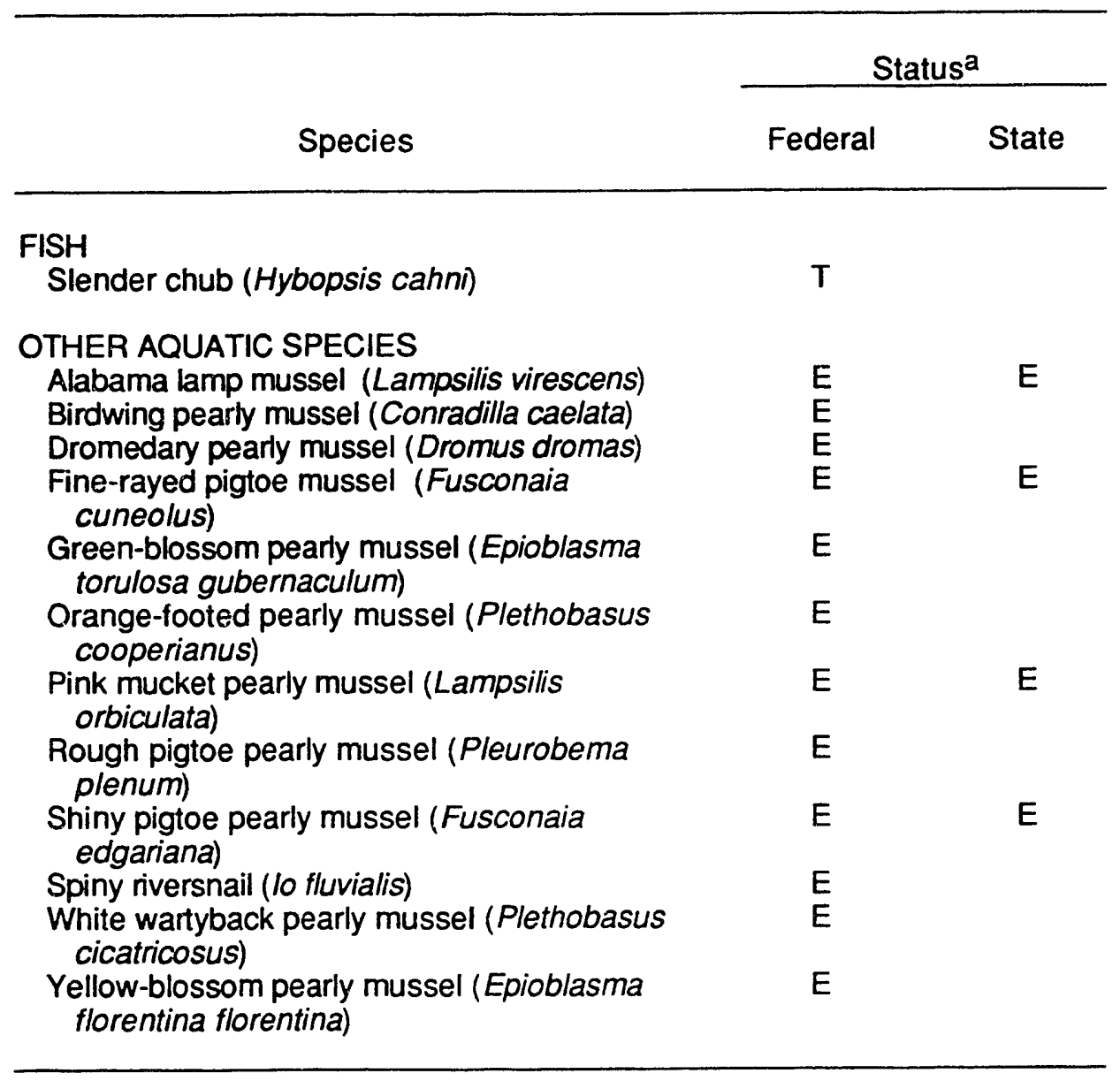

$\mathrm{aE}=$ endangered; $\mathrm{T}=$ threatened; $\mathrm{PT}=$ proposed for threatened status; $\mathrm{C} 2$ = Category 2, status under review; $S=$ special concern; $M=$ in need of management.

bobserved on the ORR.

Sources: Saylor et al. 1990; Cunningham and Pounds 1991; Winford 1991.

Early prehistoric settlement in the eastern Tennessee region is assigned to the Paleo-Indian period (9,000-6,000 B.C.). This period is characterized by small, highly mobile human populations that subsisted primarily on the hunting of big game animals and secondarily by the gathering of roots, nuts, and berries. The archaeological record of this period is primarily confined to isolated artifacts (Fielder 1974).

The Paleo-Indian period is followed by the Archaic period (6,000-100 B.C.) which is characterized by a gradual shift in the subsistence cycle to smaller-scale hunting and fishing and intensive gathering of wild plant foods. Settlement during this period was concentrated along major rivers and streams in eastern Tennessee (Fielder 1974). 
The Woodland period (100 B.C.-A.D. 1000) is represented by a number of significant cultural changes, as demonstrated in the archaeological record. Evidence for the first manufacture of ceramic vessels and for the early stages of horticulture appears in conjunction with continued evidence of hunting, fishing, and plant food gathering. There is also evidence for a long-distance trade economy during this period. Distinctive burial customs appeared at this time, as demonstrated by the widespread construction of earthen mounds in eastern Tennessee (Fielder 1974).

The Mississippian period (A.D. 1000-1700) consisted of large-scale, agriculturally based societies. These societies consisted of more complex economic and trade systems, as well as increased ceremonial mound building. The location of Mississippian villages suggests a permanent, year-round occupation; they were situated on the lower river and stream terraces, where the soil was most suitable for maize agriculture (Fielder 1974).

The Mississippian period is followed by the Protohistoric period (A.D. 1700-1838). When European settlers began arriving in eastern Tennessee, they encountered the Cherokee, descendants of the earlier prehistoric peoples in the region. The settlers found the Cherokee living in villages and practicing agriculture, hunting, fishing, and trading. The Oak Ridge area was inhabited by the Overhill Cherokee, who occupied the Tennessee River Valley in present-day Monroe County, Tennessee (Fielder 1974). This period represents the final phase of Native American occupation in eastern Tennessee. With the encroachment of white settlers into the area, the Cherokee way of life changed rapidly. The Cherokee groups chose to adopt much of the new way of life and incorporate it into their own traditional culture. However, the desire of the Euroamericans to possess Cherokee lands forced an end to any possible coexistence of the two groups. In 1838, the federal government forcibly moved the Cherokee to Oklahoma via the fateful "Trail of Tears" (Fielder 1974). Some Cherokee have since returned to and reside in western North Carolina on the Cherokee Reservation.

The first Euroamerican settlers in the Oak Ridge area were the French and English. For some time, the French traded with the Cherokee, establishing fairly benevolent relations with them. The English, however, wanting to acquire land holdings in the area, established Fort Loudon on the Tellico River in 1756; this also resulted in stopping the French incursion into the region. Descendants of these earliest Euroamerican settlers were still residing in the area when the U.S. Army Corps of Engineers purchased the land in 1942 for the Manhattan Project.

\subsubsection{Archaeological Sites and Historic Structures}

The ORR, located in eastern Tennessee, occupies portions of Anderson and Roane counties. The area is characterized by an extensive ridge-and-valley terrain and a drainage system dominated by the Clinch River and Poplar Creek. This area has been subject to human occupation for more than 10,000 years; evidence of prehistoric occupation is concentrated primarily along the Clinch River. The proposed U-AVLIS site is located near the eastern boundary of the K-25 site.

An archaeological survey was conducted in 1974 on the ORR (Fielder 1974). This survey was designed as a preliminary overview of prehistoric sites located within the reservation and did not entail a high-resolution sampling of all portions of the survey area. It is likely that the survey 
area contains additional sites (Fielder 1974). The survey did, however, document the existence of 45 prehistoric sites and several Euroamerican homesteads. Of these sites, each of the prehistoric periods discussed above, in Sec. 2.7.1, is represented. Included in the 45 are a Paleo-Indian site, 8 Archaic sites, 24 Woodland sites, and 5 Mississippian sites (Fielder 1974). Approximately 12 of the sites are located near K-25 (USDOE 1979).

Prior to 1972 , the ORR had not been surveyed for historic structures. Surveys were conducted for several proposed federal construction projects. These surveys identified sites specifically located within the proposed project boundaries of the Clinch River Breeder Reactor Plant, the Bear Creek Plant proposed by Exxon Nuclear Co., and the ORGDP (K-25) possible expansion area. A survey was also conducted for pre-1942 (pre-Manhattan Project) historic structures at the ORR in 1975. This survey encompassed areas on the ORR that had not been included in the previous surveys. The survey identified 415 historic sites; 41 are standing structures, and 46 are partially standing structures. The remaining sites were either foundations or scattered surface remains. One site, the Freels Log Cabin, is eligible for inclusion on the National Register of Historic Places (NRHP). Many of the other sites identified in this survey may also be eligible (Fielder et al. 1977). The foundation of a log barn (site 40RE136) is located at the southeast comer of the proposed U-AVLIS site (across Blair Road) and will require further investigation (Fielder 1974; Martin Marietta 1990). A list of historic structures included on the NRHP is presented in Appendix B.

The George Jones Memorial Baptist Church and Cemetery, established in 1901, is located north of Blair Road, less than $0.25 \mathrm{mi}$ from the north boundary of the proposed U-AVLIS site. The cemetery is currently accessible and will need to remain so for visitation purposes. Also located at the K-25 site are several buildings associated with the Manhattan Project. These buildings, nearly 50 years old, may be eligible for inclusion on the NRHP. The U-AVLIS proposed action would require the use of several of these buildings as support facilities.

\subsubsection{Native American Concerns}

The Cherokee Reservation is located in western North Carolina, approximately $60 \mathrm{mi}$ southeast of the ORR. Native American religious and cultural sites (including burials) are protected under the American Indian Religious Freedom Act. To date, no burial sites have been encountered within the ORR. No religious or sacred sites in current or recent use by Native American groups have been identified; consultations with the Cherokee may be necessary, however.

\subsection{Socioeconomic Factors}

\subsubsection{Population}

The proposed U-AVLIS production plant site is located in Roane County, with a population of 47,227 (USBC 1991) and falls within the boundaries of the city of Oak Ridge (population 27,310 ). The city stretches beyond Roane County into Anderson County (population 
68,250). The study area, consisting of Anderson, Roane, Morgan, Knox and Loudon counties, had a 1990 population of 499,781 , or approximately $10 \%$ of Tennessee's $4,877,185$ people. Knoxville, approximately $20 \mathrm{mi}$ east of the proposed site, had a 1990 population of 165,121 and is the largest city in the study area (CBER 1991).

The 1990 population of cities within a $25-\mathrm{mi}$ radius of the proposed site included Oliver Springs, 3,433 (8 mi north); Kingston, 4,552 (8.6 mi southwest); Harriman, 7,119 (9.3 mi west); Lenoir City, 6,147 (11.1 mi south); Farragut, 12,793 (13.6 mi southeast); and Clinton, 8,972 (16.7 mi northeast). The concentrations of people nearest the proposed site occur in two small unincorporated towns -- Dyllis, $1.8 \mathrm{mi}$ northwest, and Jonesville, $3.7 \mathrm{mi}$ north.

The population increased substantially in all five counties during the 1970 s, with the increases ranging from $11.7 \%$ in Anderson County to $26 \%$ in Loudon County (Martin Marietta 1990). During the 1980s, however, population growth rates declined in four of the five counties, with Roane County experiencing a population loss of 2.5\% (CBER 1991). Current and historical population data for the study area and the major urban centers within each county are presented in Table 10.

Population projections for the study area indicate substantial growth for Roane $(24.5 \%)$ and Morgan (18.6\%) counties by 2000 (ETDD 1991). Growth rates in Anderson (9.7\%) and Knox $(8.3 \%)$ counties are expected to produce moderate population increases by 2000 , while the

TABLE 10 Current and Historical Population Data for the Study Area

\begin{tabular}{|c|c|c|c|c|c|}
\hline \multirow{2}{*}{$\begin{array}{c}\text { County/ } \\
\text { City }\end{array}$} & \multicolumn{4}{|c|}{ Year } & \multirow{2}{*}{$\begin{array}{c}\% \\
\text { Change, } \\
1980-90\end{array}$} \\
\hline & 1960 & 1970 & 1980 & 1990 & \\
\hline $\begin{array}{l}\text { Anderson } \\
\text { Oak Ridge } \\
\text { Clinton }\end{array}$ & $\begin{array}{r}60,032 \\
27,169 \\
4,943\end{array}$ & $\begin{array}{r}60,300 \\
28,319 \\
4,794\end{array}$ & $\begin{array}{r}67,384 \\
27,662 \\
7,790\end{array}$ & $\begin{array}{r}68,250 \\
27,310 \\
8,972\end{array}$ & $\begin{array}{r}1.3 \\
-1.3 \\
15.2\end{array}$ \\
\hline $\begin{array}{l}\text { Knox } \\
\text { Knoxville } \\
\text { Farragut }\end{array}$ & $\begin{array}{r}250,523 \\
111,827 \\
a\end{array}$ & $\begin{array}{r}276,293 \\
174,587 \\
a\end{array}$ & $\begin{array}{r}319,694 \\
175,045 \\
6,279\end{array}$ & $\begin{array}{r}335,749 \\
165,121 \\
1 \%, 793\end{array}$ & $\begin{array}{r}5.0 \\
-5.7 \\
103.7\end{array}$ \\
\hline $\begin{array}{l}\text { Loudon } \\
\text { Lenoir City }\end{array}$ & $\begin{array}{r}23,757 \\
4,979\end{array}$ & $\begin{array}{r}24,266 \\
5,324\end{array}$ & $\begin{array}{r}28,553 \\
5,505\end{array}$ & $\begin{array}{r}31,255 \\
6,147\end{array}$ & $\begin{array}{r}9.5 \\
11.7\end{array}$ \\
\hline Morgan & 14,304 & 13,619 & 16,604 & 17,300 & 4.2 \\
\hline $\begin{array}{l}\text { Roane } \\
\text { Harniman } \\
\text { Kingston }\end{array}$ & $\begin{array}{r}39,133 \\
5,931 \\
2,010\end{array}$ & $\begin{array}{r}38,881 \\
8,734 \\
4,142\end{array}$ & $\begin{array}{r}48,425 \\
8,303 \\
4,561\end{array}$ & $\begin{array}{r}47,227 \\
7,119 \\
4,552\end{array}$ & $\begin{array}{r}-2.5 \\
-14.3 \\
-0.2\end{array}$ \\
\hline
\end{tabular}

aunincorporated.

Source: CBER 1991. 
growth rate for Loudon County is projected to be $3.4 \%$ by 2000 . Table 11 contains population projectionis to 2000 for the study area counties.

For a comprehensive discussion of population distribution and population projections for a 50-mi radius around the proposed site, see Martin Marietta (1990).

\subsubsection{Housing}

The five-county study area had 212,612 housing units in 1990, of which 197,472 were occupied (USBC 1991). The area had 15,140 vacant housing units, and rental apartment vacancy rates ranged from $2.0 \%$ in Loudon County to $9.3 \%$ in Anderson County (see Table 12). Owneroccupied housing accounts for $67.4 \%$ of occupied housing in the study area.

Anderson County's rental property includes efficiency, one-, two-, and three-bedroom apartments, single-family homes, and mobile homes. The rental vacancy rate was $9.3 \%$ in 1990 . The average monthly rent for a two-bedroom apartment was $\$ 390$ (ETDD 1991). In 1990, the median value of owner-occupied housing in Anderson County was $\$ 55,100$. Owners occupy $70.8 \%$ of all available housing in the county. There were 615 houses and mobile homes for sale in the county in 1989 (Saylor et al. 1990).

With the largest population in the study area, Knox County has the most housing available. There were 254 vacant apartments in 1990, and the rental vacancy rate was $4.6 \%$. The average monthly rent for a two-bedroom apartment was $\$ 420$, highest in the study area. Owner-occupied housing had a median value of $\$ 63,900$ in 1990 , when $63.9 \%$ of all available housing was occupied by owners. There were 1,465 mobile homes and houses on the market in 1989 .

TABLE 11 Population Projections for the Study Area to 2000

\begin{tabular}{lccccccc}
\hline & & \multicolumn{7}{c}{ Projection } \\
\cline { 3 - 7 } County & $\begin{array}{c}1990 \\
\text { Actual }\end{array}$ & 1996 & 1997 & 1998 & 1999 & 2000 & $\begin{array}{c}\text { Growth } \\
\text { Rate (\%), } \\
1990-2000\end{array}$ \\
\cline { 3 - 8 } Anderson & 68,250 & 73,380 & 73,715 & 74,069 & 74,451 & 74,852 & 9.7 \\
Knox & 335,749 & 353,250 & 355,519 & 357,990 & 360,667 & 363,539 & 8.3 \\
Loudon & 31,255 & 31,515 & 31,700 & 31,890 & 31,099 & 32,304 & 3.4 \\
Morgan & 17,300 & 19,601 & 19,821 & 20,045 & 20,277 & 20,520 & 18.6 \\
Roane & 47,227 & 56,516 & 57,065 & 57,627 & 58,210 & 58,793 & 24.5 \\
\hline
\end{tabular}

Source: ETDD 1991. 
TABLE 12 Housing Units in the Five-County Area and Apartment Vacancy Status, 1990

\begin{tabular}{lrrrrr}
\hline & \multicolumn{5}{c}{ Housing Indexes } \\
\cline { 2 - 6 } County & $\begin{array}{c}\text { Total } \\
\text { Units }\end{array}$ & $\begin{array}{c}\text { Total } \\
\text { Occupieda }\end{array}$ & $\begin{array}{c}\text { Owner- } \\
\text { Occupieda }\end{array}$ & $\begin{array}{c}\text { Renter- } \\
\text { Occupied }\end{array}$ & $\begin{array}{c}\text { Apartment } \\
\text { Vacancy } \\
\text { Rate (\%) }\end{array}$ \\
\hline Anderson & 29,323 & 27,384 & 19,401 & 7,983 & 9.3 \\
Knox & 143,582 & 133,639 & 85,369 & 48,270 & 4.6 \\
Loudon & 12,995 & 12,155 & 9,428 & 2,727 & 2.0 \\
Morgan & 6,378 & 5,841 & 4,844 & 997 & $\mathrm{n} / \mathrm{a}$ \\
Roane & 20,334 & 18,453 & 14,102 & 4,351 & 2.2 \\
\hline
\end{tabular}

aSource: USBC 1991.

bSource: ETDD 1991.

Loudon County had the lowest rental vacancy rate in the study area (2\%). The average monthly rent for a two-bedroom apartment was also the lowest of the five counties (\$249). Only a single apartment (out of 50 total) was vacant in 1990. The median value of owner-occupied housing was $\$ 51,000$ in 1990 , and 270 houses and mobile homes were for sale in 1989. Almost $78 \%$ of all available housing was occupied by owners in 1990.

In Morgan County, the median price of owner-occupied housing was $\$ 37,800$. The county had the highest owner-occupied housing (82.9\%) rate in the study area. One hundred and fifty houses and mobile homes were on the market in 1989.

In Roane County, only three apartments were available in 1990 , when the rental vacancy rate was $2.2 \%$. The average monthly rent for a two-bedroom apartment in that year was $\$ 309$. Owner-occupied housing accounted for $76.4 \%$ of all available housing in 1990 , and there were 430 houses and mobile homes for sale in 1989.

\subsubsection{Labor, Employment, and Income}

The number of people in the labor force in the study area in 1990 was 245,514 (ETDD 1991). The Knox County unemployment rate of $4.1 \%$ was the lowest of the five counties in 1990. Morgan County had the highest unemployment rate in the study area $(9.0 \%)$ that year (see Table 13). The state unemployment rate was 5.3\% in 1990 . Comprehensive labor and employment data for the study area can be found in publications of the East Tennessee Development District (ETDD 1991). 
TABLE 13 Employment and Income in the Study Area

\begin{tabular}{lrcr}
\hline County & $\begin{array}{c}1990 \\
\text { Labor } \\
\text { Force }\end{array}$ & $\begin{array}{c}1990 \\
\text { Unemployment } \\
\text { Rate }\end{array}$ & $\begin{array}{c}1988 \\
\text { Per-Capita } \\
\text { Income }\end{array}$ \\
\hline Anderson & 33,157 & $4.6 \%$ & $\$ 13,957$ \\
Knox & 163,003 & $4.1 \%$ & $\$ 15,560$ \\
Loudon & 16,036 & $5.3 \%$ & $\$ 14,941$ \\
Morgan & 6,607 & $9.0 \%$ & $\$ 8,724$ \\
Roane & 26,711 & $6.8 \%$ & $\$ 12,906$ \\
\hline
\end{tabular}

Source: ETDD 1991.

Three of the five counties in the study area had per-capita income levels above the state average of $\$ 13,867$ in 1988 . Knox County, with a 1988 per-capita income of $\$ 15,560$, led the study area. Morgan County's 1988 per-capita income of $\$ 8,724$, a figure representing $56 \%$ of the state average, was the lowest in the study area. Per-capita income in the study area between now and 2000 is expected to increase $1.5 \%$ annually (Saylor et al. 1990).

\subsubsection{Public and Community Services}

\subsubsection{Education}

The study area had 86,215 students enrolled in 305 public primary and secondary schools in 1989 (CBER 1991). Two vocational schools, five junior colleges, one four-year liberal arts college, and the main campus of the University of Tennessee serve the five-county area.

The Knox County School System, made up of 94 schools and 8 districts, is the largest in the study area. It enrolled 56,157 students and employed 3,337 teachers in 1989 (CBER 1991). The University of Tennessee and four of the area's junior colleges are located in Knoxville. Carson-Newman College is located in Jefferson City, approximately $25 \mathrm{mi}$ northeast of Knoxville.

Anderson County's public schools enrolled 12,582 students in 30 schools in 1989 (see Table 14). The Oak Ridge School System is the largest in the county, consisting of four elementary schools, two junior high schools and one high school (Saylor et al. 1990). 
TABLE 14 County Public School Statistics for the Study Area, Scholastic Year 1989

\begin{tabular}{lrcc}
\hline County & $\begin{array}{c}\text { Student } \\
\text { Enrollment }\end{array}$ & $\begin{array}{c}\text { Number of } \\
\text { Teachers }\end{array}$ & $\begin{array}{c}\text { Number of } \\
\text { Schools }\end{array}$ \\
\hline Anderson & 1,258 & 842 & 30 \\
Knox & 56,157 & 3,337 & 94 \\
Loudon & 5,735 & 326 & 151 \\
Morgan & 3,544 & 179 & 9 \\
Roane & 8,197 & 476 & 21 \\
\hline
\end{tabular}

Source: CBER 1991.

In Loudon County, 5,735 students attended 15 public schools in 1989. Public schools in Morgan County employed 179 teachers to instruct 3,544 students in the county's 9 schools during the 1989 school year. Roane County had 8,197 students attending 21 public schools in 1989.

\subsubsection{Police}

Police protection in the study area is provided by local city police forces, county sheriff's departments, and the Tennessee Highway Patrol. The Anderson County Sheriff's Department operates out of Clinton and employs 23 full-time officers. The Oak Ridge Police Department has 47 full-time members, while Clinton employs 14 full-time officers (Saylor et al. 1990). In Knox County, the Sheriff's Department employs 90 full-time officers; 278 full-time police officers work for the city of Knoxville.

Police protection in Morgan County is provided by the 10 full-time officers of the Sheriff's Department and 2 full-time members of the Wartburg Police Department. Roane County has 22 full-time officers employed in the Sheriff's Department. The police department in Harriman employs 18 full-time officers, and 8 officers work full time in Kingston. Rockwood's police department has 14 full-time officers. The Loudon County Sheriff's Department operates out of Loudon and employs 38 full-time officers. The city of Loudon has a full-time police force of 8 officers.

\subsubsection{Fire}

Fire protection in the five-county study area is mainly provided by volunteer departments. Four such departments serve Anderson County. The city of Oak Ridge has a full-time force of 
40 fire fighters operating out of three stations. The department has a small hazardous materials unit that consists of 6 trained fire fighters and some equipment. However, in the event of a mishap involving hazardous materials, the city has a mutual agreement with ORR to utilize trained specialists and equipment from emergency squads operating out of the K-25, Y-12, and ORNL sites. The Clinton Fire Department is staffed by 15 full-time fire fighters and 40 volunteers (Saylor et al. 1990).

Knoxville, with 330 full-time fire fighters, 93 vehicles, and 19 stations, has the largest fire department in the study area. The department has a trained, 12 -member hazardous materials team operating in three shifts around the clock. The team is equipped with an emergency response vehicle. In addition to the team, 10 of Knoxville's police officers are state-certified hazardous materials technicians. Knox County is served by the Rural Metro Fire Department, a force that operates outside the Knoxville city limits and is staffed by full-time and volunteer fire fighters. The county also has five volunteer departments.

City fire departments with full-time members in Roane County include Harriman (21 fulltime fire fighters), Rockwood (13 full-time), and Kingston (5 full-time). Five volunteer departments operate in the county as well. Morgan County has no full-time fire fighters but is served by nine volunteer departments. In Loudon County, fire protection is provided by the city fire departments of Loudon ( 7 full-time firefighters) and Lenoir City (6 full-time) and three volunteer departments.

\subsubsection{Health Care}

Health care is available in the study area through 13 hospitals, several nursing homes, 1,144 doctors, and 316 dentists (CBER 1991). A wide array of medical services can be found in Knoxville. The city has 8 hospitals, including the University Medical Center, a regional hospital serving all of eastern Tennessee (Saylor et al. 1990). The city has 12 nursing homes (1,200 beds), 2 community mental health centers, and a state mental health facility. There are 943 doctors and 235 dentists practicing in Knox County (see Table 15).

Anderson County's two hospitals are located in Oak Ridge and Clinton. Both cities have a nursing home as well. Kingston, in Roane County, has three nursing homes and one of the county's two hospitals. The other Roane County hospital is located in Rockwood, which also has a nursing home. Loudon County is served by one small hospital, 19 doctors, and 9 dentists. There are no hospitals in Morgan County, and all three of the county's doctors practice in Wartburg, a town with a 124-bed nursing home.

\subsubsection{Water}

The Clinch, Tennessee, and Little Tennessee river systems provide most of the study area's water. Knoxville has the largest public system in the study area, with a maximum capacity of 50 million gallons/day (mgd) and an average daily flow of $37 \mathrm{mgd}$ (Saylor et al. 1990). The Oak Ridge system has a 28 -mgd maximum capacity and an average daily flow rate (which includes DOE plants) of approximately $15 \mathrm{mgd}$. 
TABLE 15 Medical Resources in the Study Area, 1988-1990

\begin{tabular}{lcrcc}
\hline County & $\begin{array}{c}\text { Number of } \\
\text { Hospitals }\end{array}$ & $\begin{array}{c}\text { Number of } \\
\text { Beds }^{\mathrm{a}}\end{array}$ & $\begin{array}{c}\text { Number of } \\
\text { Doctors }\end{array}$ & $\begin{array}{c}\text { Number of } \\
\text { Dentists }\end{array}$ \\
\hline Anderson & 2 & 284 & 142 & 47 \\
Knox & 8 & 2,705 & 943 & 235 \\
Loudon & 1 & 30 & 19 & 9 \\
Morgan & 0 & 0 & 3 & 2 \\
Roane & 2 & 145 & 37 & 23 \\
\hline
\end{tabular}

$a_{1988 .}$

b1990.

Source: CBER 1991.

Roane County's public water systems include Harriman (3.5-mgd capacity, 1.4-mgd average daily flow); Rockwood (6-mgd capacity, 1.35-mgd average daily flow); and Kingston (2-mgd capacity, 0.35-mgd average daily flow). In Loudon County, Lenoir City and Loudon have public water systems (LCUB 1991). Loudon's water system has a capacity of $8 \mathrm{mgd}$. With an average daily flow of $4.5 \mathrm{mgd}$, the city is able to sell excess water to the Piney Utility District and nearby Philadelphia. The water system in Lenoir City has a designed capacity of $3 \mathrm{mgd}$ and an average daily flow of $1 \mathrm{mgd}$.

\subsubsection{Sewage}

Knoxville has the study area's highest sewage treatment capability, with a designed capacity of $80 \mathrm{mgd}$. Its average daily treatment volume is $37 \mathrm{mgd}$ (Saylor et al. 1990). In the early 1980s, Oak Ridge increased its treatment capacity with a new facility. An average sewage flow of $4.1 \mathrm{mgd}$ is treated, with a peak flow capacity of $8 \mathrm{mgd}$ and short-term capacity of $13 \mathrm{mgd}$.

Sewage treatment service is provided in Roane County by the cities of Harriman (2-mgd capacity, 0.9-mgd average daily volume); Rockwood (1.5-mgd capacity, 1.3-mgd average daily volume); and Kingston (0.51-mgd capacity, $0.46-\mathrm{mgd}$ average daily volume). Loudon and Lenoir City in Loudon County have sewage treatment facilities with respective capacities of 7.6 and $2 \mathrm{mgd}$. The system in Loudon has an average daily volume of $5 \mathrm{mgd}$, while Lenoir City's average daily volume of treated sewage is $0.9 \mathrm{mgd}$. 


\subsubsection{Electrical Power}

The TVA system of hydroelestric dams and coal-fired electric generating plants supplies the entire study area with electrical power. The TVA sells power from its massive grid to several utility boards, cooperatives, and city departments within the five-county region. The largest coalfired generating plants in the study area include the Kingston Steam Plant (Roane County), which has nine units and a maximum capacity of 1,700 megawatts (MW), and the single-unit Bull Run Steam Plant (Anderson County), with a maximum capacity of 950 MW (TVA 1991). The Norris Dam hydroelectric plant (Anderson County) has a maximum capacity of $100 \mathrm{MW}$. In Anderson County, electrical power is disiributed by the Clinton Utility Board and the city of Oak Ridge. The Knoxville Utilities Board oversees electricity distribution within the city and surrounding towns. Electrical power in Morgan County is administered by the Plateau Electric Cooperative. In Loudon County, the city of Loudon and the Fort Loudon Electric Cooperative are the chief electric utilities. The Harriman Utility Board and the Rockwood Electric Department are Roane County's largest electric utilities.

\subsubsection{Solid Waste Facilities}

Knoxville is the only municipality in the study area with a solid waste disposal plan (Saylor et al. 1990). Morgan County has a landfill, and Harriman, Rockwood, and Kingston use solid waste disposal facilities in Roane County. The Chestnut Ridge Landfill, located in Anderson County, disposes of solid waste from Oak Ridge. Chestnut Ridge is expected to reach capacity in 1996, although there is aciditional land adjacent to the existing landfill that is available for expansion.

\subsection{Waste Management}

The types of waste managed on the K-25 site include: (1) low-level radioactive waste, (2) hazardous waste, (3) mixed waste, (4) classified waste, (5) toxic waste, and (6) conventional solid waste. Waste management practices for each of these are presented in this section (Kornegay et al. 1990). Much of the waste stored or disposed of on-site is generated at other DOE facilities, such as the ORNL, the Y-12 site, the PORTS site, and the PGDP site. Production volumes for 1989 are provided in Table 16; wastes placed in storage in 1989 at K-25 from other DOE facilities are listed in Table 17; and off-site waste disposal activities are presented in Table 18.

\subsubsection{Low-Level Radioactive Waste}

Current decontamination activities result in the generation of solid and liquid low-level radioactive waste. This waste contains no hazardous materials and is regulated under DOE Order 5820.2A, Radioactive Waste Management. Low-level radioactive wastes generated at K-25 are presently stored in the K-305-5 low-level storage vault. Low-level wastes from ORNL and Y-12 are stored in the $K-310-2$ and $K-310-3$ vaults, respectively. A program to develop a new facility for the entire ORR for disposal of low-level radioactive waste is underway, and the expected year for the opening of such a facility is 1996 . 
TABLE 16 ORGDP Waste Placed in On-Site Storage in 1989

\begin{tabular}{|c|c|c|}
\hline Waste Description & Quantity & Ultimate Disposal \\
\hline Scrap metal (kg) & 175,650 & Under review \\
\hline PCB liquids (L) & 946 & TSCA incinerator \\
\hline PCB solids (kg) & 22,797 & TSCA incinerator \\
\hline Centrifuge sludge $(\mathrm{kg})$ & 19,772 & Under review \\
\hline Plating solutions (kg) & 363 & Shipped off-site \\
\hline Solvents (L) & 9,654 & TSCA incinerator \\
\hline Oils (L) & 52,801 & TSCA incinerator \\
\hline Laboratory waste (kg) & 31,679 & Under review \\
\hline Sludge from $K-1407-B / C$ ponds $(L)$ & $7,000,0,00$ & Delisting effort underway \\
\hline Photographic solutions (L) & 619 & ORNL for silver recovery \\
\hline Paint and aerosol contents (L) & 5,808 & TSCA incinerator \\
\hline TSCA ash (kg) & 16,892 & Under review \\
\hline TSCA sludge $(\mathrm{kg})$ & 23,380 & Under review \\
\hline Gas cylinders (kg) & 54 & Under review \\
\hline Metallic mercury $(\mathrm{kg})$ & 7 & Off-site recycle \\
\hline Solvent-contaminated rags $(\mathrm{kg})$ & 2,000 & TSCA incinerator \\
\hline Laundry sludge (kg) & 4738 & TSCA incinerator \\
\hline
\end{tabular}

Source: Kornegay et al. 1990. 
TABLE 17 Waste Placed in Storage at K-25 from Other DOE Facilities during 1989

\begin{tabular}{lrll}
\hline \multicolumn{1}{c}{ Waste Description } & Quantity & Ultimate Disposal \\
\hline Trichloroethane (L) & 3,812 & Blended, TSCA incinerator \\
Tetrachloroethylene (L) & 15,925 & Blended, TSCA incinerator \\
Metal sludges (kg) & 199,285 & Under review \\
Trichlorethylene (L) & 6,043 & TSCA incinerator \\
Waste oils/solvents (L) & 14,754 & TSCA incinerator \\
Nonhazardous waste (kg) & 3,600 & Under review \\
Acetonitrile (L) & 8,600 & Blended, TSCA incinerator \\
Mixed waste contaminated with lead $(\mathrm{L})$ & 20,414 & Under review \\
Waste solvent, mixed $(\mathrm{L})$ & 3,180 & Blended, TSCA incinerator \\
Mixed waste (kg) & 59,052 & Under review \\
Hazardous waste contaminated with metals $(\mathrm{kg})$ & 13,183 & Under review \\
Hazardous waste contaminated soils $(\mathrm{kg})$ & 16,044 & Under review \\
\hline
\end{tabular}

Source: Kornegay et al. 1990.

Low-level radioactively contaminated scrap metal is stored in the K-770 scrap metal storage facility. This material cannot be sold as scrap.

\subsubsection{Hazardous Waste}

Hazardous wastes are generated primarily as the result of cleaning and degreasing operations, and also from operations of the analytical laboratory. These wastes contain no radioactivity and are regulated under the Resource Conservation and Recovery Act (RCRA) and DOE Order 5400.3, Hazardous and Radioactive Mixed Waste Program. Flammable wastes are stored in the K-1420-A storage tank for eventual incineration. Additional waste oils, solvents, and organic materials awaiting incineration are stored in K-1425. Sludges, generated primarily at $\mathrm{Y}-12$, are stored in K-301-1 vault 4, K-305-6 vaults 19 and 19B, and K-306-1 vault 23A.

Eventual disposition of the hazardous waste is principally by incineration. 
TABLE 18 K-25 Off-Site Waste Disposal Activities during 1989

\begin{tabular}{lrl}
\hline \multicolumn{1}{c}{ Type of Waste } & Quantity & \multicolumn{1}{c}{ Ultimate Disposal } \\
\hline Nonradiological asbestos $(\mathrm{kg})$ & 33,400 & Y-12 plant landfill \\
Nonhazardous ( ${ }^{3}$ ) & 25,103 & Y-12 plant landfill \\
Nonradiological scrap metal (kg) & 129,655 & Sold to public \\
Batteries (kg) & 8,575 & Sold to public (recycle) \\
Film (kg) & 136 & Sold to public (recovery) \\
Chemicals (kg) & 227 & Sold to public \\
Office furniture, tires (kg) & 3,308 & Sold to public \\
Laboratory chemicals, janitorial & 11,762 & Commercial disposal facility \\
supplies (kg) & 908 & Sold to public \\
Scrap lumber (kg) & 14,240 & Sold to public \\
$\begin{array}{l}\text { Lead (kg) } \\
\text { Brass (kg) }\end{array}$ & 1,430 & Sold to public \\
\hline
\end{tabular}

Source: Kornegay et al. 1990.

\subsubsection{Mixed Waste}

Wastes that are contaminated with hazardous materials and also with uranium are typically generated as a result of decontamination of components that are contaminated with uranium. The majority of the mixed waste generated is in the form of a sludge containing low levels of uranium and technetium, together with cadmium and lead in leachable forms. Mixed wastes are also regulated under DOE Order 5400.3, Hazardous and Radioactive Mixed Waste Program.

Large quantities of hazardous radioactive sludges are treated at the K-1419 sludge fixation facility. The waste is mixed with concrete and stored aboveground at K-1417. Mixed waste is also stored in K-1425, awaiting incineration in K-1435, a TSCA incinerator.

\subsubsection{Classified Waste}

Classified wastes are generated by equipment and materials used in the gaseous diffusion plant that are classified confidential or secret pursuant to the Atomic Energy Act. They are also generated by cilassified information media such as magnetic disks, tapes, and ciassified documentis. This waste is regulated under DOE Order 5632.1A, Protection Program Operations. The current 
classified waste burial ground (K-1070-C) is closed. Classified wastes are temporarily stored onsite in secure storage areas.

\subsubsection{Toxic Waste}

Nonradioactive PCBs are regulated under TSCA. The PCBs are found in dielectric fluids used in electrical equipment and ventilation duct gaskets. All PCB-contaminated radioactive and nonradioactive wastes are stored in drums in the K-726 and K-306-1 PCB storage facilities, awaiting incineration in the TSCA incinerator.

Removal and disposal of nonradioactive asbestos are regulated under the Clean Air Act. Sources of asbestos are insulation around water and steam lines and heat-related processes. Nonradioactive asbestos waste is disposed of in the Y-12 plant landfill.

\subsubsection{Conventional Solid Waste}

Conventional solid waste consists of nonradioactive, nonhazardous, nontoxic solid wastes. Material consisting of fly ash from burning coal for heating and processing, sanitary waste from cafeteria and site administration, sterilized medical and infectious waste from the medical facility, construction spoils from ongoing construction activities, and demolition debris are disposed of in the Y-12 plant sanitary landfill.

Nonradioactive scrap metal is stored at the K-770 clean scrap yard for eventual sale to the public. Commercially discarded products and chemicals are stored in $\mathrm{K}-1025-\mathrm{C}$ for eventual sale to the public. 


\section{Additional Information Needs}

\subsection{Geology}

Additional soil data, describing the location and extent of the various soil types, are required.

\subsection{Air Resources}

Personnel at the K-25 site are obtaining the following data for later incorporation into the EIS to be prepared:

1. Mobile source emissions for the year 1990 , by pollutant, and

2. Ambient background information from the 1990 Environmental Surveillance Report. This report has been completed but awaits DOE approval. Current values for ambient background data will change when the new data are made available. Some background ambient data reported by the state of Tennessee for 1990 are now used. In the future, all background information will use the latest year -- 1990.

\subsection{Noise}

An on-site noise survey similar to the one carried out at the PORTS is underway.

\subsection{Water Resources}

More information describing local and regional floodplains must be obtained, as well as flooding events (500- and 100-yr events). Very little information describing regional groundwater flow is available. At the present time, no data describe local quantities of groundwater recharge or the location of local or regional groundwater recharge areas. In addition, the lithologic units most important to groundwater recharge (and hence important for environmental protection) are not identified. Groundwater velocities at the K-25 site should be determined and used to interpret groundwater flow and transport. The complexities resulting from the strong geologic control of groundwater flow direction should be included. Additional data should be obtained, at the proposed location of the U-AVLIS site, for the groundwater potential map. Information describing Tennessee water regulations as they pertain to the K-25 site should also be obtained. 


\subsection{Land Use, Recreation, and Visual Resources}

Land use interpretation and classification will require the most current satellite imagery data. Any recent land use analyses, studies, or updates conducted by counties or other units of government within the study area will be necessary. Information concerning residential land uses, even in relatively small communities, will be essential. Complete traffic counts for all the roads and arteries in the immediate vicinity of K-25 will be needed.

A visual resource inventory has to be completed for the immediate vicinity of the ORR. Outside resources, such as the U.S. Forest Service, may need to be involved.

\subsection{Biotic Resources}

In order to assess the full potential of biotic impacts resulting from the construction and operation of the U-AVLIS facility at the K-25 site, additional data are needed. These data include (1) quantitative vegetation and wildlife data (relative abundances and population estimates) for the proposed U-AVLIS site; (2) surveys to assess the population status of species in the threatened or endangered categories (on federal or state lists) for the U-AVLIS site and its vicinity; (3) TVA's impingement and entrainment data from the Clinch River in the vicinity of the K-25 site; (4) recent quantitative data (relative abundances and populations estimates) on the aquatic biota in the streams; (5) proposed means to clear and grade the proposed U-AVLIS site; (6) estimates of number of nests or breeding pairs of great blue herons in the two rookeries on Poplar Creek and their distance from the proposed U-AVLIS site; (7) survey for nests of black-crowned night heron in the vicinity of the K-25 site; (8) distance from the proposed U-AVLIS site of bald eagle activities; and (9) verification by the U.S. Army Corps of Engineers that no jurisdictional wetlands occur on the site (Federal Interagency Committee for Wetland Delineation 1989).

\subsection{Cultural Resources}

In order to determine whether there will be any adverse impacts on cultural resources at Oak Ridge associated with the proposed U-AVLIS project, an archaeological survey will probably be necessary; the decision will be made by the Tennessee Historical Commission. The area under consideration is heavily wooded; because of great variations in elevation, the project will require up to $90-\mathrm{ft}$ cuts to level the land for construistion. It is likely that archaeological sites will be present within the proposed U-AVLIS area, but the number of sites and their possible significance (i.e., eligibility for the NRHP) are difficult to predict on the basis of existing data. The Tennessee Historical Commission should be cortacted concerning the proposed action, if an EIS for the proposed U-AVLIS site is to be prepared. Consultation with this commission will determine whether a survey is necessary and will satisfy the requirements of Section 106 of the National Historic Preservation Act of 1966. The areas of concern are the possible existence of previously unrecorded archaeological sites and the pntential NRHP eligibility of a number of structures to be used in the proposed U-AVLIS project as support facilities; also, further investigation of historic structure 40RE136 probably will be necessary. 


\subsection{Socioeconomic Factors}

The most current population data pertaining to the area circumscribed by a 50 -mi radius around K-25, compiled in sector format, will be needed. Comprehensive educational data for the study area will be necessary, since the ESD's latest enrollment figures are from 1989. Complete data for 1990 should be available. The most current data concerning agriculture and commercial forestry will be needed as well. Some of the service-related data (police, health care, water, and sewage) were not reliable or comprehensive enough for an EIS -- there were many inconsistencies, and some of the existing data were inaccurate. The data should come from the source of the service, and the information should be the most current available. More complete information concerning solid waste management districts and facilities will also be necessary, along with data concerning local tax structures. Current employment data, broken down by occupational sector, will be necessary for each of the counties in the study area. For housing analysis, more detailed information regarding hotel/motel accommodations in the study area will be needed.

\subsection{Waste Management}

The quantity of waste generated varies substantially from year to year. As the capacity of existing waste storage facilities is reached, new facilities will be required. The waste management plan and waste inventory must be updated to remain current. 


\section{Potential Environmental Impacts}

Detailed analysis of the environmental impacts of constructing and operating a U-AVLIS production plant at the K-25 site cannot be provided before completion of the conceptual design, including site-specific data on construction, storage, and assembly sites. In this section, a short qualitative discussion of the potential environmental impacts that might be expected from a $U$ AVLIS production plant at the site is provided. Examples of impacts expected to be minimal are also indicated.

\subsection{Geology}

Construction and operation of the U-AVLIS production plant are not expected to cause any impacts on geological resources at the site.

\subsection{Air Resources}

It is not expected that air quality impacts from the construction and operation of the U-AVLIS production plant will exceed Tennessee regulations, National Ambient Air Quality Standards, or maximum allowable increments under the Prevention of Significant Deterioration (PSD) rules. There are guidelines currently in use by the state of Tennessee relating to new emissions of toxic air pollutants. It is expected that the U-AVLIS facility will meet them as well. Distances to the site boundary are comparatively large, emissions are expected to be small, and estimated background levels of pollutants at the site are not close to the standards at this time. Only when actual emission estimates for the proposed U-AVLIS production plant operation become available can the above statements be verified, but ozone may be an exception in this regard. Ozone is a secondary pollutant formed by photochemical reactions involving hydrocarbons and oxides of nitrogen. Relationships between plant emissions and ambient air concentrations of ozone cannot be accurately quantified at this time.

\subsection{Noise}

Noise levels at residences nearest to the $\mathrm{K}-25$ site are low, and noise emissions from $\mathrm{K}-25$ cannot be identified at the residential locations. Traffic noise from passing cars is the major noise source at the residences. No state or local regulations apply. It is not expected that U-AVLIS noise sources will be significant except for the proposed cooling tower and transformers. However, there may be temporary noise impacts brought on by additional traffic related to construction material deliveries and commuting construction workers. Noise problems are not expected, but final judgment is reserved until the conceptual design is made available. Ambient levels are very low, so the noise source term from U-AVLIS must be studied carefully. 


\subsection{Water Resources}

Discharges resulting from construction and operation of a U-AVLIS production plant at $\mathrm{K}-25$ could degrade local surface water and groundwater quality.

\subsection{Land Use, Recreation, and Visual Resources}

The proposed facility's location on the K-25 site of the ORR should have minimal impacts on land use and recreation. No surrounding land would be significantly altered, and no farmland would be taken out of production. Recreational resources in the area are developed enough to accommodate any increase in user demand brought about by construction and operation.

While the regional transportation network is well developed, traffic on roads and highways in and around ORR would increase with construction and operation. Based on daily traffic counts and calculations conducted by the Tennessee Department of Transportation, traffic problems could be encountered on Scarboro Road, State Highway 62, Bethel Valley Road, and Bear Creek Road, particularly at intersections.

The area's visual resources should not be significantly affected by the proposed U-AVLIS facility, since it will be located on an already dedicated site. Visual impacts should be limited to cooling tower plume effects associated with operation of the facility. Although many scenic areas and vistas surround the $\mathrm{K}-25$ site, the proposed facility would reside in the background (3-5 $\mathrm{mi}$ ) or distant background (over $5 \mathrm{mi}$ ) for most of them.

\subsection{Biotic Resources}

If U-AVLIS facilities are built at the proposed location, several permanent environmental impacts would result. Approximately 200 acres of mixed pine forest would be lost, along with the resident wildlife. If no other suitable and available habitat exists, some species populations would be lost permanently from the immediate area. Other species or individuals would be displaced, if suitable unoccupied habitat occurs within their dispersal range.

Temporary impacts that could occur as a result of the construction process include damage to vegetation from operation of construction machinery (e.g., collisions with trees that damage cambium, heat from parked equipment, and spills of oil or fuel). Temporary impacts on wildlife could result from construction noise and activities.

Because of the undulating topography of the proposed construction site, the site would need to be leveled, requiring the use of fill material (from on-site or off-site sources). Alternatively, the site could be graded. At the present time, no means of leveling the site has been determined. Erosion of sediments into streams would therefore be a possible impact of construction activities. 
Because a number of species listed in federal and state threatened or endangered categories occur in the vicinity of the proposed site, impacts to these species are a concern. At present, the status of many threatened or endangered species in the vicinity of K-25 is not known.

Additional impacts from U-AVLIS operations can be anticipated, including impingement and entrainment of fish eggs and larvae at the cooling water intake structures and runoff from paved areas into streams.

\subsection{Cultural Resources}

At this time it is not possible to determine if there will be any adverse impacts on cultural resources as a result of constructing and operating a U-AVLIS production plant at $\mathrm{K}-25$.

\subsection{Socioeconomic Factors}

On the basis of a projected operating staff of 1,500 and a construction force of 800 (Martin Marietta 1990), socioeconomic impacts should be minimal. The area's housing market can accommodate population increases associated with U-AVLIS. The study area's labor force, which lost over 4,000 jobs at the K-25 site alone during the 1980s, can easily handle the needs of U-AVLIS. Public services in the area are adequate and should not be overtaxed by U-AVLIS.

\subsection{Waste Management}

New waste management storage facilities might be required for waste generated by the proposed U-AVLIS facility at the K-25 site. Final disposal of waste off-site might require new storage or treatment facilities to be found. 


\section{References}

AEC (Atomic Energy Commission), 1972, Oak Ridge Operations, Oak Ridge, Tenn.

Boyle, J.W., et al., 1982, Environmental Analysis of the Operation of Oak Ridge National Laboratory (X-10 Site), Oak Ridge National Laboratory, ORNL-5870.

CBER (Center for Business and Economic Research), 1991, Tennessee Statistical Abstract, University of Tennessee, Knoxville.

Cunningham, M., and L. Pounds, 1991, unpublished information, provided to C. Dunn, Argonne National Labortory.

Dames and Moore, 1973, Seismic Design Criteria, Gaseous Diffusion Plants, Oak Ridge, TN, Paducah, $K Y$, and Portsmouth, OH, prepared for Union Carbide Corp., Nuclear Division, Oak Ridge, Tenn.

ETDD (East Tennessee Development District), 1991, Economic Statistics, Winter 1991, Knoxville.

Exxon Nuclear Co., 1976, Nuclear Fuel Recovery and Recycling Center Environmental Report, Docket 50564, Richland, Wash.

Federal Interagency Committee for Wetland Delineation, 1989, Federal Manual for Identifying and Delineating Jurisdictional Wetlands, a cooperative technical publication of the U.S. Army Corps of Engineers, U.S. Environmental Protection Agency, U.S. Fish and Wildlife Service, and U.S. Department of Agriculture Soil Conservation Service, Washington, D.C.

Fielder, G.F., Jr., 1974, Archaeological Survey with Emphasis on Prehistoric Sites of the Oak Ridge Reservation, Oak Ridge, Tennessee, Oak Ridge National Laboratory, ORNL/TM-4694.

Fielder, G.F., Jr., et al., 1977, Historic Sites Reconnaissance of the Oak Ridge Reservation, Oak Ridge, Tennessee, Oak Ridge National Laboratory, ORNL/TM-5811.

Galvin, M., 1979, Management of Transmission Line Rights-of-Way for Fish and Wildlife, Vol. 2, U.S. Fish and Wildlife Service, Biological Services Program, FWS/OBS-79/22.

Geraghty and Miller, Inc., 1989, Draft Revised Hydrology of the Oak Ridge Gaseous Diffusion Plant, Martin Marietta Energy Systems, Inc., Oak Ridge, Tenn.

Geraghty and Miller, Inc., 1991, Ground-Water Levels at the Oak Ridge K-25 Site, Martin Marietta Energy Systems, Inc., Oak Ridge, Tenn.,

Jackson, C.O., and C.W. Johnson, 1981, City Behind a Fence: Oak Ridge, Tennessee, 1942 1946, University of Tenriessee Press, Knoxville. 
KCPRD (Knox County Parks and Recreation Department), 1988, Five-Year Improvement Plan, Knoxville, Tenn.

Kennedy, R.P., et al., 1990, Design and Evaluation Guidelines for Department of Energy Facilities Subjected to Natural Phenomena Hazards, Lawrence Livermore National Laboratory, UCRL-15910.

KKCMPC (Knoxville-Knox County Metropolitan Planning Commission), 1986, General Plan, Knoxville, Tenn.

Kornegay, F.C., et al., 1990, Oak Ridge Reservation Environmental Report for 1989, Martin Marietta Energy Systems, Inc., ES/ESH/-13/V1.

LCUB (Loudon County Utility Board), 1991, personal correspondence with John Davis, Water Department Engineer, Loudon, Tenn. (Aug. 12).

Loar, J.M., et al., 1981, Technical Background Information for the ORNL Environmental and Safety Report: A Description of the Aquatic Ecology of White Oak Creek Watershed and the Clinch River below Melton Hill Dam, Oak Ridge National Laboratory, ORNL/TM-7509/V2.

Martin Marietta, 1990, U-AVLIS Site Data Package for the Oak Ridge K-25 Site, Martin Marietta Energy Systems, Inc., K-2067.

Martin Marietta, 1991, Oak Ridge Reservation Site Development and Facilities Utilization Plan 1990 Update, DOE/OR-885/RI.

Petrich, C.H., et al., 1984, Resource Management Plan for the U.S. Department of Energy Oak Ridge Reservation, Volume 7, Appendix G: Geography, Demography, Topography, and Soils, Oak Ridge National Laboratory, ORNL-6026/V7.

PMC/TVA/ERDA (Project Management Corp., Tennessee Valley Authority, and Energy Research and Development Administration), 1977, Final Environmental Statements Related to the Construction and Operation of the Clinch River Breeder Reactor Plant, prepared for U.S. Nuclear Regulatory Commission, NUREG-0139.

Rothschild, E.R., et al., 1984, Resource Management Plan for the Oak Ridge Reservation, Volume 10, Hydrology, Oak Ridge National Laboratory, ORNL-6026/V10.

Saylor, R.E., et al., 1990, Data Package for the Atomic Vapor Laser Isotope Separation (AVLIS) Plant Environmental Impact Statement, Oak Ridge National Laboratory, ORNL/TM-11482.

TDC (Tennessee Department of Conservation), 1991, letter from Greg Upham, Minerals Geologist, Nashville (July 24).

TDG (Tennessee Division of Geology), 1987, Directory of Tennessee Mining, Oil and Gas Operations, Nashville. 
TERA Corp., 1981, Seismic Hazard Analysis for Oak Ridge National Laboratory and the Paducah, Portsmouth, and FMPC Sites, Lawrence Livermore National Laboratory.

TVA (Tennessee Valley Authority), 1991, personal correspondence with Phillip Starck, Communications Coordinator, Knoxville (Sept. 6).

USBC (U.S. Bureau of the Census), 1987, Census of Agriculture, Washington, D.C.

USBC, 1991, Selected Population and Housing Characteristics: 1990, U.S. Department of Commerce, Washington, D.C.

USDOE (U.S. Department of Energy), 1979, Environmental Assessment of the Oak Ridge Gaseous Diffusion Plant Site, Oak Ridge, TN, DOE/EA-0106.

USDOE, 1982, Draft Environmental Impact Statement, Sale of Segment O of the Oak Ridge Reservation to the City of Oak Ridge, Tennessee, EIS-0094D.

U.S. Environmental Protection Agency, 1986, Quality Criteria for Water.

Winford, D.B., 1991, U.S. Fish and Wildlife Service, letter to C.P. Dunn, Argonne National Laboratory (Aug. 9).

Wolsko, T., et al., 1991, Site Evaluations for the Uranium-Atomic Vapor Laser Isotope Separation (U-AVLIS) Production Plant, Argonne National Laboratory, ANL/EAIS/TM-54 (July). 
Appendix A

Species Occurring on the K-25 Site 


\section{Appendix A \\ Species Occurring on the K-25 Site}

TABLE A.1 Names of K-25 Species, Other than Threatened and Endangered Species

\begin{tabular}{|c|c|}
\hline Common Name & Scientific Name \\
\hline \multicolumn{2}{|l|}{ PLANTS } \\
\hline $\begin{array}{l}\text { Alternate-leaved dogwood } \\
\text { Basswood } \\
\text { Beech } \\
\text { Bitternut hickory } \\
\text { Black cherry }\end{array}$ & $\begin{array}{l}\text { Cornus alternifolia } \\
\text { Tilia americana } \\
\text { Fagus grandifolia } \\
\text { Carya cordiformis } \\
\text { Prunus serotina }\end{array}$ \\
\hline $\begin{array}{l}\text { Black oak } \\
\text { Black walnut } \\
\text { Blackberry } \\
\text { Blackgum } \\
\text { Boxelder }\end{array}$ & $\begin{array}{l}\text { Quercus velutina } \\
\text { Juglans nigra } \\
\text { Rubus spp. } \\
\text { Nyssa sylvatica } \\
\text { Acer negundo }\end{array}$ \\
\hline $\begin{array}{l}\text { Chestnut oak } \\
\text { Dropseed } \\
\text { Eastern red cedar } \\
\text { Elm } \\
\text { Flowering dogwood }\end{array}$ & $\begin{array}{l}\text { Quercus prinus } \\
\text { Sporobolus sp. } \\
\text { Juniperus virginiana } \\
\text { Ulmus sp. } \\
\text { Cornus florida }\end{array}$ \\
\hline $\begin{array}{l}\text { Green ash } \\
\text { Hackberry } \\
\text { Hemlock } \\
\text { Holly } \\
\text { Hophornbean }\end{array}$ & $\begin{array}{l}\text { Fraxinus pennsylvanica } \\
\text { Celtis occidentalis } \\
\text { Tsuga canadensis } \\
\text { Ilex sp. } \\
\text { Carpinus caroliniana }\end{array}$ \\
\hline $\begin{array}{l}\text { Japanese honeysuckle } \\
\text { Littie bluestem } \\
\text { Loblolly pine } \\
\text { Magnolia } \\
\text { Pawpaw }\end{array}$ & $\begin{array}{l}\text { Lonicera japonica } \\
\text { Andropogon scoparius } \\
\text { Pinus taeda } \\
\text { Magnolia sp. } \\
\text { Asimina triloba }\end{array}$ \\
\hline $\begin{array}{l}\text { Poison ivy } \\
\text { Red maple } \\
\text { Red oak } \\
\text { Redbud } \\
\text { Scarlet oak }\end{array}$ & $\begin{array}{l}\text { Rhus radicans } \\
\text { Acer rubrum } \\
\text { Quercus rubra } \\
\text { Cercis canadensis } \\
\text { Quercus stellata }\end{array}$ \\
\hline
\end{tabular}


TABLE A.1 (Cont'd)

Common Name

Scientific Name

PLANTS (Cont'd)

Serviceberry

Shagbark hickory

Shortleaf pine

Silver maple

Spicebush

Sugar maple

Sweet buckeye

Sycamore

Virginia pine

White pine

Amelanchier arborea

Carya ovata

Pinus echinata

A.cer saccharinum

Lindera benzoin

White oak

White ash

Witch-hazel

Yellow poplar

Acer saccharum

Aesculus octandra

Platanus occidentalis

Pinus virginiana

Pinus strobus

Quercus alba

Fraxinus americana

Hamamelis virginiana

Liriodendron tulipifera

\section{AMPHIBIANS AND REPTIES}

American toad

Bullfrog

Eastern box turtle

Eastern fence lizard

Five-lined skink

Gray treefrog

Ground skink

Northern ringneck snake

Northern spring peeper

Painted turtle

Snapping turtle

Upland chorus frog

Worm snake

\section{FISH}

Blacknose dace

Bluegill

Creek chub

Gizzard shad

Largemouth bass
Bufo americanus Rana catesbeiana Terrapene carviina carolina Sceloporus undulatus

Eumeces fasciatus

Hyla cineara

Scincella lateralis

Diadophis punctatus edwardsi

Hyla crucifera crucifera

Chrysemys picta picta

Chelydra serpentina serpentina

Pseudacris triseriata feriarum

Carphophis amoenus amoenus

Rhinichthys atratulus

Lepomis macrochirus

Semotilus atromaculatus

Dorosoma cepedianum

Micropterus salmoides 
TABLE A.1 (Cont'd)

Common Name

Scientific Name

\section{FISH (Cont'd)}

Redbreast sunfish

Skipjack herring

White bass

White crappie

BIRDS

Black duck

Black vulture

Broad-winged hawk

Canada goose

Great blue heron

Mallard

Mourning dove

Quail

Red-tailed hawk

Ruffed grouse

Screech owl

Turkey vulture

Wood duck

\section{MAMMALS}

Beaver

Bobcat

Eastern cottontail rabbit

Eastern gray squirrel

Golden mouse

Gray fox

Longtail weasel

Mink

Muskrat

Raccoon

Red fox

Striped skunk

White-footed mouse

White-tailed deer

Woodchuck
Lepomis auritus

Alosa chrysochloris

Morone chrysops

Pomoxis annularis

Anas rubripes

Coragyps atratus

Buteo platypterus

Branta canadensis

Ardea herodias

Anas platyrhynchos

Zenaida macroura

Colinus virginiana

Buteo jamaicensis

Bonasa umbellus

Otus asio

Cathartes aura

Aix sponsa

Castor canadensis

Lynx rufus

Sylvilagus floridanus

Sciurus carolinensis

Peromyscus nuttalli

Urocyon cinereoargenteus

Mustela frenata

Mustela vison

Ondatra zibethica

Procyon lotor

Vulpes fulva

Mephitis mephitis

Peromyscus leucopus

Odocoileus virginianus

Marmota monax 


\section{Appendix B}

National Register of Historic Places: Sites in Study Area 


\section{Appendix B \\ National Register of Historic Places: Sites in Study Area}

The followirig sites are recorded in the National Register of Historic Places for Anderson, Knox, Loudon, Morgan, and Roane counties in Tennessee, as of November 1989 (Saylor et al. 1990).

\section{ANDERSON COUNTY}

Lake City. Edwards-Fowler House, 3.5 miles south of Lake City on Dutch Valley Rd. (5-29-75)

Nr,rris. Arnwine Cabin, State Route (SR) 61 (3-16-76)

Piorris. Norris District, Town of Norris on U.S. 441 (7-10-75)

\section{KNOX COUNTY}

Concord. Concord Village Historic District, Roughly bounded by Lakeridge and Third Drives, Spring St. and the Masonic Hall and Cemetery (10-22-87)

Concord. Russel, Avery, House, 11409 Kingston Pike (6-5-75)

Knoxville. Bleak House, 3148 Kingston Pike (11-8-84)

Knoxville. Blount, William, Mansion, 200 West Hill Ave. (10-15-66)

Knoxville. Boyd-Harvey House, Harvey Rd. (11-7-85)

Knoxville. Burwell Building Tennessee Theater, 600 South Gay St. (4-1-82)

Knoxville. Camp House, 1306 Broadway, NE (4-24-73)

Knoxville. Caswell-Taylor House, 803 North Fourth St. (8-1-86) RN

Knoxville. Commerce Avenue Fire Hall, 201-5 Commerce Ave. (1977) RN

Knoxville. Cowan, McClung and Company Building, 500-4 Gay St. (7-12-84)

Knoxville. Craighead-Jackson House, 1000 State St. (3-20-73)

Knoxville. Dulin, H.L., House, 3100 Kingston Pike (10-15-74)

Knoxville. Fire Staion No. 5, 419 Arthur St., NW (11-2-78)

Knoxville. Fort Sanders Historic District, Roughly bounded by White and Grand Aves. and 11 th and 19th Sts. (9-16-80)

Knoxville. Fourth and Gill Historic District, Roughly bounded by I-40 Broadway, Central, and Fifth Aves. (4-29-85)

Knoxville. Gay Street Commercial Historic District, Roughly along Gay St. from Summit Hill Dr. to Church Ave. (11-4-86)

Knoxville. General Building, 625 Market St. (3-8-88)

Knoxville. Gibbs, Nicholas, House, Emory Rd. (9-9-88)

Knoxville. Holston National Bank, 531 South Gay St. (10-2-79) 
Knoxville. Jackson Avenue Warehouse District, Jackson Ave. (4-11-73); now Southern Terminal District

Knoxville. Jackson Avenue Warehouse District Extension, 120-24 Jackson Ave. (3-10-75); now Southern Terminal District

Knoxville. Johnson, Andrew, Hotel, 912 South Gay St. (7-9-80)

Knoxville. Knollwood, 6411 Kingston Pike (5-12-75)

Knoxville. Knox County Courthouse, Main Ave. and Gay St. (4-24-73)

Knoxville. Knoxville Business College, 209 West Church St. (1-27-83)

Knoxville. Knoxville College Historic District, 901 College St., NW $(5-1-80)$

Knoxville. Knoxville Iron Foundry Complex-Nail Factory and Warehouse, 715 Western Ave., NW (3-25-82)

Knoxville. Knoxville Post Office, 501 Main St. (5-31-84)

Knoxville. Knoxville YMCA Building, 605 Clinch Ave. (11-17-83)

Knoxville. Lamar House Hotel, 803 Gay St., SW (12-4-75)

Knoxville. Lebanon-in the-Fork Presbyterian Church, Asbury Rd. (2-18-83) RN

Knoxville. Louisville and Nashville Freight Depot, 700 Western Ave., NW (3-25-82)

Knoxville. Loiusville and Nashville Passenger Station, 700 Western Ave., NW (3-25-82)

Knoxville. Mabry, Joseph Alexander, Jr., House, 1711 Dandridge Ave. (11-13-89)

Knoxville. Mall Building, 1-5 Market St. (8-26-82)

Knoxville. Marble Springs, S of Knoxville on Neubert Springs Rd. (5-6-71)

Knoxville. Market Square Commercial Historic District, Market Square Mall (12-20-84)

Knoxville. McCammon, Samuel, House, 1715 Riverside Dr. (3-1-84)

Knoxville. Mechanics Bank and Trust Company Building, 612 South Gay St. (1-27-83)

Knoxville. Mechanicsville Historic District, Off SR 62 (7-18-80)

Knoxville. Medical Arts Building, 603 Main St. (5-24-84)

Knoxville. Middlebrook, 4001 Middlebrook Pike (6-18-74)

Knoxville. New Salem United Methodist Church, 2417 Tipton Station Rd. (8-11-83)

Knoxville. Old Knoxville City Hall, Summit Hill Dr. (5-31-72)

Knoxville. Old Post Office Building, Clinch and Market Sts. (3-20-73)

Knoxville. Ossoli Circle Clubhouse, 2511 West Cumberland Ave. (3-21-85)

Knoxville. Park City Junior High School, 523 Bertrand St. (6-30-83)

Knoxville. Park, James, House, 422 West Cumberland Ave. (10-18-72)

Knoxville. Southern Terminal and Warehouse Historic District, Bounded by Depot, Central, Sullivan, Vine, and Gay Sts. (11-18-85)

Knoxville. St. John s Lutheran Church, 544 Broadway, NW (4-4-85)

Knoxville. Talahi Improvements, Off U.S. 129 (12-26-79)

Knoxville. Trinity Methodist Episcopal Church, 416 Lovenia Ave. (8-26-82)

Knoxville. U.T. Agriculture Farm Mound, Neyland Dr. (3-30-78)

Knoxville. Westwcod, 3425 Kingston Pike (11-8-84) 
Knoxville. Williams, Col. John, House, 2325 Dandridge Ave. (12-3-80)

Knoxville. Zeigler, Isaac, House, 712 North Fourth Ave. (8-1-86) RN

Knoxville vicinity. Buffat, Alfred, Homestead, 1 mile $\mathrm{N}$ of Knoxville on Love Creek Rd. (4-1-75)

Knoxville vicinity. Ebenezer Mill, Ebenezer Rd. (6-25-87)

Knoxville vicinity. Ramsey House, SE of Knoxville on Thorngrove Pike (12-23-69)

Knoxville vicinity. Riverdale Mill, Wayland Rd. and Thorngrove Pike (3-13-87)

Knoxville vicinity. Statesview, $\sim 10$ miles SW of Knoxville off U.S. 70 (4-24-73)

Mascot. Chesterfield, N of Mascot off Old Ruteledge Pike (11-16-77)

\section{LOUDON COUNTY}

Greenback. McCollum Farm, SW of Greenback on Morganton Rd. (4-15-78) Greenback. National Campground, SR 1 (1-7-72)

Greenback vicinity. Griffitts, William H., House, Jackson Ferry-Greenback Rd. (3-29-89)

Lenoir. Lenoir Cotton Mill, Depot St. (6-18-75)

Lenoir City. Bussell Island Site, S of Lenoir City (3-29-78)

Lenoir City. Lewir City Company, Depot St. (3-19-82)

Loudon. Blair s Ferry Storehouse, 800 Main St. (7-14-77)

Loudon. Bowman House, E of Loudon on Little River Rd. (7-8-70)

Loudon. Cannon-Calloway House, W of Loudon off U.S. 11 (7-8-70)

Loudon. Carmichael Inn, Off U.s. 11 (7-8-70) RN

Loudon. Cumberland Presbyterian Church of Loudon, College St. (4-15-82)

Loudon. Lenoir, Albert, House, W of Loudon on Ri /er Rd. (SR 72) (4-11-73)

Loudon. Loudon County Courthouse, Grove and Nulberry Sts. (5-28-75)

Loudon. Mason Place, 600 Commercial St. (11-27-89)

Loudon. Robinson Mill, SR 72 (4-5-84)

Loudon. Wilson, Orme, and Company Storehouse, Hackberry St. (2-2-80)

\section{MORGAN COUNTY}

Rugby. Rugby Colony, SR 52 (4-26-72)

\section{ROANE COUNTY}

Harriman. Harriman City Hall, Roane and Walden Sts. (9-11-75)

Harriman. Roane Street Commercial District, Roughly Roane St. between Morgan and Crescent Aves., NW (6-29-89)

Kingston. Morgan, Col. Gideon, House, 149 Kentucky St. (1-27-83)

Kingston. Roane County Courthouse, Kentucky Ave. (7-14-71) 
Kingston vicinity. Southwest Point, 1 mile SW of Kingston (7-31-72)

Oak Ridge. X-10 Reactor Oak Ridge National Laboratory, Oak Ridge National Laboratory (10-15-66)

Oliver Springs. Colonial Hall, Spring and Main Sts. (9-11-75) 

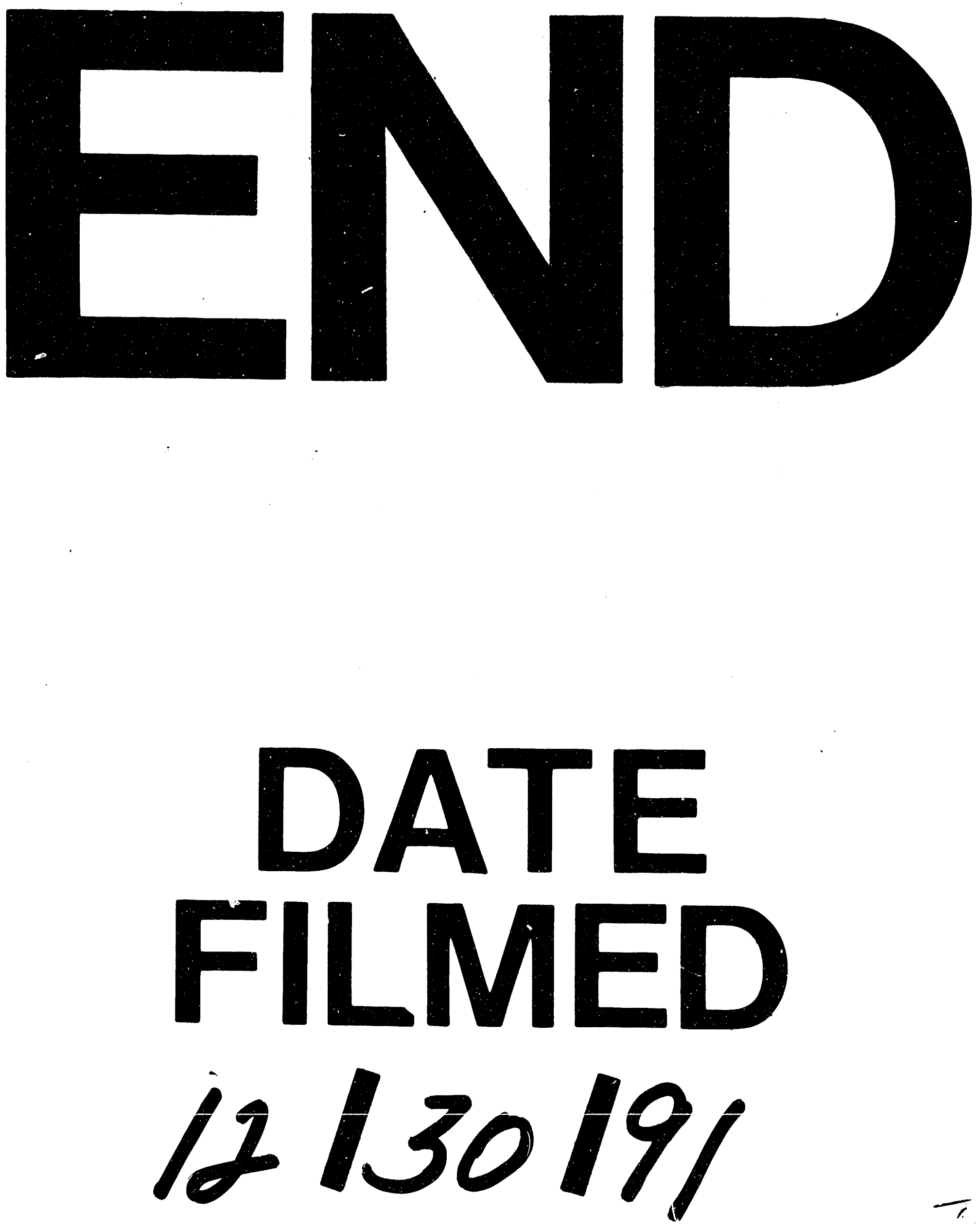
